\title{
Evolution of Banking in India
}

\author{
${ }^{1}$ Rimple Saini, Research Scholar, ${ }^{2}$ Dr.S.L.Lodha \\ ${ }^{1}$ MJRP University, Jaipur,Rajasthan,India \\ ${ }^{2}$ Former Associate Professor Economics, Rajasthan University Jaipur and \\ MDS University Ajmer, Rajasthan, India
}

\section{Introduction}

1.1 The story of banking has much in common, as it evolved with the moneylenders accepting deposits and issuing receipts in their place. The existence of professional banking in India could be traced to the $500 \mathrm{BC}$. Kautilya's Arthashastra, dating back to $400 \mathrm{BC}$ contained references to creditors, lenders and lending rates. Banking was fairly varied and catered to the credit needs of the trade, commerce, agriculture as well as individuals in the economy.An extensive network of Indian banking houses existed in the country connecting all cities/towns that were of commercial importance. They had their own inland bills of exchange or hundis whichwere the major forms of transactions between Indian bankers and their trans-regional connections. $\stackrel{2}{2}$ Banking practices in force in India were vastly different from the European counterparts. The dishonoring of hundis was a rare occurrence. Most banking worked on mutual trust, confidence and without securities and facilities that were considered essential by British bankers.Banking regulation also had a rich tradition and evolved along with banking in India. In fact, the classic 'Arthashastra' also had norms for banks going into liquidation. If anyone became bankrupt, debts owed to the State had priority over other creditors.

1.2 The early years of independence (1947 to 1967) posed several challenges with an underdeveloped economy presenting the classic case of market failure in the rural sector, where information asymmetry limited the foray of banks. Further, the non-availability of adequate assets made it difficult for people to approach banks. With the transfer of undertaking of Imperial Bank of India to State Bank of India (SBI) and its subsequent massive expansion in the under-banked and unbanked centres spread institutional credit into regions which were unbanked heretofore. Proactive measures like credit guarantee and deposit insurance promoted the spread of credit and savings habits to the rural areas. There were, however, problems of connected lending as many of the banks were under the control of business houses.

1.3 The period from 1967 to 1991 was characterised by major developments, viz., social control on banks in 1967 and nationalisation of 14 banks in 1969 and six more in 1980. The nationalisation of banks was an attempt to use the scarce resources of the banking system for the purpose of planned development. The task of maintaining a large number of small accounts was not profitable for the banks as a result of which they had limited lending in the rural sector. The problem of lopsided distribution of banks and the lack of explicit articulation of the need to channel credit to certain priority sectors was sought to be achieved first by social control on banks and then by the nationalisation of banks in 1969 and 1980. The Lead Bank Scheme provided the blue-print of further bank branch expansion. The course of evolution of the banking sector in India since 1969 has been dominated by the nationalisation of banks. This period was characterised by rapid branch expansion that helped to draw the channels of monetary transmission far and wide across the country. The share of unorganised credit fell sharply and the economy seemed to come out of the low level of equilibrium trap. However, the stipulations that made this possible and helped spread institutional credit and nurture the financial system, also led to distortions in the process. The administered interest rates and the burden of directed lending constrained the banking sector significantly. There was very little operational flexibility for the commercial banks. Profitability occupied a back seat. Banks also suffered from poor governance. The financial sector became the 'Achilles heel' of the economy (Rangarajan, 1998). Fortunately, for the Indian economy, quick action was taken to address these issues.

1.4 The period beginning from the early 1990s witnessed the transformation of the banking sector as a result of financial sector reforms that were introduced as a part of structural reforms initiated in 1991. The reform process in the financial sector was undertaken with the prime objective of having a strong and resilient banking system. The progress that was achieved in the areas of strengthening the regulatory and supervisory norms ushered in greater accountability and market discipline amongst the participants. The Reserve Bank made sustained efforts towards adoption of international benchmarks in a gradual manner, as appropriate to the Indian conditions, in various areas such as prudential norms, risk management, supervision, corporate governance and transparency and disclosures. The reform process helped in taking the management of the banking sector to the level, where the Reserve Bank ceased to micro-manage commercial banks and focused largely on the macro goals. The focus on deregulation and liberalisation coupled with enhanced responsibilities for banks made the banking sector resilient and capable of facing several newer global challenges. 
1.5 In the above backdrop, this chapter traces the history of the banking sector in India. Although the focus is on its post-independence history, it starts with a broad brush sketch of the early years of banking. The chapter is organised in six sections. Section II narrates the story as it unfolded historically in the pre-independence period. Section III outlines the major developments in the banking sector from 1947 to 1967. Section IV deals at length with the major developments in the period from 1967 to 1991. Developments from 1991 and onwards are covered in Section V. Section VI sums up the main points of discussions.

\section{Beginning of Banking in India}

\section{The Early Phase Of Banking In India -UP TO 1947}

1.6 The phase leading up to independence laid the foundations of the Indian banking system. The beginning of commercial banking of the joint stock variety that prevailed elsewhere in the world could be traced back to the early 18th century. The western variety of joint stock banking was brought to India by the English Agency houses of Calcutta and Bombay (now Kolkata and Mumbai). The first bank of a joint stock variety was Bank of Bombay, established in 1720 in Bombay ${ }^{4}$. This was followed by Bank of Hindustan in Calcutta, which was established in 1770 by an agency house..$^{\frac{5}{2}}$ This agency house, and hence the bank was closed down in 1832 . The General Bank of Bengal and Bihar, which came into existence in 1773, after a proposal by Governor (later Governor General) Warren Hastings, proved to be a short lived experiment ${ }^{\underline{6}}$. Trade was concentrated in Calcutta after the growth of East India Company's trading and administration. With this grew the requirement for modern banking services, uniform currency to finance foreign trade and remittances by British army personnel and civil servants. The first 'Presidency bank' was the Bank of Bengal established in Calcutta on June 2, 1806 with a capital of Rs.50 lakh. The Government subscribed to 20 per cent of its share capital and shared the privilege of appointing directors with voting rights. The bank had the task of discounting the Treasury Bills to provide accommodation to the Government. The bank was given powers to issue notes in 1823. The Bank of Bombay was the second Presidency bank set up in 1840 with a capital of Rs.52 lakh, and the Bank of Madras the third Presidency bank established in July 1843 with a capital of Rs.30 lakh. They were known as Presidency banks as they were set up in the three Presidencies that were the units of administrative jurisdiction in the country for the East India Company. The Presidency banks were governed by Royal Charters. The Presidency banks issued currency notes until the enactment of the Paper Currency Act, 1861, when this right to issue currency notes by the Presidency banks was abolished and that function was entrusted to the Government.

1.7 The first formal regulation for banks was perhaps the enactment of the Companies Act in 1850. This Act, based on a similar Act in Great Britain in 1844, stipulated unlimited liability for banking and insurance companies until 1860, as elsewhere in the world. In 1860, the Indian law permitted the principle of limited liability following such measures in Britain. Limited liability led to an increase in the number of banking companies during this period. With the collapse of the Bank of Bombay, the New Bank of Bombay was established in January 1868.The Presidency Bank Act, which came into existence in 1876, brought the three Presidency banks under a common statute and imposed some restrictions on their business. It prohibited them from dealing with risky business of foreign bills and borrowing abroad for lending more than 6 months, among others. In terms of Act XI of 1876, the Government of India decided on strict enforcement of the charter and the periodic inspection of the books of these banks. The proprietary connection of the Government was, however, terminated, though the banks continued to hold charge of the public debt offices in the three presidency towns, and the custody of a part of the Government balances. bank established in July 1843 with a capital of Rs.30 lakh. They were known as Presidency banks as they were set up in the three Presidencies that were the units of administrative jurisdiction in the country for the East India Company. The Presidency banks were governed by Royal Charters. The Presidency banks issued currency notes until the enactment of the Paper Currency Act, 1861, when this right to issue currency notes by the Presidency banks was abolished and that function was entrusted to the Government.

\section{Finance}

The Act also stipulated the creation of Reserve Treasuries at Calcutta, Bombay and Madras into which sums above the specified minimum balances promised to the presidency banks, were to be lodged only at their head offices. The Government could lend to the presidency banks from such Reserve Treasuries. This Act enabled the Government to enforce some stringent measures such as periodic inspection of the books of these banks. The major banks were organised as private shareholding companies with the majority shareholders being Europeans.

1.8 The first Indian owned bank was the Allahabad Bank set up in Allahabad in 1865, the second, Punjab National Bank was set up in 1895 in Lahore, and the third, Bank of India was set up in 1906 in Mumbai. All these banks were founded under private ownership. The Swadeshi Movement of 1906 provided a great impetus to joint stock banks of Indian ownership and many more Indian commercial banks such as Central Bank of India, Bank of Baroda, Canara Bank, Indian Bank, and Bank of Mysore were established between 1906 and 
1913. By the end of December 1913, the total number of reporting commercial banks in the country reached 56 comprising 3 Presidency banks, 18 Class 'A' banks (with capital of greater than Rs. 5 lakh), 23 Class 'B' banks (with capital of Rs.1 lakh to 5 lakh) and 12 exchange banks. Exchange banks were foreign owned banks that engaged mainly in foreign exchange business in terms of foreign bills of exchange and foreign remittances for travel and trade. Class A and B were joint stock banks. The banking sector during this period, however, was dominated by the Presidency banks as was reflected in paid-up capital and deposits (Table 3.1).

\section{Table 3.1: Number of Banks, Capital and Deposits}

\begin{tabular}{|c|c|c|c|c|c|c|c|c|c|c|c|c|c|c|}
\hline \multirow{3}{*}{ End- } & \multirow{2}{*}{\multicolumn{5}{|c|}{ Number of Reporing Commercial Banks }} & \multirow{2}{*}{\multicolumn{4}{|c|}{ Paid-up Capital and Reserves }} & \multicolumn{5}{|c|}{ (Anrount in Rs Lakh) } \\
\hline & & & & & & & & & & & $\mathrm{De}$ & posits & & \\
\hline & $\begin{array}{l}\text { Presidencyl } \\
\text { Imperial } \\
\text { Banice }\end{array}$ & Class & $\begin{array}{r}\text { Exchange } \\
\text { Bank }\end{array}$ & $\begin{array}{c}\text { Class } \\
\text { B" }\end{array}$ & Totai & $\begin{array}{l}\text { Presisencys } \\
\text { Inperial } \\
\text { Bankg }\end{array}$ & $\begin{array}{c}\text { Class } \\
A^{\prime}\end{array}$ & $\begin{array}{c}\text { Class } \\
\text { B" }\end{array}$ & Total & $\begin{array}{l}\text { Presidencyl } \\
\text { Imperial } \\
\text { Banke }\end{array}$ & $\begin{array}{c}\text { Class } \\
A^{*}\end{array}$ & $\begin{array}{c}\text { Exchange } \\
\text { Bank }\end{array}$ & $\begin{array}{c}\text { Class } \\
\text { B" }\end{array}$ & Tota \\
\hline 1870 & 3 & 2 & 3 & - & 8 & 362 & 12 & - & 374 & 1,197 & 14 & 52 & - & 1.263 \\
\hline 1880 & 3 & 3 & 4 & - & 10 & 405 & 21 & - & 428 & 1,140 & 63 & 345 & - & 1.543 \\
\hline 1890 & 3 & 5 & 5 & - & 13 & 48 & 51 & - & 400 & 1.836 & 271 & 754 & - & 2.801 \\
\hline 1800 & 3 & 9 & 8 & - & 20 & 560 & 128 & - & ege & 1,568 & 808 & 1,050 & - & 3,427 \\
\hline 1910 & 3 & 16 & 11 & - & 30 & 001 & 376 & - & 1,067 & 3.654 & 2,560 & 2470 & - & 8.600 \\
\hline 1913 & 3 & 18 & 12 & 23 & 50 & 748 & 304 & $\#$ & 1,112 & 4,236 & 2.259 & 3.104 & 151 & 9,750 \\
\hline 1020 & 3 & 25 & 15 & 33 & 76 & 753 & 1,000 & 81 & 1,027 & 8.020 & 7,115 & 7.451 & 233 & 23,458 \\
\hline 1930 & 1 & 31 & 18 & 57 & 107 & 1,115 & 1,190 & 141 & 2,440 & 6.397 & 6,320 & 6.811 & 439 & 21,973 \\
\hline 1934 & $i$ & 36 & 17 & eq & 123 & 1,128 & 1,267 & 149 & 2,544 & 8.100 & 7,677 & 7,140 & 511 & 23,426 \\
\hline \multicolumn{15}{|c|}{$\begin{array}{l}\text { : Trree presidency banks were amalgamated into a singe bank ie, imperial Bank of Incia in } 1921 . \\
\text { : Banks with captal and reserves of Rs. } 5 \text { lakh and over. } \\
\text { : Banks with captal and reserves over Rs.1 lakh and up to Rs.5 lakh. } \\
\text { Source : Statstical Tables Relating to Banks in inda, various issues. }\end{array}$} \\
\hline
\end{tabular}

1.9 The Swadeshi Movement also provided impetus to the co-operative credit movement and led to the establishment of a number of agricultural credit societies and a few urban co-operatives. The evolution of cooperative banking movement in India could be traced to the last decade of the 19th Century. The late Shri Vithal L Kavthekar pioneered the urban co-operative credit movement in the year 1889 in the then princely State of Baroda. ${ }^{7}$ The first registered urban co-operative credit society was the Conjeevaram Urban Co-operative Bank, organised in Conjeevaram, in the then Madras Presidency. The idea of setting up of such a co-operative was inspired by the success of urban co-operative credit institutions in Germany and Italy. The second urban cooperative bank was the Peoples' Co-operative Society in 1905 in Bangalore city in the princely State of Mysore. The joint stock banks catered mainly to industry and commerce. Their inability to appreciate and cater to the needs of clientele with limited means effectively drove borrowers to moneylenders and similar agencies for loans at exorbitant rates of interest - this situation was the prime mover for non-agricultural credit co-operatives coming into being in India. The main objectives of such co-operatives were to meet the banking and credit requirements of people with smaller means to protect them from exploitation. Thus, the emergence of urban cooperative banks' was the result of local response to an enabling legislative environment, unlike the rural cooperative movement that was largely State-driven (Thorat, 2006).

1.10 After the early recognition of the role of the co-operatives, continuous official attention was paid to the provision of rural credit. A new Act was passed in 1912 giving legal recognition to credit societies and the like. The Maclagan Committee, set up to review the performance of co-operatives in India and to suggest measures to strengthen them, issued a report in 1915 advocating the establishment of provincial cooperative banks. It observed that the 602 urban cooperative credit societies constituted a meager 4.4 per cent of the 13,745 agricultural credit societies. The Committee endorsed the view that the urban cooperative societies were eminently suited to cater to the needs of lower and middle-income strata of society and such institutions would inculcate banking habits among middle classes. Apart from commercial and co-operative banks, several other types of banks existed in India. This was because the term "bank" was an omnibus term and was used by the entities, which, strictly speaking, were not banks. These included loan companies, indigenous bankers and nidhis some of which were registered under the Companies Act, 1913. Although very little information was available about such banks, their number was believed to be very large. Even the number of registered entities was enormous. Many doubtful companies registered themselves as banks and figured in the statistics of bank failures. Consequently, it was difficult to define in strict legal terms the scope of organised banking, particularly in the period before 1913 (Chandavarkar, 2005).

\section{World War I and its Impact on Banking in India}

1.11 The World War I years (1913 to 1918) were indeed difficult years for the world economy. The alarming inflationary situation that had developed as a result of war financing and concentration on the war led to other problems like neglect of agriculture and consumers. Most activity during the war period was concentrated in urban areas. This further tilted the already adverse urban-rural balance. Rural areas lacked access to organised banking and this led to almost complete dependence of farmers on moneylenders who charged exorbitant rates 
of interest. During the war period, a number of banks failed. Some banks that failed had combined trading functions with banking functions. More importantly, several of the banks that failed had a low capital base. For instance, average capital of failed banks in 1913 was Rs.2.9 lakh as against the average capital of Rs.12 lakh for the category of Class A and B banks. The crisis had begun before the World War I, but accentuated during it (Table 3.2).

Table 3.2: Bank Failures in India - 1913 to 1921

\begin{tabular}{|c|c|c|c|c|}
\hline $\begin{array}{l}\text { Year } \\
\text { (January- } \\
\text { December) }\end{array}$ & $\begin{array}{r}\text { Number of } \\
\text { Banks } \\
\text { Failed }\end{array}$ & $\begin{array}{l}\text { Paid-up } \\
\text { Capital of } \\
\text { Failed } \\
\text { Banks } \\
\text { (Rs. DOO) }\end{array}$ & $\begin{array}{r}\text { Average } \\
\text { paid-up } \\
\text { capital of } \\
\text { Faled } \\
\text { Banks } \\
\text { (R.' 'ODO) }\end{array}$ & $\begin{array}{r}\text { Average } \\
\text { paid-up } \\
\text { capital of } \\
\text { Reporting } \\
\text { Banks } \\
\text { in Category } \\
\text { A \& B } \\
\text { (Rs. DOO) }\end{array}$ \\
\hline 1 & 2 & 3 & 4 & 5 \\
\hline 1913 & 12 & 3514 & 283 & 1152 \\
\hline 1914 & 42 & 10902 & 260 & 1195 \\
\hline 1815 & 11 & 451 & 41 & 1190 \\
\hline 1816 & 13 & 423 & 33 & 1170 \\
\hline 1817 & 9 & 2526 & 281 & 1315 \\
\hline 1918 & 7 & 146 & 21 & 1433 \\
\hline 1819 & 4 & 403 & 101 & 1585 \\
\hline 1820 & 3 & 725 & 242 & 1675 \\
\hline 1921 & 7 & 125 & 18 & 1901 \\
\hline $\begin{array}{l}\text { Note }: C \\
\text { Source : } B\end{array}$ & \multicolumn{4}{|c|}{$\begin{array}{c}\text { : Category A : Banks with capital and reserves of Rs. } 5 \text { lakh and } \\
\text { over. } \\
\text { Category B = Banks with capital and reserves of over Rs. } 1 \text { lakh } \\
\text { and up to Rs.5 lakh. } \\
\text { : Banking and Monetary Statistics of India. RBI, } 1854 .\end{array}$} \\
\hline
\end{tabular}

1.12 In retrospect, bank failures in India were attributed by scholars and committees, in a large measure, to individual imprudence and mismanagement, fraudulent manipulation by directors and managers; and incompetence and inexperience. Many banks had granted a large amount of unsecured advances to directors and their companies. The absence of adequate regulatory safeguards made it easy for directors and managers to mislead depositors/shareholders. It underscored the need for suitable machinery for regulation of commercial banking in India. Several exchange banks also failed during this period mainly due to external reasons relating to their parent countries/companies. The mor tality rate among exchange banks was disconcertingly high. The commonest causes of failure of exchange banks were global, the highs and lows of the World Wars and inflation.

1.13 The presidency banks were amalgamated into a single bank, the Imperial Bank of India, in $1921 . \underline{8}$ The Imperial Bank of India was further reconstituted with the merger of a number of banks belonging to old princely states such as Jaipur, Mysore, Patiala and Jodhpur. The Imperial Bank of India also functioned as a central bank prior to the establishment of the Reserve Bank in 1935. Thus, during this phase, the Imperial Bank of India performed three set of functions, viz., commercial banking, central banking and the banker to the government.By 1930, the number of commercial banks increased to 107 with the Imperial Bank of India still dominating the Indian banking sector (refer Table 3.1). Besides, at end-March 1929, 158 co-operative banks also existed. The number of co-operative banks rose sharply (more than doubled) between 1922-23 to 1928-29 (Table 3.3). Although greater than commercial banks in number, the size of deposits of co-operative banks was much smaller.

Table 3.3: Number of Co-operative Banks

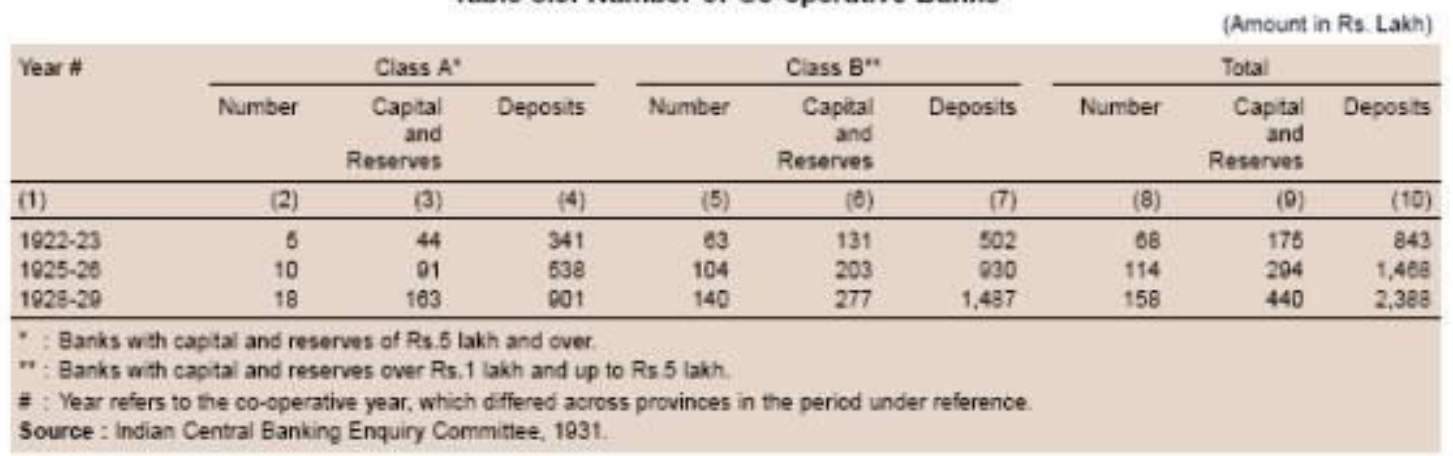

1.14 In 1930, the banking system, in all, comprised 1258 banking institutions registered under the Indian Companies Act, 1913 (Table 3.4). 
Table 3.4: Province-wise Distribution of Banks in India - $1930^{*}$

\begin{tabular}{|c|c|c|}
\hline No. & State & No of Reporting Banks \\
\hline 1. & Madras & 167 \\
\hline 2. & Bombay & 30 \\
\hline 3. & Bengal & 918 \\
\hline 4. & United Provinces of Agra and Oudh & 33 \\
\hline 5. & Punjab & 28 \\
\hline 6. & Burma & 4 \\
\hline 7. & Bihar and Orissa & 18 \\
\hline 8. & Central Provinces and Berar & 3 \\
\hline 9. & Assam & 51 \\
\hline 10. & N.W.F. Province & 1 \\
\hline \multirow[t]{2}{*}{11.} & Delhi Province & 3 \\
\hline & Total & 1258 \\
\hline
\end{tabular}

1.15 The world economy was gripped by the Great Depression during the period from 1928 to 1934 . This also had an impact on the Indian banking industry with the number of banks failing rising sharply due to their loans going bad. The capital of banks that failed, on an average, was lower than the average size of the capital of reporting banks in categories $\mathrm{A}$ and $\mathrm{B}$, indicating that the banks that failed were small (Table 3.5).

\begin{tabular}{|c|c|c|c|c|}
\hline $\begin{array}{l}\text { Yeor } \\
\text { (Januany- } \\
\text { December) }\end{array}$ & $\begin{array}{l}\text { Number of } \\
\text { Banss } \\
\text { Faled }\end{array}$ & $\begin{array}{l}\text { Pald-up } \\
\text { Captal of } \\
\text { Falied } \\
\text { Barks } \\
\text { (Ra, Doo) }\end{array}$ & $\begin{array}{l}\text { Average } \\
\text { pald-up } \\
\text { caplal of } \\
\text { Faled } \\
\text { Barks } \\
\text { (Rs. tudo) }\end{array}$ & $\begin{array}{r}\text { Average } \\
\text { padrup } \\
\text { capital of } \\
\text { Reporting } \\
\text { Banka } \\
\text { in Categary } \\
\text { A } 2 \text { B } \\
\text { (Ra, DoO) }\end{array}$ \\
\hline 1 & 2 & 3 & 4 & 5 \\
\hline 1926 & 14 & 398 & 28 & 1017 \\
\hline 1927 & 16 & 311 & 19 & 1005 \\
\hline 1928 & 13 & 2312 & 178 & 1022 \\
\hline 1929 & 11 & 819 & 74 & 1105 \\
\hline 1930 & 12 & 4060 & 338 & 952 \\
\hline 1931 & 16 & 1506 & 84 & 964 \\
\hline 1932 & 24 & 809 & 34 & 1008 \\
\hline 1933 & 26 & 300 & 12 & 973 \\
\hline 1934 & 30 & 623 & 21 & 851 \\
\hline 1935 & 51 & 6596 & 129 & 861 \\
\hline
\end{tabular}

1.16 The Indian Central Banking Enquiry Committee, which was set up in 1929 to survey extensively the problems of Indian banking, observed that a central bank be established for the country and that a special Bank Act be enacted incorporating relevant provisions of the then existing Indian Companies Act (1913), and including new provisions relating to (i) organisation, (ii) management, (iii) audit and inspection, and (iv) liquidation and amalgamations. It also noted that the commercial banks played a negligible role in financing the requirements of agricultural production and cooperative credit.$^{2}$ Examining the credit requirements of the cultivator, it noted "his needs are satisfied, if at all, inadequately and at ruinous prices". In an agrarian economy, like India at that time, credit to agriculture was very crucial. Bank credit to agriculture was 0.3 per cent of GDP. Rural indebtedness in 1931 was estimated at Rs.900 crore, and it was increasing due to past indebtedness; extravagant social and ceremonial expenditure; high interest rates; recurring losses of cattle due to drought and disease; and lease of land at high prices and high rentals, resulting in the transfers of land from farmers to moneylenders.

1.17 The lack of spread of banking in rural areas and the consequent dependence of the rural population on informal sources was a major concern during these times. The problem of rural credit to some extent was also due to the fact that there was no distinction of the type of credit dispensed and the term for which it was granted. Bigger amounts of loans taken for investment purposes were unlikely to be paid off in a single season. It was reported that in many provinces, credit overdues to credit co-operative institutions constituted 60 to 70 per cent of the outstanding principal due. $\frac{10}{}$ 


\section{Setting up of the Reserve Bank and its Role}

1.18 The setting up of a central bank for the country was recommended by various committees that went into the causes of bank failures. ${ }^{11}$ It is interesting to note that many central banks were established specifically to take care of bank failures. For instance, the US Federal Reser ve, was established in 1913 pr imarily against the background of recurrent banking crises. It was felt that the establishment of a central bank would bring in greater governance and integrate the loosely connected banking structure in the country. It was also believed that the establishment of a central bank as a separate entity that does not conduct ordinary banking business (like the Imperial Bank of India) was likely to have the stature to be able to deftly handle the central banking functions without the other joint stock banks feeling any rivalry towards it. $\stackrel{12}{ }$ Accordingly, the Reserve Bank of India Act 1934 was enacted paving the way for the setting up of the Reserve Bank of India. The issue of bank failures and the need for catering to the requirements of agriculture were the two prime reasons for the establishment of the Reserve Bank. The banking sector came under the purview of the Reserve Bank in 1935. At the time of setting up of the Reserve Bank, the joint stock banks constituted the largest share of the deposits held by the banking sector, followed by the Imperial Bank of India and exchange banks (Table 3.6).

Table 3.6: Number of Commercial Banks in India and Deposits with Them

\begin{tabular}{|c|c|c|c|c|c|c|c|c|}
\hline & & & & & & & (Amount in & ees crore) \\
\hline \multirow[t]{2}{*}{ End-December } & \multicolumn{2}{|c|}{ Imperial Bank of Inda } & \multicolumn{2}{|c|}{ Exchange Eanks } & \multicolumn{2}{|c|}{ Joln:Stock Banks } & \multicolumn{2}{|c|}{ Total - All Banks } \\
\hline & Number & Deposits & Number & Deposits & Number & Deposits & Number & Deposits \\
\hline 1 & 2 & 3 & 4 & 5 & 6 & 7 & 8 & 9 \\
\hline 1926 & 1 & $\begin{array}{r}80 \\
(37.4)\end{array}$ & 18 & $\begin{array}{r}72 \\
(33.3)\end{array}$ & 76 & $\begin{array}{r}63 \\
(29.4)\end{array}$ & 95 & 215 \\
\hline 1929 & 1 & $\begin{array}{r}79 \\
(37.3)\end{array}$ & 18 & $\begin{array}{r}67 \\
\{31.4\rangle\end{array}$ & 79 & $\begin{array}{r}65 \\
(31.2)\end{array}$ & 98 & 212 \\
\hline 1932 & 1 & $\begin{array}{r}75 \\
(33.6)\end{array}$ & 18 & $\begin{array}{r}73 \\
\langle 32.5\rangle\end{array}$ & 87 & $\begin{array}{r}76 \\
(33.9)\end{array}$ & 106 & 225 \\
\hline 1935 & 1 & $\begin{array}{r}79 \\
(32.3)^{2}\end{array}$ & 17 & $\begin{array}{r}76 \\
(31.1)\end{array}$ & 106 & $\begin{array}{r}90 \\
(36.7)\end{array}$ & 124 & 245 \\
\hline
\end{tabular}

1.19 The Reserve Bank of India Act, 1934 gave the Reserve Bank powers to regulate issue of bank notes, the custody of the commercial banks' cash reserves and the discretion of granting them accommodation. The preamble to the RBI Act set forth its functions as "to regulate the issue of bank notes and the keeping of reserves with a view to securing monetary stability in India and generally to operate the currency and credit system of the country to its advantage". The Reserve Bank's main functions could be classified into the following broad categories (a) to act as a banker to the Government; (b) to issue notes; (c) to act as a banker to other banks; and (d) to maintain the exchange ratio. The RBI Act had a limited control on banks although its obligations in each sphere were spelt out in clear terms. There was some amount of built-in flexibility as the Reserve Bank was vested with extra powers and maneuverability under extra-ordinary circumstances, that could be exercised only with the prior approval of the Governor General in Council or the Central Board of the Bank as might be prescribed in each case.

1.20 The Reserve Bank, as the lender-of-last-resort, had a crucial role in ensuring the liquidity of the short-term assets of commercial banks. The banking sector had adequate liquidity in the initial years because it had a facility of selling Government securities freely to the Reserve Bank. ${ }^{13}$ In 1935, banks were required to maintain cash reserves of 5 per cent of their demand liabilities and 2 per cent of their time liabilities on a daily basis. The task of managing the currency that was assigned to the Controller of Currency came to the Reserve Bank in March 1935 under Section 3 of the RBI Act, 1934. The provisions of the RBI Act also required the Reserve Bank to act as a banker's bank. In accordance with the general central banking practice, the operations of the Reserve Bank with the money market were to be largely conducted through the medium of member banks, viz., the 'scheduled' banks and the provincial co-operative banks.

The 'scheduled' banks were banks which were included in the Second Schedule to the RBI Act and those banks in British India that subsequently became eligible for inclusion in this Schedule by virtue of their paid-up capital and reserves being more than Rs.5 lakh in the aggregate. The power to include or exclude banks in or from the Schedule was vested with the Governor General in Council. The preamble of the Reserve Bank of India Act that was accepted had no reference to a 'gold standard currency' for British India unlike that envisaged in the initial preamble of the 1928 Bill. This change occurred due to the fluidity of the international monetary situation in the intervening period, following Great Britain's departure from the gold standard in September 1931.

1.21The central bank, if it is a supervisory authority must have sufficient powers to carry out its functions, such as audit and inspection to be able to detect and restrain unsound practices and suggest corrective measures like revoking or denying licences. However, the Reserve Bank in the earlier years did not have adequate powers of control or regulation. Commercial banks were governed by the Company Law applicable to ordinary nonbanking companies, and the permission of the Reserve Bank was not required even for setting up of a new bank. 
The period after setting up of the Reserve Bank saw increase in the number of reporting banks. The classification of banks was expanded to include the banks with smaller capital and reserve base. Class 'A' banks were divided into A1 and A2. Further, two new categories of banks, viz,. ' $\mathrm{C}$ ' and ' $\mathrm{D}$ ' were added to include the smaller banks. Banks with capital and reserves of greater than Rs.5 lakh and included in the second schedule to the RBI Act 1934 were classified as Class A1, while the remaining non-scheduled banks with capital and reserves of greater than Rs.5 lakh were classified as Class A2. The rest of the non-scheduled banks were classified according to their size; those with capital and reserves of greater than Rs.1 lakh and lower than Rs.5 lakh were classified as Class B; banks with capital and reserves of greater than Rs.50,000 and up to Rs.1 lakh were classified as Class C; and those with capital and reserves of less than Rs.50,000 were classified as Class D. In 1940, the number of reporting banks was 654 (Table 3.7).

Table 3.7: Number of Reporting Banks and Deposits with them

\begin{tabular}{|c|c|c|c|c|c|c|c|c|c|c|c|c|c|c|c|c|}
\hline \multirow{3}{*}{$\begin{array}{l}\text { End- } \\
\text { Dec. }\end{array}$} & \multicolumn{8}{|c|}{ Nunber of Fesorting Conmercis Banks } & \multicolumn{8}{|c|}{ Depcata of Resoring Commenclal Barks } \\
\hline & $\begin{array}{c}\text { Imperial } \\
\text { Bank }\end{array}$ & $\begin{array}{r}\text { Cisas } \\
\text { A1 }\end{array}$ & $\begin{array}{c}\text { Exchanoe } \\
\text { Bank }\end{array}$ & $\begin{array}{cc}\mathrm{Coas} \\
\mathrm{A} 2\end{array}$ & $\begin{array}{r}\text { Class } \\
\text { s }\end{array}$ & $\begin{array}{r}\text { Class } \\
\text { C }\end{array}$ & $\begin{array}{r}\text { Cossa } \\
\text { D }\end{array}$ & \multirow[t]{2}{*}{ Total } & $\begin{array}{r}\text { Imoenial } \\
\text { Bark. }\end{array}$ & $\begin{array}{l}\text { Clags } \\
\text { A1 }\end{array}$ & $\begin{array}{r}\text { Exchange } \\
\text { Bark }\end{array}$ & $\begin{array}{l}\text { Class } \\
\mathrm{Az}_{2}\end{array}$ & $\begin{array}{r}\text { Class } \\
\text { a }\end{array}$ & $\begin{array}{r}\text { Class } \\
\text { C }\end{array}$ & $\begin{array}{r}\text { Class } \\
\text { D }\end{array}$ & \multirow[t]{2}{*}{ Totas } \\
\hline & \multicolumn{3}{|c|}{ Scheauled Banks } & \multicolumn{4}{|c|}{ Non-echeduled Banks } & & \multicolumn{3}{|c|}{ Pchedued Eanks } & \multicolumn{4}{|c|}{ Non-acheouled Banka } & \\
\hline 1936 & 1 & 27 & 19 & 9 & 71 & & & 127 & 7380 & 9007 & 7523 & 540 & 546 & & & 25496 \\
\hline 1940 & 1 & 41 & 20 & 17 & 122 & 121 & 332 & 654 & 9603 & 10611 & 8533 & 788 & 1104 & 286 & 272 & 31197 \\
\hline 1947 & 1 & 80 & 15 & 68 & 185 & 119 & 198 & 656 & 28659 & 62334 & 17331 & 5152 & 2947 & 455 & 300 & $1177 \pm 8$ \\
\hline 1950 & 1 & 74 & 15 & 73 & 189 & 123 & 124 & 600 & 23137 & 52270 & 17039 & 4659 & 2176 & 370 & 131 & $997 e z$ \\
\hline 1951 & 1 & 75 & 16 & 70 & 186 & 117 & 96 & 561 & 23091 & 51734 & 16304 & 4426 & 2079 & 367 & 105 & 99505 \\
\hline 1952 & + & 75 & 15 & 70 & 194 & 114 & 60 & 529 & 20595 & 50552 & 17522 & 3982 & 2023 & 303 & 68 & 95336 \\
\hline \multirow[t]{2}{*}{ Noto } & \multicolumn{16}{|c|}{ 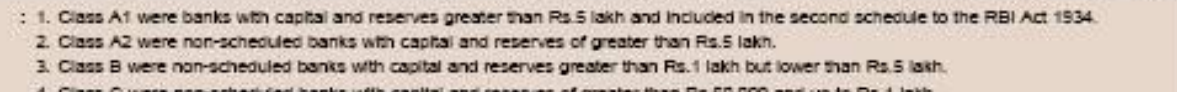 } \\
\hline & $\begin{array}{l}\text { 4. } 0 \\
5.0\end{array}$ & $198 \mathrm{D}$ we & ong & 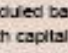 & rel rese & tot of & ase the & & $\begin{array}{l}\text { eater than } \\
000 \text {. }\end{array}$ & & & & & & & \\
\hline \multicolumn{17}{|c|}{ Souroo : Statistcal Tables Resatrg to Banks in inda, REI, various lseves. } \\
\hline
\end{tabular}

1.22 The underdeveloped nature of the economy and the lack of an appropriate regulatory framework posed a problem of effective regulation of a large number of small banks. The laisez faire policy that permitted free entry and exit had the virtues of free competition. However, benefits of such a policy are best reaped in a system that is characterised by 'perfect competition' unalloyed by market failures and imperfect markets. Indian financial markets at that stage, however, were certainly far from perfect. The free entry ushered in a very high growth of banking companies only to be marred by the problem of massive bank failures. Mushrooming growth of small banks in a scenario, where adequate regulation was not in place, led to various governance issues. The Reserve Bank's statute alone then did not provide for any detailed regulation of the commercial banking operations for ensuring sound banking practices. The submission of weekly returns made by scheduled banks under Section 42(2) of the Act was mainly intended to keep a watch over their compliance with the requirements regarding maintenance of cash reserves with the Reserve Bank. Inspection of banks by the Reserve Bank was visualised for the limited purpose of determining the eligibility of banks for inclusion or retention in the Second Schedule to the Act. Thus, apart from the limited scope of the Reserve Bank's powers of supervision and control over scheduled banks, a large number of small banking institutions, known as non-scheduled banks, lay entirely outside the purview of its control. When the Reserve Bank commenced operations, there were very few and relatively minor provisions in the Indian Companies Act, 1913, per taining to banking companies. This virtual absence of regulations for controlling the operations of commercial banks proved a serious handicap in the sphere of its regulatory functions over the banking system. There was ambiguity regarding the functioning of the smaller banks as there was no control on their internal governance or solvency.

1.23 Measures were taken to strengthen the regulation first by amending the Indian Companies Act in 1936. This amendment incorporated a separate chapter on provisions relating to banking companies. Prior to its enactment, banks were governed in all important matters such as incorporation, organisation and management, among others, by the Indian Companies Act, 1913 which applied commonly to banking as well as non-banking companies. There were only certain relatively innocuous provisions in the Companies Act 1913, which made a distinction between banks and other companies. The enactment of the Indian Companies (Amendment) Act, 1936 incorporated a separate chapter on provisions relating to banking companies, including minimum capital and cash reserve requirement and some operational guidelines. This amendment clearly stated that the banking companies were distinct from other companies.

1.24 In 1939, the Reserve Bank submitted to the Central Government its proposals for banking legislation in India. The important features of the proposals were to define banking in a simpler and clearer way than had been done in the Indian Companies Act, 1936. Second, the proposals sought to ensure that institutions calling themselves 'banks' started with sufficient minimum capital to enable them to operate on a scale large enough to make it possible for them to earn reasonable profits. Third, the proposals visualised certain moderate restrictions on bank investments in order to protect the depositors. Finally, an endeavour was made to expedite liquidation proceedings so that in the event of a bank failing, the depositors were paid off with the minimum delay and expense. However, the Government decided not to under take any comprehensive legislation during the war 
period when all the energies of the Government were inevitably concentrated on the war effort. Certain interim measures were taken to regulate and control by legislation certain issues that required immediate attention. After the war, the aspect of inadequate regulation was addressed partially by the promulgation of the RBI Companies (Inspection) Ordinance, 1946. New powers were given to the Reserve Bank under the Banking Companies (Restriction of Branches) Act, 1946 and the Banking Companies (Control) Ordinance, 1948. Most of the provisions in these enactments were subsequently embodied in the Banking Companies Act in 1949. This Act gave the Reserve Bank very comprehensive powers of supervision and control over the entire banking system as detailed in the subsequent section.

\section{The World War II and its Impact on Indian Banking}

1.25 The effects of the Second World War (1939 to 1944) on Indian banking were far-reaching. As India increasingly became a supply base for the Allied armies in the Middle East and South-East Asia, Government expenditure on defence and supplies to the Allies led to a rapid expansion of currency. As a result, the total money income of some sections of the community rose. This combined with a diversity of causes such as the difficulty in obtaining imports, the diversion of internal supplies to war needs, the control of the channels of investment and the distortion in the pattern of income distribution, among others, led to a rapid increase in the 'unspent margin' in the higher income groups, which, in turn, brought about a large pool of bank deposits. Such a situation encouraged the development of banking enterprises, apart from exchange banks, whose performance was driven mainly by external factors. The number of branches increased sharply between 1940 and 1945 and most of this branch expansion was accounted for by scheduled commercial banks (other than Imperial Bank of India and exchange banks) and non-scheduled banks (Table 3.8).

\section{Table 3.8: Number of Bank Branches: 1940-1945}

\begin{tabular}{|c|c|c|c|c|c|c|c|}
\hline End-Dec. & $\begin{array}{c}\text { Impertal } \\
\text { Bank of } \\
\text { incla }\end{array}$ & $\begin{array}{r}\text { Exchange } \\
\text { Banks }\end{array}$ & $\begin{array}{r}\text { Other } \\
\text { Scheduled } \\
\text { Banks }\end{array}$ & $\begin{array}{r}\text { Total } \\
\text { Scheduled } \\
\text { Banks }\end{array}$ & $\begin{array}{r}\text { Class 'A2' } \\
\text { Non-Scheduled } \\
\text { Banks" }\end{array}$ & $\begin{array}{l}\text { Class 'B' and 'C' } \\
\text { Non-Scheduled } \\
\text { Banks "- }\end{array}$ & $\begin{array}{r}\text { All Banks } \\
(5+6+7)\end{array}$ \\
\hline 1 & 2 & 3 & 4 & 5 & 6 & 7 & 8 \\
\hline 1940 & 383 & 87 & 844 & 1,314 & 105 & 545 & 1,964 \\
\hline 1941 & 393 & 84 & 937 & 1,414 & 204 & 678 & 2.296 \\
\hline 1942 & 392 & 84 & 971 & 1,447 & 263 & 869 & 2.579 \\
\hline 1943 & 399 & 84 & 1,395 & 1,878 & 400 & 996 & 3,274 \\
\hline 1945 & 428 & 77 & 2.451 & 2,956 & 811 & 1,434 & 5,201 \\
\hline
\end{tabular}

1.26 Several of the banks that expanded had very low capital. For instance, one bank with a capital of less than Rs.2 lakh opened more than 75 branches. The banking system that prevailed, therefore, was freer than the 'free banking that prevailed in the US around the civil war'. This was because even under the free banking there were some norms regarding entry level capital, and anyone meeting the minimum requirement of integrity and capital could receive a charter. In India, even these entry level requirements were not enforceable. The funds deposited by the public were often utilised to acquire control over non-banking companies by the purchase of their shares at highly inflated prices. Other conspicuous features of these small banks were the cross holding of shares between the banks and other companies in which the management was interested, large unsecured advances to persons connected with the management, advances against speculative shares when prices were very high and advances against immovable property which could not be recovered easily in times of need. Between 1936 and 1945, many small banks failed (Table 3.9).

Table 3.9: Failure of Banks - 1936-1945

\begin{tabular}{|c|c|c|c|c|}
\hline & & & \multicolumn{2}{|c|}{ (Amount in Rs. 000} \\
\hline $\begin{array}{l}\text { Year } \\
\text { (January- } \\
\text { Decentiber) }\end{array}$ & $\begin{array}{l}\text { No. of } \\
\text { Falled } \\
\text { Eanks }\end{array}$ & $\begin{array}{l}\text { Paid-up } \\
\text { Captal of } \\
\text { Falled } \\
\text { Banks }\end{array}$ & $\begin{array}{r}\text { Average } \\
\text { Pald-up } \\
\text { Capiltal of } \\
\text { Falled } \\
\text { Banks }\end{array}$ & $\begin{array}{r}\text { Average } \\
\text { Pald-up } \\
\text { Capital of } \\
\text { Reporting } \\
\text { Banis: }\end{array}$ \\
\hline 1 & 2 & 3 & 4 & 5 \\
\hline 1936 & 88 & 500 & 6 & 684 \\
\hline 1937 & 65 & 1152 & 18 & 552 \\
\hline 1938 & 73 & 3000 & 41 & 514 \\
\hline 1939 & 117 & 2491 & 21 & 162 \\
\hline 1940 & 107 & 2390 & 22 & 188 \\
\hline 1941 & 94 & 1239 & 13 & 281 \\
\hline 1942 & 50 & 1407 & 28 & 327 \\
\hline 1943 & 59 & 749 & 13 & 426 \\
\hline 1944 & 28 & 627 & 22 & 468 \\
\hline 1945 & 27 & 474 & 18 & 503 \\
\hline
\end{tabular}


1.27 Several banks in the process of expansion spread out thin, which increased the risk of failure. Interestingly, in spite of this wave of bank failures, there was very little contagion across the banking sector. This was because the Indian banking sector was underdeveloped and was loosely connected. This lack of integration kept the effect of bank failures fairly localised even when relatively larger banks failed. The resilience of the Indian banking system came to a large measure from the relative isolation of banks and lack of integration of the banking sector. Besides, slower communications in those years paradoxically saved it from a wide spread crisis (Chandavarkar, 2005).

1.28 To sum up, the period leading up to the independence was a difficult period for Indian banks. A large number of small banks sprang up with low capital base, although their exact number was not known. The organised sector consisted of the Imperial Bank of India, joint-stock banks (which included both joint stock English and Indian banks) and the exchange banks dealing in foreign exchange. During this period, a large number of banks also failed. This was due to several factors. This period saw the two world wars and the Great Depression of 1930. Although global factors contributed to bank failure in a large measure, several domestic factors were also at play. Low capital base, insufficient liquid assets and inter-connected lending were some of the major domestic factors. When the Reserve Bank was set up in 1935, the predominant concern was that of bank failures and of putting in place adequate safeguards in the form of appropriate banking regulation. Yet, even after more than twelve years after the establishment of the Reserve Bank, the issue of strengthening of the Reserve Bank through a separate legislation did not come through. The major concern was the existence of nonscheduled banks as they remained outside the purview of the Reserve Bank. Banking was more focused on urban areas and the credit requirements of agriculture and rural sectors were neglected. These issues were pertinent when the country attained independence.

\section{Banking In The Early Years Of independent India - 1947 TO 1967}

1.29 Independence made a large difference to many spheres of economic activity and banking was one of the most crucial areas where a phenomenal transformation took place. On the eve of

independence, several difficulties plagued the banking system as noted by the then Governor C.D. Deshmukh:"The difficulty of the task of the Reserve Bank of India in dealing with the banking system in the country does not lie in the multiplicity of banking units alone. It is aggravated by its diversity and range. There can be no standard treatment in practice although in theory the same law governs all'. .4

1.30 At the time of independence, the banking structure was dominated by the domestic scheduled commercial banks. Non-scheduled banks, though large in number, constituted a small share of the banking sector (Table $\underline{3.10})$.

\begin{tabular}{|c|c|c|}
\hline Category of Reporting Banks & Number & $\begin{array}{r}\text { Deposits } \\
\text { (Rs. crore) }\end{array}$ \\
\hline 1 & 2 & 3 \\
\hline A. Scheduled Banks & 97 & 1090 \\
\hline Imperlal Bank & 1 & $\begin{array}{r}287 \\
(22.8)\end{array}$ \\
\hline Other Banks (A1 Banks) & 81 & $\begin{array}{r}623 \\
(49.4)\end{array}$ \\
\hline Exchange Banks" & 15 & $\begin{array}{r}180 \\
(14.3)\end{array}$ \\
\hline B. Non-Scheduled Banks & 557 & $\begin{array}{r}89 \\
(7.1)\end{array}$ \\
\hline 1) Cla55 A2 & 65 & 52 \\
\hline 11) Class B & 185 & 29 \\
\hline iii) Clas5 C & 119 & \\
\hline iv) Class D & 188 & \\
\hline C. Co-operattve Banks & 395 & $\begin{array}{r}82 \\
(6.5)\end{array}$ \\
\hline D. All Banks - Total & 1034 & 1261 \\
\hline \multicolumn{3}{|c|}{ 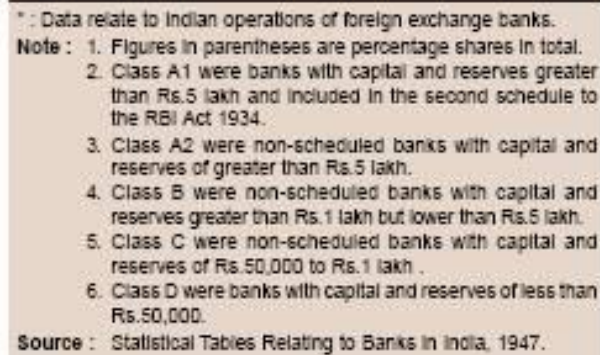 } \\
\hline
\end{tabular}

1.31 Commercial banks had a regional focus, as alluded to earlier. West Bengal had the largest number of scheduled commercial banks, followed by Madras and Bombay. As regards the non-scheduled banks, Madras 
had the largest number, followed by a distant second and third by West Bengal and Bombay, respective

\begin{tabular}{|c|c|c|c|c|c|c|}
\hline \multirow{3}{*}{ State } & \multicolumn{6}{|c|}{ (Amount in Rupees crore } \\
\hline & \multicolumn{2}{|c|}{$\begin{array}{l}\text { Scheduled } \\
\text { Banks }\end{array}$} & \multicolumn{2}{|c|}{$\begin{array}{c}\text { Non-scheduled } \\
\text { Banks }\end{array}$} & \multicolumn{2}{|c|}{ Total } \\
\hline & \multicolumn{2}{|c|}{ No of Paid-up } & \multicolumn{2}{|c|}{ No. of Paid-up } & \multicolumn{2}{|c|}{ No of Pald-up } \\
\hline 1 & 2 & 3 & 4 & 5 & 6 & 7 \\
\hline Assam & 1 & 1 & 14 & 2 & 15 & 3 \\
\hline Blnar & 2 & 6 & 10 & 1 & 12 & 6 \\
\hline Bombay & 13 & 71 & 27 & 7 & 40 & 78 \\
\hline Madras & 14 & 24 & 186 & 20 & 200 & 45 \\
\hline Wiest Bengal & 22 & 146 & 84 & 12 & 106 & 158 \\
\hline Deln! & 5 & 32 & 3 & 1 & 8 & 33 \\
\hline East Punjab & 7 & 14 & 20 & 5 & 27 & 19 \\
\hline CP and Berar & 2 & 4 & 3 & 1 & 5 & 5 \\
\hline Unted Provinces & 5 & 15 & 20 & 2 & 25 & 17 \\
\hline Ajmer Merwara & 0 & 0 & 1 & - & 1 & - \\
\hline Indian States & 11 & 53 & 187 & 38 & 198 & 91 \\
\hline Total & 82 & 365 & 555 & 89 & 637 & 454 \\
\hline
\end{tabular}

\section{Bank Failures and Liquidation/Consolidation of Smaller Banks}

1.32 The partition of the country hurt the domestic economy, and the banking sector was no different. Of the 84 banks operating in the country in the organised sector before partition, two banks were left in Pakistan. Many of the remaining banks in two States of Punjab and West Bengal were deeply affected. In 1947, 38 banks failed, of which, 17 were in West Bengal alone, having total paid-up capital of Rs.18 lakh. The paid-up capital of banks that failed during 1947 amounted to a little more than 2 per cent of the paid-up capital of the reporting banks. $\frac{15}{}$ The average capital of the failed banks between 1947 and 1955 was significantly lower than the average size of paid-up capital of reporting banks in the industry, suggesting that normally it was small banks that failed (Table 3.12).

\begin{tabular}{|c|c|c|c|c|}
\hline \multirow[b]{2}{*}{$\begin{array}{l}\text { Year } \\
\text { (January- } \\
\text { December) }\end{array}$} & \multirow[b]{2}{*}{$\begin{array}{l}\text { No. of } \\
\text { Falled } \\
\text { Banks }\end{array}$} & \multirow[b]{2}{*}{$\begin{array}{l}\text { Paid-up } \\
\text { Capltal of } \\
\text { Faled } \\
\text { Eanks }\end{array}$} & \multicolumn{2}{|c|}{ (Amount in Rs. lakh } \\
\hline & & & $\begin{array}{l}\text { Average } \\
\text { Pald-up } \\
\text { Capltal of } \\
\text { the Falled } \\
\text { Banks }\end{array}$ & $\begin{array}{r}\text { Average } \\
\text { Pald-up } \\
\text { Capital of the } \\
\text { Reportng } \\
\text { Bank5 }\end{array}$ \\
\hline 1 & 2 & 3 & 4 & 5 \\
\hline 1947 & 38 & 83 & 2 & 105 \\
\hline 1948 & 45 & 183 & 4 & 90 \\
\hline 1949 & 55 & 131 & 2 & 84 \\
\hline 1950 & 45 & 129 & 3 & 102 \\
\hline 1951 & 60 & 62 & 1 & 73 \\
\hline 1952 & 31 & 16 & 1 & 139 \\
\hline 1953 & 31 & 114 & 4 & 135 \\
\hline 1954 & 27 & 48 & 2 & 154 \\
\hline 1955 & 29 & 47 & 2 & 142 \\
\hline
\end{tabular}

1.33 The year 1948 was one of the worst years for the relatively larger banks as 45 institutions (out of more than 637 banks) with paid-up capital averaging about Rs.4 lakh were closed down. They failed as they had overreached themselves by opening more branches than they could sustain on the strength of their resources and by making large loans against property or inadequate security. Some of these, however, had prudential issues as they were functioning with very low capital base. Repeated bank failures caused great hardships to the savers. Failures also reduced faith in the banking system. Most of the savings during this period were in the for $\mathrm{m}$ of land and gold. Household savings constituted 66 per cent of the total domestic savings. Of the total household savings, 89 per cent were in physical assets. $\frac{16}{}$ Financial savings flowed in greater measure to the postal department that was considered a safer avenue due to government ownership. Bank deposits mobilised by commercial banks were largely lent out to security based borrowers in trade and industry.

1.34 The first task before the Reserve Bank after independence, thus, was to develop a sound structure along contemporary lines. It was recognised that banks and banking soundness were crucial in promoting economic prosperity and stability. Banks, through their spread and mobilisation of deposits, promote the banking habits 
and savings in the economy. This could help in garnering resources for investment and development. The initiation of planned economic development required the banking industry to spread far and wide to augment deposit mobilisation and provide banking services.

1.35 The issue of bank failure in some measure was addressed by the Banking Companies Act, 1949 (later renamed as the Banking Regulation Act), but to a limited extent. The Banking Companies Act of 1949 conferred on the Reserve Bank the extensive powers for banking supervision as the central banking authority of the country. $\frac{17}{}$ It focused on basic prudential features for protecting the interests of depositors and covered various aspects such as organisation, management, audit and liquidation of the banking companies. It granted the Reserve Bank control over opening of new banks and branch offices, powers to inspect books of accounts of the banking companies and preventing voluntary winding up of licensed banking companies. The Act was the first regulatory step by the Government of independent India, enacted with a view to streamlining the functioning and activities of commercial banks in India. The Act was long overdue as the Indian Central Banking Enquiry Committee had, in 1931, recommended the enactment of such an Act for India. The most effective of the supervisory powers conferred on the Reserve Bank was the power to inspect banking companies at any time. The Reserve Bank was empowered to inspect any banking company with the objective of satisfying itself regarding the eligibility for a licence, opening of branches, amalgamation, compliance with the directives issued by the Reserve Bank. A key feature contained in this Act was to describe 'banking' as distinct from other commercial operations. This was in line with the traditional role of commercial banks, where banks were considered as a special entity in the financial system, requiring greater attention and separate treatment (Selgin, 1996).

1.36 The Banking Companies Act, however, had some limitations. It did not have adequate provisions against abuse of the powers by persons, who controlled the commercial banks' managements. The Reserve Bank in July 1949 decided to organise efficient machinery for the systematic and periodical inspection of all banking companies in the country, irrespective of their size and standing. The ultimate aim was to create an organisation for the annual inspection of every bank. It was made clear that the primary objective of the inspections was to assist the banks in the establishment of sound banking traditions by drawing their attention to defects or unsatisfactory features in their working methods before they assumed serious proportions necessitating drastic action. The task of evolving an efficient machinery and organisation for conducting the inspections of all the banks was a formidable one.

1.37 Bank failures continued in the period after independence and after the enactment of the Banking Companies Act, although such failures reduced considerably. In order to protect public savings, it was felt that it would be better to wind up insolvent banks or amalgamate them with stronger banks. Accordingly, in the 1950s, efforts were tuned towards putting in place an enabling legislation for consolidation, compulsory amalgamation and liquidation of banks. This was required as the then existing procedure for liquidation was long and time consuming. It involved proceedings in the High Court and caused significant cost and hardship to the depositors. Similarly, the suspension of business was also a long drawn process for licensed banking companies as it involved declaration of moratorium, appointment of official liquidator by the High Court and inspection of the books and accounts of the respective banking companies by the Reserve Bank. Voluntary winding up was an easy exit route for banking companies that were not granted a licence under Section 22, as the provisions of Section 44 did not apply to such banking companies and the prior permission of the Reserve Bank was not required before voluntary liquidation of such companies. This made it easy for the fly-by-night operators to voluntarily wind-up their operations. Many non-scheduled banks, especially in West Bengal became untraceable. Of the 165 non-scheduled banks reported to exist in June 1954, the whereabouts of 107 banks were not known. ${ }^{18}$ The licence of all of these and the remaining non-scheduled banks, barring six, was cancelled.

1.38 Between 1954 and 1966, several banks were either amalgamated or they otherwise ceased to function or their liabilities and assets transferred to other banks. During the six year period before the Reserve Bank was formally given the powers in 1960 to amalgamate banks, a total number of 83 banks were amalgamated. However, between the period from 1960 to 1966, as many as 217 banks were amalgamated under different provisions such as under Section 45 of the BR Act 1949 (compulsory amalgamation) and Section 44 A of BR Act 1949 (voluntary amalgamation). Liabilities and assets of those banks which otherwise ceased to function were transferred to other banks. In the year 1960 alone, as many as 30 banks were amalgamated. However, as a conscious policy, the smaller but well-functioning banks were not consolidated. The transferring the assets and liabilities to other banks proved to be a popular exit route. In 1964 alone, as many as 63 banks went out of business (Table 3.13). The process of bank consolidation was accompanied by a vigorous bank licensing policy, wherein the Reserve Bank tried to amalgamate the unviable units. A number of banks that did not comply with the requisite norms were also delicensed. 
Table 3.13: Commercial Banks Amalgamated - 1954-66

\begin{tabular}{|c|c|c|c|c|c|c|c|c|c|}
\hline \multirow[t]{2}{*}{$\begin{array}{l}\text { Year } \\
\text { (January- } \\
\text { December) }\end{array}$} & \multicolumn{3}{|c|}{$\begin{array}{l}\text { Banks Compulsory } \\
\text { Amalgamated under section } \\
45 \text { of BR Act } 1949\end{array}$} & \multicolumn{3}{|c|}{$\begin{array}{l}\text { Banks Voluntarly } \\
\text { Amalgamated under section } \\
\text { 44 A of BR Act } 1949\end{array}$} & \multicolumn{3}{|c|}{$\begin{array}{l}\text { Banks otherwise Ceased to Function } \\
\text { Transferred their Llabiltles and Assets } \\
\text { to other banks }\end{array}$} \\
\hline & $\begin{array}{l}\text { Na. of } \\
\text { Banks }\end{array}$ & $\begin{array}{l}\text { Pald-up } \\
\text { capital }\end{array}$ & Deposts & $\begin{array}{l}\text { No. of } \\
\text { Banks }\end{array}$ & $\begin{array}{l}\text { Pald-up } \\
\text { capital }\end{array}$ & Depos:s & $\begin{array}{l}\text { No. of } \\
\text { Banks }\end{array}$ & $\begin{array}{l}\text { Pald-up } \\
\text { capital }\end{array}$ & Deposits \\
\hline 1 & 2 & 3 & 4 & 5 & 6 & 7 & 8 & 9 & 10 \\
\hline 1954 & - & - & - & - & - & - & 17 & 25 & 88 \\
\hline 1955 & - & - & - & - & - & - & 11 & 23 & 20 \\
\hline 1956 & - & - & - & - & - & - & 6 & 11 & 47 \\
\hline 1957 & - & - & - & 1 & 5 & 115 & 10 & 19 & 23 \\
\hline 1958 & - & - & - & 4 & 56 & 523 & 10 & 15 & 63 \\
\hline 1959 & - & - & - & 4 & 4 & 33 & 20 & 26 & 110 \\
\hline 1960 & - & - & - & 2 & 1 & 3 & 15 & 34 & 40 \\
\hline 1961 & 30 & 196 & 1722 & - & - & - & 9 & 17 & 142 \\
\hline 1962 & 1 & 1 & 6 & 3 & 20 & 122 & 22 & 55 & 136 \\
\hline 1963 & 1 & 1 & 7 & 2 & 3 & 16 & 15 & 34 & 781 \\
\hline 1964 & 9 & 36 & 438 & 7 & 23 & 147 & 63 & 55 & 569 \\
\hline 1965 & 4 & 13 & 54 & 5 & 3 & 39 & 24 & 59 & 501 \\
\hline 1966 & - & - & - & - & - & - & 7 & 19 & 453 \\
\hline
\end{tabular}

1.39 The process of strengthening of the banking sector also took the form of weeding out the unviablebanks by liquidation or the taking of the assets of the non-functioning banks by other banks. During the period 1954 to 1959 as many as 106 banks were liquidated. Of these, 73 banks went into voluntary liquidation and 33 went into compulsory liquidation. Between 1960 to 1966, another 48 banks went into liquidation (Table

Table 3.14: Commercial Banks under Liquidation - 1954-66

\begin{tabular}{|c|c|c|c|c|c|c|}
\hline & & & & & & in R5. ${ }^{\circ}(0)$ ) \\
\hline \multirow{2}{*}{$\begin{array}{l}\text { Year } \\
\text { (January- } \\
\text { December) }\end{array}$} & \multicolumn{3}{|c|}{ Banks which went into voluntary Liquidation } & \multicolumn{3}{|c|}{ Banks which went into Compusory Liquidation } \\
\hline & No. of Banks & Paid-up capital & Deposits & No of Banks & Palch-up captal & Depos:5 \\
\hline 1 & 2 & 3 & 4 & 5 & 6 & 7 \\
\hline 1954 & 14 & 1374 & 96 & 6 & 2846 & 1140 \\
\hline 1955 & 11 & 2655 & 199 & 6 & 2510 & 10102 \\
\hline 1956 & 16 & 1452 & 499 & 6 & 695 & 1812 \\
\hline 1957 & 16 & 1682 & 1659 & 3 & 917 & 2876 \\
\hline 1958 & 9 & 927 & 1135 & 5 & 1367 & 10209 \\
\hline 1959 & 7 & 566 & 6 & 7 & 2722 & 506 \\
\hline 1960 & 4 & 238 & 34 & 5 & 5375 & 107027 \\
\hline 1961 & 5 & 403 & 814 & 3 & 1106 & 3332 \\
\hline 1962 & 4 & 786 & 12 & 3 & 969 & 5145 \\
\hline 1963 & 1 & 90 & 11 & 1 & 224 & 1108 \\
\hline 1964 & 3 & 225 & - & - & - & - \\
\hline 1965 & 6 & 703 & - & 3 & 1359 & 137 \\
\hline 1965 & 7 & 703 & - & 3 & 225 & 21 \\
\hline
\end{tabular}

1.40 The policy of strengthening of the banking sector through a policy of compulsory amalgamation and mergers helped in consolidating the banking sector. The success of this could be gauged from the visible reduction in the number of non-scheduled banks from 474 in 1951 to 210 in 1961 and further to 20 in 1967. Their branch offices declined from 1504 in 1951 to 622 in 1961 and to 203 in 1967 (Table 3.15).

Table 3.15: Scheduled and Non-Scheduled Commercial Banks in India

\begin{tabular}{|c|c|c|c|}
\hline \multirow[b]{2}{*}{ Category of banks } & \multicolumn{3}{|c|}{ (End-December) } \\
\hline & 1961 & 1966 & 1967 \\
\hline 1 & 2 & 3 & 4 \\
\hline \multirow{3}{*}{$\begin{array}{l}\text { 1. Number of Banks (Reporting) } \\
\text { (a) Scheduled Banks } \\
\text { (d) Non-5cheduled Eanks }\end{array}$} & 292 & 100 & 91 \\
\hline & 82 & 73 & 71 \\
\hline & 210 & 27 & 20 \\
\hline \multirow{3}{*}{$\begin{array}{l}\text { 2. Number of Omces of Banks in indla } \\
\text { (a) Scheduled Banks } \\
\text { (d) Non-5cheduled Banks }\end{array}$} & 5012 & 6593 & 6982 \\
\hline & 4390 & 6360 & 6779 \\
\hline & 622 & 213 & 203 \\
\hline
\end{tabular}

1.41 The bank failures and the hardship caused to the depositors led the Reserve Bank to provide safety nets to 
depositors. The Banking Companies (Second Amendment) Act, 1960, which came into force in September 19, 1960 sought to facilitate expeditious payments to the depositors of banks in liquidation and also vested the Government and the Reserve Bank with additional powers to rehabilitate banks in difficulties. Prior to the Amendment, the procedure for determination of claims of secured creditors and other persons entitled to preferential treatment was mainly responsible for a good deal of delay in the payment to depositors of banks in liquidation. The new provision required that such preferential payment should be made or provided for within three months from the date of the winding-up order or within three months from the date of commencement of the Amendment Act in respect of banks which had gone into liquidation earlier. It further provided that after the preferential payments, the three-month period as specified in the Act, every saving bank depositor should be paid the balance at his credit, subject to a maximum of Rs. 250 .

1.42 In order to ensure the safety of deposits of small depositors in banks in India, the Deposit Insurance Corporation Act, 1961 was enacted. Accordingly, Deposit Insurance Corporation of India was established in January 1962. India was then one of the few countries to introduce such a deposit insurance; the US was the first country to introduce the deposit insurance. This scheme was expected to increase depositors' confidence in the banking system and was expected to facilitate the mobilisation of deposits and help promote the spread and growth of the banking sector. The Corporation provided insurance cover against loss of all or part of deposits with an insured bank up to a certain level.As a regulator of the banking system; the Reserve Bank was empowered by the Banking Companies Act to inspect banks. The instances of failures of banks in Kerala that occurred due to misappropriation of depositors' funds by directors underscored the need to strengthen the mechanism of inspection. Accordingly, changes in the policy regarding inspection were made to undertake surprise inspection of banks, and cover many more branches than in the past to detect frauds. The legislative changes that followed took shape in the insertion of a new Chapter IIIA in the RBI Act in 1962. The entire purpose of regulation of banking was to plug the loopholes in law that permitted any irregularity. An amendment Act passed in 1963, which became effective February 1, 1964, gave further powers to the Reserve Bank, particularly to restrain the control exercised by particular groups of persons over the affairs of banks and to restrict loans and advances as well as guarantees given by banks. It also enlarged the Reserve Bank's powers of control in the appointment and removal of banks' executive personnel.

\section{Lending to Agriculture and Spread of Banking to Rural Areas}

1.43 With independence, not only did the operating environment change but policies also were geared towards planned objectives. Regulation was also aligned to the attainment of these objectives. The adoption of the Constitution in 1950 and the enactment of the State Reorganisation Act in 1956 brought banking in the entire country under the purview of the Reserve Bank. These also enhanced the ambit of the Reserve Bank as a banker to the Government. The Reserve Bank was expected to fill the resource gap for planned purposes. The First Five Year Plan observed that central banking in a planned economy could hardly be confined to the regulation of the overall supply of credit or to a somewhat negative regulation of the flow of bank credit. It would have to take on a direct and active role (i) in creating or helping to create the machinery needed for financing developmental activities all over the country; and (ii) ensuring that the finance available flows in the directions intended.

1.44 The Government's desire to use banking as an important agent of change was at the heart of most policies that were formulated after independence. These were the first attempts at enhancing the outreach of institutional credit. In India, thus, there was very little support for 'passive' or 'pure' role of banking. Banks were considered unique among financial institutions and were assigned a developmental role from the beginning of the planned era. Resources amassed from deposit mobilisation were required to be channeled to the most productive uses and the banking system was expected to function as an efficient conduit of the payment system. In doing this, the banking sector was expected to spread the institutional credit across the country. The need for these changes stemmed from the fact that at the time of independence of the country, the banking sector in India was relatively small, weak and concentrated in the urban areas. Most banks in the organised sector engaged primarily in extending loans to traders dealing with agricultural produce.

1.45 Banking had not penetrated into the rural and semi-urban centres and usury was still having a field day. A great degree of inter-linkage of markets of agricultural output and credit existed with the agricultural moneylender and traders giving advances to the cultivator and purchasing his produce at less than the market price. Such an inter-linkage between the credit and the output markets had sustained high interest rates and low product price cycles that brought about a high-interest rate-high debt-low income kind of equilibrium. This was sustained as institutional bank credit was not available to agriculture, small industries, professionals and selfemployed entrepreneurs, artisans and small traders. Researchers found that since the rural credit markets were isolated, the moneylenders/landlords could act as monopolists and charge exorbitantly high rates of interest to cultivators (Bhaduri, 1977). The inter-linkage of markets of output, credit and labour could be effectively broken only by the spread of the institutional credit. Co-operatives had penetrated into the rural sector but were weak. At the time of independence, most of the bank credit went to commerce and industry, and very little to 
agriculture (Table 3.16). This was despite the fact that agriculture constituted about 55 per cent of GDP in 1950.

\begin{tabular}{|c|c|c|c|c|c|c|}
\hline \multirow[b]{2}{*}{ As at End } & \multirow[b]{2}{*}{ Total (Rs. crore) } & \multicolumn{5}{|c|}{ Share in Total (per cent) } \\
\hline & & Inoustry & Commerce & Agriculture & $\begin{array}{l}\text { Personal and } \\
\text { Protessional }\end{array}$ & Others \\
\hline 1 & 2 & 3 & 4 & 5 & 6 & 7 \\
\hline Decenter, 1949 & 439 & 30.4 & 51.4 & 1.9 & 8.7 & 7.6 \\
\hline March 1950 & 498 & 31.5 & 52.1 & 2.3 & 7.9 & 6.3 \\
\hline June, 1950 & 476 & 32.5 & 50.1 & 3.2 & 8.2 & 6.0 \\
\hline September, 1960 & 438 & 340 & 47.6 & 3.3 & 9.4 & 5.6 \\
\hline December, 1950 & 476 & 32.0 & 51.7 & 23 & 8.9 & 5.1 \\
\hline
\end{tabular}

1.46 Lack of knowledge of the area caused asymmetry of information and the grant of small agricultural loans required the banks to maintain a large number of small accounts that were both time-consuming and less profitable. Besides, lending operations were largely security based and the small borrowers had very little security apart from their land, which was often not unencumbered. According to the All India Rural Credit Survey Committee, the total borrowing of the farmers was estimated at Rs.750 crore in 1951-52. Of this, commercial banks provided only 0.9 per cent, agriculturist moneylenders provided 24.9 per cent and professional money lenders another 44.8 per cent. Thus, the financial system at the time of independence was typically underdeveloped. In 1951, there were 551 commercial banks in the country. The bank office to population ratio was at a staggering one branch per $1,36,000$ persons. ${ }^{20}$ Saving habits had also not developed adequately, with the saving rate being at 10 per cent of national income. The underdeveloped banking system was characteristic of a more general lack of depth in the financial system. The needs of the agricultural sector were not met adequately as the banks had no expertise or desire to expand their rural operations. Moreover, banks were run by business houses with other considerations such as profit and financing parent industries. The agricultural operation did not interest many of them.

1.47 Extending the banking facilities to the rural areas was a prominent objective at the time of independence. It was suggested that the Imperial Bank of India should extend its branches to taluka or tehsil towns where the volume of government transactions and business potentialities warranted such extension. ${ }^{21}$ The Imperial Bank of India was given a target of opening 114 offices within a period of 5 years commencing from July 1, 1951. Other commercial banks and co-operative banks were advised to endeavour to extend their branches to the taluka towns, smaller towns and semi-urban areas. For the villages, it was considered desirable that the machinery of the postal savings banks and cooperative banks should be expanded and more fully utilised. As against the intention to open 114 branches in 5 years, the Imperial Bank of India could open only 63 branches till June 20, 1955 .

1.48 The Reserve Bank assumed a unique role in this context that was occasioned by the predominantly agricultural base of the Indian economy and the urgent need to expand and co-ordinate the institutional credit structure for agriculture and rural development. The policy initiative by the Reserve Bank/Government was three-fold. First, to understand the dimension of the problem, a committee was set up. Second, the Imperial Bank of India was nationalised. Third, to address the issue of training of the bank officials in the area of agricultural banking, an institution was set up.

1.49 In order to understand the grass root level situation to be able to address the concerns regarding the financing of the rural sector, the Reserve Bank commissioned the All India Rural Credit Survey Committee (AIRCS) in 1951. The AIRCS survey results were submitted in August 1954 and published in December the same year. The survey had very clear suggestions regarding the Reserve Bank's development role. The agenda for action and institution-building proposed by the All-India Rural Credit Survey Committee was, by almost any reckoning, impressive in scope and ambition..$^{22}$ Equally more impressive were its principal recommendations.

1.50 The State Bank of India, which was required to open 400 branches within 5 years in unbanked centres, exceeded the target by opening 416 branches (Mathur, 1995). The SBI was envisaged to act as the principal agent of the Reserve Bank to handle banking transactions of the Union and the State Governments throughout the country. The step was, in fact, in furtherance of the objectives of supporting a powerful rural credit cooperative movement in India. Its establishment led to a great deal of change in the banking scenario. With the setting up of the State Bank of India, a large number of branches were opened in unbanked centres. The 'Government' ownership of the State Bank of India helped it to compete with 'safe' avenues like post offices and physical savings. The sustained efforts to expand branch network had a positive impact on deposit mobilisation by banks and the overall savings rate. Aggregate deposits of scheduled commercial banks, which registered a negative growth in 1951-1953 and a small positive growth of 1.9 per cent in 1953-54, grew by 1012 per cent during the period 1954-55 and 1956-57 (Table 3.17). The increased deposit mobilisation was also 
facilitated by the increased income levels. The Five Year Plan had a high multiplier effect on the economy. The income levels rose rapidly, which led to the spread of banking habits.

\section{Table 3.17: Scheduled Commercial Banks - Deposit Mobilisation}

\begin{tabular}{|c|c|c|c|c|c|c|}
\hline \multirow[b]{2}{*}{$\begin{array}{l}\text { Year } \\
\text { (April -March) }\end{array}$} & \multirow[b]{2}{*}{$\begin{array}{l}\text { Demand } \\
\text { Depos:t5 }\end{array}$} & \multirow[b]{2}{*}{$\begin{array}{l}\text { Growa Riate } \\
\text { of Demand } \\
\text { Deposits } \\
\text { (per cent) }\end{array}$} & \multirow[b]{2}{*}{$\begin{array}{r}\text { Time } \\
\text { Deposits }\end{array}$} & \multirow[b]{2}{*}{$\begin{array}{l}\text { Growth Rate of } \\
\text { Time Deposits } \\
\text { (per cent) }\end{array}$} & \multicolumn{2}{|c|}{ (Amount in Fupees crore) } \\
\hline & & & & & $\begin{array}{r}\text { Aggregate } \\
\text { Deposits } \\
(2+4)\end{array}$ & $\begin{array}{r}\text { Growth Fate of } \\
\text { Aggregate } \\
\text { Deposits } \\
\text { (per cent) }\end{array}$ \\
\hline 1 & 2 & 3 & 4 & 5 & 6 & 7 \\
\hline $1951-52$ & 566 & -4.4 & 286 & -1.4 & 852 & -34 \\
\hline $1952-53$ & 522 & -7.8 & 310 & 8.4 & 832 & -2.3 \\
\hline $1953-54$ & 522 & 0.0 & 326 & 5.2 & $8 \angle B$ & 1.9 \\
\hline $1954-55$ & 568 & 8.6 & 375 & 150 & 943 & 11.2 \\
\hline $1955-56$ & 631 & 11.1 & 412 & 9.9 & 1043 & 10.6 \\
\hline $1956-57$ & 703 & 11.5 & 472 & 14.6 & 1176 & 12.7 \\
\hline
\end{tabular}

1.51 The increased deposit mobilisation by banks had a favourable impact on financial savings, which grew sharply during 1954-55 to 1955-56. A part of the increased financial savings during 1953-54 and 1955-56 emanated from conversion of physical savings into financial savings (Table 3.18).

Table 3.18: Household Sector Savings

\begin{tabular}{|c|c|c|c|c|c|c|c|c|c|}
\hline \multirow[b]{2}{*}{$\begin{array}{l}\text { Year } \\
\text { (April- } \\
\text { March) }\end{array}$} & \multirow[b]{2}{*}{$\begin{array}{r}\text { Household } \\
\text { sector } \\
\text { Financial } \\
\text { Seaings }\end{array}$} & \multirow[b]{2}{*}{$\begin{array}{r}\text { Growth in } \\
\text { Housahold } \\
\text { sector } \\
\text { Financial } \\
\text { Savings } \\
\text { (per cant) }\end{array}$} & \multirow[b]{2}{*}{$\begin{array}{r}\text { Household } \\
\text { sector } \\
\text { Prysical } \\
\text { Savings }\end{array}$} & \multirow[b]{2}{*}{$\begin{array}{l}\text { Growth } n \\
\text { Househcld } \\
\text { seckr } \\
\text { Prysical } \\
\text { Savings } \\
\text { (per cent) }\end{array}$} & \multirow[b]{2}{*}{$\begin{array}{r}\text { Total } \\
\text { Housenctd } \\
\text { Sevings } \\
(2+4)\end{array}$} & \multirow[b]{2}{*}{$\begin{array}{r}\text { Growth in } \\
\text { Total } \\
\text { Household } \\
\text { Savings } \\
\text { (per cent) }\end{array}$} & \multirow[b]{2}{*}{$\begin{array}{r}\text { Groes } \\
\text { Domeellic } \\
\text { Servings }\end{array}$} & \multicolumn{2}{|c|}{ (Amcunt n Rupees crore) } \\
\hline & & & & & & & & $\begin{array}{l}\text { Growith in } \\
\text { Groes } \\
\text { Domeetlic } \\
\text { Seaings } \\
\text { (per cant) }\end{array}$ & $\begin{array}{r}\text { Total } \\
\text { Houkehold } \\
\text { Savings b } \\
\text { GDP } \\
\text { (per cant) }\end{array}$ \\
\hline 1 & 2 & 3 & 4 & 5 & 6 & 7 & 8 & 9 & 10 \\
\hline 1951.52 & 14 & -774 & 582 & 31 & 546 & -5.5 & 969 & 11,3 & 5.3 \\
\hline $1952-53$ & 72 & 414.3 & 527 & -0.9 & 599 & 9.7 & 845 & -128 & 5.9 \\
\hline $1953-54$ & 142 & 97.2 & 474 & -10.1 & 616 & 2.8 & 875 & 3.6 & 5.6 \\
\hline $1954-55$ & 282 & 98.6 & 399 & -17.9 & 671 & 8.9 & 988 & 12.8 & 6.5 \\
\hline $1955 \cdot 56$ & 429 & 521 & 562 & 44.5 & 921 & 47.7 & 1356 & 37.3 & 8.4 \\
\hline
\end{tabular}

1.52 Eight banks that then formed subsidiaries of SBI were nationalised in 1960. This brought one-third of the banking segment under the direct control of the Government. The idea was to spread institutional credit far and wide in order to free the average Indian from the often exorbitant interest rate-debt cycle. Another recommendation of the Committee related to the restructuring of the short-term cooperative credit structure and the reorganisation of the institutions specialising in longer-term lending for agricultural development. The Report drew attention towards the need to have adequate institutional credit for medium-term lending to agriculture. These efforts culminated in the creation of Agricultural Refinance Corporation of India in 1963, which was to provide funds by way of refinance. To finance such investments, the Agricultural Refinance Corporation (ARC) was set up by the Act of July 1, 1963. Its objective was to refinance central land mortgage banks, State cooperative banks and scheduled commercial banks.

1.53 In order to address the genuine shortage of trained and experienced professional managers in the banking sector, the Reserve Bank took over the task of providing training facilities for the personnel involved in agrirural development, co-operative banking and related areas to tone up effectiveness of their managerial staff. Accordingly, the Bankers' Training College was set up by the Reserve Bank in 1954 for "the purpose of imparting training to bank personnel and improving the quality of management of banks in India".

1.54 The Banking Companies Act (section 23) required the banks to obtain the permission of the Reserve Bank before opening a new place of business. The mandate of spreading the umbrella of institutional credit was addressed by putting in place a 'New Branch Licensing Policy' in May 1962. The bank expansion policy put in place some entry level norms to take care of prudential requirements like in many other countries that had put in place extensive legal and regulatory norms for entry of banks. The rationale was to reinforce the bank's internal governance structure and to ensure market discipline. This policy also addressed the social goal of spread of banking as it laid the stress on starting banks in unbanked areas. The identification of unbanked areas was undertaken by examining the data on population per bank office. The new licensing policy marked a change in focus for extension of the banking facilities throughout the country. Prior to the initiation of new policy, branch licenses were granted primarily on the basis of the financial position of banks. It was felt that by linking the grant of permission to open new offices with the financial position of the applicant bank, the general quality of its management, the adequacy of its capital structure and its future earnings prospects could be addressed. With the issue of viability of the banks, the expansion of smaller banks would be discouraged. That is, the policy 
discriminated in favour of larger and all-India banks.

1.55 In every single year between 1913 and 1955, several banks failed in India (Annex III.1). The number of reporting banks increased till 1945, but declined steadily thereafter (Annex III.2).

1.56 The number of branches increased significantly between 1952 and 1960 and further between 1960 and 1967. The population per office declined from 1,36,000 in 1951 to 92,000 in 1960 and further to 65,000 in 1967. However, the pattern of branches in rural/semi-urban and urban/metropolitan centres remained broadly unchanged (Table 3.19). The share of agriculture in credit dispensed by scheduled commercial banks also did not improve. Credit to agriculture constituted only 2.2 per cent, i.e., an increase of merely 0.1 per cent between 1951 and 1967 in sharp contrast to almost doubling of the share of industry from 34 per cent in 1951 to 64.3 per cent in 1967 (Table 3.20).

\begin{tabular}{|c|c|c|c|c|}
\hline End-Decemb & Rura & $\begin{array}{l}\text { Semi } \\
\text { Urben }\end{array}$ & $\begin{array}{l}\text { Urben } \\
\text { Metropoltar }\end{array}$ & Total \\
\hline 1 & 2 & 3 & & 5 \\
\hline 1952 & $\begin{array}{r}540 \\
(13.3)\end{array}$ & $\begin{array}{r}1942 \\
(47.8)\end{array}$ & $\begin{array}{r}1451 \\
(85.7\end{array}$ & $4061 \neq$ \\
\hline 1960 & $\begin{array}{r}831 \\
(16.5)\end{array}$ & $\begin{array}{l}2512 \\
(50.0)\end{array}$ & $\begin{array}{r}1639 \\
(33.5)\end{array}$ & 5026 \\
\hline 1965 & $\begin{array}{r}801 \\
(13.1)\end{array}$ & $\begin{array}{r}2836 \\
(48.2)\end{array}$ & $\begin{array}{r}235 . \\
(39.4)\end{array}$ & $6138^{*}$ \\
\hline 1967 & $\begin{array}{r}1247 \\
(17.9)\end{array}$ & $\begin{array}{r}3022 \\
(43.3)\end{array}$ & $\begin{array}{r}2716 \\
(38.9)\end{array}$ & 6985 \\
\hline \multicolumn{5}{|c|}{$\begin{array}{l}\text { \# : } 128 \text { branchas were unctassiliad } \\
\text { : } 142 \text { branchas were unctassiliad } \\
\text { Note : Flgures in perentheses are percentage to total. } \\
\text { Source : Statletical Abetract Relating b Banks in indla, varlous } \\
\text { lasurs. }\end{array}$} \\
\hline \multicolumn{5}{|c|}{$\begin{array}{l}\text { Table 3.20: Advances of Scheduled Commercial } \\
\text { Banks to Various Sectors } \\
\text { (Amount in Pupees core) }\end{array}$} \\
\hline \multirow[b]{2}{*}{ Sector } & \multicolumn{2}{|c|}{ End-March 1951} & \multicolumn{2}{|c|}{ End-March 1967} \\
\hline & Amourt : & $\begin{array}{l}\text { Share in Total } \\
\text { Advancas } \\
\text { (per cent) }\end{array}$ & Amount & $\begin{array}{r}\text { Share in Total } \\
\text { Advances } \\
\text { (per cent) }\end{array}$ \\
\hline 1 & 2 & 3 & 4 & 5 \\
\hline Industry & 199 & 34.0 & 1747 & 64.3 \\
\hline Commerce & 211 & 36.0 & 527 & 19.4 \\
\hline Fingnclal & 74 & 12.7 & 97 & 3.6 \\
\hline Personsi & 40 & 6.8 & 115 & 42 \\
\hline Agriculture & 12 & 2.1 & 57 & 22 \\
\hline Chers & 49 & 8.4 & 174 & 6.3 \\
\hline Total & 585 & 100 & 2716 & 100 \\
\hline
\end{tabular}

\section{Emergence of Administered Structure of Interest Rates and Micro Controls}

1.57 This period was also difficult for monetary policy as it had to accommodate fiscal policy that was under pressure on account of two wars and a drought. The rising deficit and the accompanying inflation led to an administered structure of interest rates and several other micro controls. In early years, the Reserve Bank relied on direct control over the lending rates of banks, rather than indirect instruments such as the Bank Rate for influencing the cost of bank credit. This was generally done by stipulating minimum rates of interest. The exigencies also required further sub-classification of interest rates with minimum lending rates being separately prescribed for credit against various commodities covered under selective credit control. Also, concessional or ceiling rates of interest were made applicable to advances for certain purposes or to certain sectors to reduce the interest burden, thereby facilitating their development. Interest rates on deposits were also regulated in September 1964. The objectives behind fixing the rates on deposits were to avoid unhealthy competition amongst the banks for deposits and keep the level of deposit rates in alignment with the lending rates of banks to ensure the profitability of banks. Prior to these, changes in interest rates were governed by voluntary inter-bank agreements amongst the important Indian and foreign banks which used to fix ceilings on interest rates. Thus, interest rate regulations were aimed at satisfying the conflicting objectives such as enhancing savings rate, while keeping the cost of credit for productive activities at a reasonably low level. These seemingly opposing objectives were addressed by setting the interest rates according to depositor, borrower, purpose, the background of the borrower, his economic status, type of activity for which the credit was granted and the amount of such credit. Some change in the pattern of deposits was also sought to be achieved by change in the interest rate across the deposit categories. To encourage long-term deposits, the ceilings on deposit rates as well as 
specification of floors for longer term deposits were prescribed. The need for resources for planned development gradually increased the Government borrowing. The overriding objective of keeping the cost of Government borrowing low, in addition to objectives of promoting growth, and the difficulty in reducing interest rates on bank deposits once they were raised, brought in considerable inflexibility in interest rate determination. While in some measure, all the avowed objectives were addressed, the interest rates ceased to function as a signal of monetary policy. The banks usually compete with each other by setting competitive interest rates. However, under the administrative set-up, the spreads of the banks were well worked out and the banks lost all initiative to optimise their resources, offer competitive rates and retain business. The net result was that borrowers had to pay higher interest rates. Because of the administered structure of interest rates, banks also could not price their products depending on the creditworthiness of the borrowers which also led to misallocation of resources.

1.58 The period during 1961 to 1967 was particularly difficult for the nation. These years witnessed two wars and a series of poor harvest seasons. Given the unstable situation and increased requirement of the public expenditure to be financed against the backdrop of a stagnating agriculture, the Government left no effort spared to ensure that the resources of the banking sector did not go into speculative or unproductive channels. Inflation was high and at times shortages also developed.In 1966, the banking sector was increasingly subjected to selective credit controls. The issue of concentration of resources in the hands of a few entities starved the genuinely productive sectors. It was, therefore, decided to take measures to promote effective use of credit and prevent the larger borrowers from pre-empting scarce credit and enlarging the spectrum of borrowers covered by bank credit in the overall context of national priorities as enunciated over the years. Under the Credit Authorisation Scheme(CAS) introduced in 1965, the commercial banks were required to obtain prior permission of the Reserve Bank for sanctioning any fresh working capital limits above the prescribed norm which was revised from time to time. It was first set at Rs. one crore or more to any single party or any limit that would take the total limits enjoyed by such a party from the entire banking system to Rs. one crore or more, on a secured and/or unsecured basis. While in the first few years, the CAS meant no more than a scrutiny of proposed credit facilities with a view to ensuring that large borrowers were not unduly favoured by banks, in the subsequent years, it was seen as a means to achieving a closer alignment between the requirements of the Five Year Plans and the banks' lending activities.

1.59 To sum up, the banking scenario that prevailed in the early independence phase had three distinct disquieting features. One, bank failures had raised the concerns regarding the soundness and stability of the banking system. Two, there was large concentration of resources from deposits mobilization in a few hands of business families or groups. Banks raised funds and on-lent them largely to their controlling entities. Three, agriculture was neglected insofar as bank credit was concerned. A major development during this period was the enactment of the Banking Regulation Act empowering the Reserve Bank to regulate and supervise the banking sector. These powers become necessary as banks continued to fail even after the Independence, although the number of banks that failed declined. The Reserve Bank was fairly successful in improving the safety and soundness of the banking sector over time as several weak banks (most of which were non-scheduled) were weeded out through amalgamations/liquidations. As a result, the number of non-scheduled banks declined sharply from 475 in 1951 to 20 in 1967 . The banking sector grew steadily due to the impetus from the 'multiplier' effect of large public investments that led to higher incomes and structural changes in the economy during this period.

1.60 The main objectives of social control was to achieve a wider spread of bank credit, prevent its misuse, direct a larger volume of credit flow to priority sectors and make it more effective instrument of economic development. Social control was necessary to evolve proper guidelines for bank managements and to promote a re-orientation of their decision-making machinery in line with the plan priorities. It was felt that a purposeful and equitable distribution of credit should be ensured with the help of periodical assessment of the demand for bank credit, determination of priorities for lending and investment amongst various sectors of the economy and adequate follow-up of these by the banking system. It was expected that such a step would ensure a better alignment of the banking system with the needs of economic policy. The National Credit Council (NCC) was set up in February 1968 to assist the Reserve Bank and the Government to allocate credit according to plan priorities. It was entrusted with the task of (i) estimating the demand for bank credit from the different sectors of the economy; and (ii) fixing priorities for grant of loans or for investment after taking into account the availability of resources, and needs of the priority sectors, especially agriculture, small scale industries and exports. The council worked towards bringing about an optimum utilisation of resources by coordinating the lending and investment policy of commercial and co-operative banks and other specialised institutions. In the broader picture, the commercial banking sector and co-operatives were to supplant the usurious network of the moneylenders and its indigenous variants that charged exorbitant interest rates. In terms of the recommendations of the National Credit Council, the Banking Regulation Act was amended on February 1, 1969 in order to enable the appointments of directors with specialised knowledge or practical experience in the fields of agriculture, small scale industry, co-operation, rural economy as members of the boards of directors of 
commercial banks with the approval of the Reserve Bank. The scheme of social control was aimed at bringing some changes in the management and through it distribution of credit by the commercial banks and delinking the nexus between big business houses and big banks. Despite the system of social control on banks, a large segment of the population remained outside the purview of the organised sector credit.

\section{Nationalisation of Banks and Spread of Banking}

1.61 Although the banking system had made some progress in terms of deposit growth in the 1950s and the 1960s, its spread was mainly concentrated in the urban areas. The progress regarding the social objectives was not adequate. A notable feature of Indian commercial banking was the control of the major banks by leaders of commerce and industry. Banks were run to satisfy their requirements rather than along commercial principles. The consequence was the gradual erosion in the capital base of banks. The ratio of paid-up capital and reserves to deposits declined by more than 75 per cent from 9.7 per cent in 1951 to 2.2 per cent in $1969 .^{27}$ The rapid increase in deposits in relation to their owned capital enabled the industrialist shareholders to enjoy immense leverage. It was felt that if bank funds had to be channeled for rapid economic growth with social justice, there was no alternative to nationalisation of at least the major segment of the banking system. Accordingly, the Government nationalised 14 banks with deposits of over Rs.50 crore by promulgating the Banking Companies (Acquisition and Transfer of Undertakings) Ordinance, 1969. These banks were the Central Bank of India, Bank of Maharashtra, Dena Bank, Punjab National Bank, Syndicate Bank, Canara Bank, Indian Overseas Bank, Indian Bank, Bank of Baroda, Union Bank, Allahabad Bank, United Bank of India, UCO Bank and Bank of India. The objective was to serve better the needs of development of the economy in conformity with national policy objectives.

1.62 It was believed that nationalisation would mark a new phase in the implementation of the nation's avowed objectives and policies. It was also felt that bank deposits could be used for furthering the economic development of the country as a whole rather than for certain industries and business houses. Thus, the immediate tasks set for the nationalised banks were mobilisation of deposits on a large scale and on-lending those funds for all productive activities, irrespective of the size and social status of the borrower, particularly to weaker sections of the society. On the eve of nationalisation, the banks had a definite urban orientation as about 44 per cent of total deposits and 60 per cent of total credit were accounted for by the five centres (Table 3.21).

Table 3.21: Share of Major Cities in Total Deposits and Credit of Banks: End-December 1969

\begin{tabular}{|c|c|c|c|c|c|c|c|}
\hline \multirow[b]{3}{*}{$\begin{array}{l}\text { Sr. } \\
\text { No. }\end{array}$} & \multirow[b]{3}{*}{ chy } & & & & & (Amo & In Rupees crore \\
\hline & & \multirow[b]{2}{*}{$\begin{array}{l}\text { No. of } \\
\text { Ornces }\end{array}$} & \multicolumn{2}{|c|}{ Depos::5 } & \multicolumn{2}{|c|}{ Credit } & \multirow[b]{2}{*}{$\begin{array}{r}\text { Credit-Depost: } \\
\text { Ratio } \\
\text { (per cent) }\end{array}$} \\
\hline & & & Amount & $\begin{array}{r}\text { Percentage } \\
\text { share in } \\
\text { Total }\end{array}$ & Amount & $\begin{array}{r}\text { Percentage } \\
\text { share in } \\
\text { Total }\end{array}$ & \\
\hline & 2 & 3 & 4 & 5 & 6 & 7 & 8 \\
\hline 1. & Anmedabad & 119 & 117 & 22 & 117 & 3.1 & 100.6 \\
\hline 2. & Bombay & 456 & 964 & 18.6 & 976 & 26.2 & 101.3 \\
\hline 3. & Calcutta & 258 & 573 & 11.2 & 694 & 18.6 & 121.1 \\
\hline 4. & Deln! & 296 & 493 & 9.5 & 200 & 5.4 & 40.6 \\
\hline \multirow[t]{3}{*}{5.} & Madras & 178 & 140 & 2.7 & 248 & 6.6 & 175.8 \\
\hline & Total (1 to 5 ) & 1,307 & 2,287 & 44.2 & 2,235 & 59.9 & 97.7 \\
\hline & All indla & 9,007 & 5,173 & 100 & 3,729 & 100 & 72.1 \\
\hline
\end{tabular}

1.63 The Indian banking system underwent major structural transformation after the nationalisation in 1969. To address the issue of urban orientation, specific emphasis was laid on making banking facilities available in the then unbanked areas. This was executed through two definite steps, viz., by designing a specific branch licence policy and by initiating specific schemes like the Lead Bank Scheme (LBS). The LBS, launched by the Reserve Bank with a view to mobilising deposits on a massive scale throughout the country and also for stepping up lending to weaker sections of the economy, became the principal instrument for branch expansion. The 'lead bank' designated for the district was responsible for taking lead role in surveying the credit needs of the population, development of banking and of credit facilities in the district allotted to it.

1.64 Initially, all the districts of the country (barring metropolitan cities and the union territories) were allotted to 22 public sector banks (SBI and its 7 associates banks and 14 nationalised banks) and three private sector banks (Andhra Bank Ltd., Bank of Rajasthan Ltd. and Punjab and Sind Bank Ltd.). While allotting districts to the banks, the resource base of the bank concerned and regional orientation of banks were taken into consideration. Districts were allotted in clusters to facilitate control and in each State two or more than two banks were allotted the responsibility of districts. Each bank was also allotted districts in more than one State. The allotment of districts to various banks under the LBS had a major role in the spread of banking to unbanked centres. In about 5 years after nationalisation of banks, the branch network expanded by 129 per cent. The population per bank office declined from 65,000 per bank office in June 1969 to 31,660 in December 1975. Of the 10,543 new branches opened, 5,364 (50.1 per cent) were in rural areas. As a result, the share of rural 
branches in total bank branches increased from 17.6 per cent in 1969 to 36.3 per cent in 1975 (Table 3.22).

Table 3.22: Branch Network of Commercial Banks

\begin{tabular}{|c|c|c|c|c|c|c|}
\hline As at end & $\begin{array}{l}\text { Rural } \\
\text { Centres }\end{array}$ & $\begin{array}{l}\text { Seml-uroan } \\
\text { Cenitres }\end{array}$ & $\begin{array}{l}\text { Urtann } \\
\text { Centres }\end{array}$ & $\begin{array}{r}\text { Metropolitan } \\
\text { Centresiport } \\
\text { Towns }\end{array}$ & Total & $\begin{array}{l}\text { Population per } \\
\text { Sank ofnce }\end{array}$ \\
\hline 1 & 2 & 3 & 4 & 5 & 6 & 7 \\
\hline June 1969 & $\begin{array}{l}1,4.43 \\
(17.6)\end{array}$ & $\begin{array}{l}3,337 \\
(40.8)\end{array}$ & $\begin{array}{l}1,911 \\
(23.3)\end{array}$ & $\begin{array}{r}1,496 \\
(18.3)\end{array}$ & 8,187 & 65,000 \\
\hline Decentoer 1975 & $\begin{array}{l}6,807 \\
(36.3)\end{array}$ & $\begin{array}{l}5,596 \\
(29.9)\end{array}$ & $\begin{array}{r}3,489 \\
(18.6)\end{array}$ & $\begin{array}{l}2,836 \\
(15.1)\end{array}$ & 18.730 & 31,660 \\
\hline December 1980 & $\begin{array}{r}15,105 \\
(46.6)\end{array}$ & $\begin{array}{l}8,122 \\
(25.1)\end{array}$ & $\begin{array}{l}5,178 \\
(16.0)\end{array}$ & $\begin{array}{l}4.014 \\
(12.4)\end{array}$ & 32,419 & 20,481 \\
\hline December 1985 & $\begin{array}{l}30,185 \\
(58.7)\end{array}$ & $\begin{array}{l}9,816 \\
(19.1)\end{array}$ & $\begin{array}{l}6.578 \\
(12.6)\end{array}$ & $\begin{array}{r}4.806 \\
(9.4)\end{array}$ & 51,385 & 14,381 \\
\hline December 1990 & $\begin{array}{r}34,791 \\
(58.2)\end{array}$ & $\begin{array}{r}11,324 \\
(19.0)\end{array}$ & $\begin{array}{l}8,042 \\
(13.5)\end{array}$ & $\begin{array}{r}5.595 \\
(9.4)\end{array}$ & 59,752 & 13,756 \\
\hline
\end{tabular}

1.65Banks spread out first to rural areas and then building on this experience forayed further into unbanked areas. In 1977, banks were given the incentive of a license to open one branch in metropolitan and one in urban areas, as an incentive for opening four branches in rural

Table 3.23: Region-wise Distribution of Bank Branches in India

\begin{tabular}{|c|c|c|c|c|c|c|c|}
\hline As at End & Northern & North Eastern & Eastern & Central & Western & Southern & Total \\
\hline 1 & 2 & 3 & 4 & 5 & 6 & 7 & 8 \\
\hline June 1975 & $\begin{array}{l}3,174 \\
(17.1)\end{array}$ & $\begin{array}{r}275 \\
(1.5)\end{array}$ & $\begin{array}{l}2,189 \\
(11.8)\end{array}$ & $\begin{array}{l}2,795 \\
(15.0)\end{array}$ & $\begin{array}{l}3,873 \\
(20.9)\end{array}$ & $\begin{array}{l}6,269 \\
\langle 33.7\rangle\end{array}$ & $\begin{array}{l}18,575 \\
(100.0)\end{array}$ \\
\hline June 1960 & $\begin{array}{r}5.409 \\
(16.7)\end{array}$ & $\begin{array}{r}703 \\
(2.2)\end{array}$ & $\begin{array}{l}4.778 \\
(14.7)\end{array}$ & $\begin{array}{l}5,588 \\
(17.2)\end{array}$ & $\begin{array}{r}5.790 \\
(17.9)\end{array}$ & $\begin{array}{r}10,144 \\
(31.3\rangle\end{array}$ & $\begin{array}{l}32.412 \\
(100.0)\end{array}$ \\
\hline June 1985 & $\begin{array}{l}8.239 \\
(15.7)\end{array}$ & $\begin{array}{r}1,363 \\
(2.6)\end{array}$ & $\begin{array}{l}8.997 \\
(17.1)\end{array}$ & $\begin{array}{r}10,935 \\
(20.8)\end{array}$ & $\begin{array}{r}8.259 \\
(15.7)\end{array}$ & $\begin{array}{r}14,855 \\
(28.2\rangle\end{array}$ & $\begin{array}{r}52.638 \\
(100.0)\end{array}$ \\
\hline March 1990 & $\begin{array}{r}9.312 \\
(15.4)\end{array}$ & $\begin{array}{r}1,772 \\
(2.9)\end{array}$ & $\begin{array}{c}10,879 \\
(18.0)\end{array}$ & $\begin{array}{r}12,747 \\
(21.1)\end{array}$ & $\begin{array}{l}9.417 \\
(15.6)\end{array}$ & $\begin{array}{r}16,388 \\
(27.1\rangle\end{array}$ & $\begin{array}{l}60.515 \\
(100.0)\end{array}$ \\
\hline March 1991 & $\begin{array}{l}9.426 \\
(15.3)\end{array}$ & $\begin{array}{r}1,870 \\
(3.0) \\
\end{array}$ & $\begin{array}{r}11,362 \\
(18.4) \\
\end{array}$ & $\begin{array}{r}13,005 \\
(21.1)\end{array}$ & $\begin{array}{r}9.526 \\
(15.4) \\
\end{array}$ & $\begin{array}{r}16,535 \\
(26.8) \\
\end{array}$ & $\begin{array}{l}61,724 \\
(1000) \\
\end{array}$ \\
\hline \multicolumn{8}{|c|}{$\begin{array}{l}\text { 4. Eastern Reglon: Einar, Orissa, W. Ben } \\
\text { 5. Central Reglon : Machya Pradesh, Uta } \\
\text { 6. Western Reglon: Gujarat, Maharashtra } \\
\text { 7. Southern Reglon: Andrra Pradesh, Ke }\end{array}$} \\
\hline Source: $B$ & Basic statstical Retur & 5, varous issues. & & & & & \\
\hline
\end{tabular}

1.66 While the branch licensing policy was geared to tackle the urban bias of the banking sector, it was felt that this policy alone could not address the issue of rural credit. In order to ensure that rural deposits were not used to just increase urban credit, banks were directed that each rural and semi-urban bank should maintain a creditdeposit ratio of at least 60 per cent. The credit-deposit ratios for the banks in rural and semi-urban branches were carefully monitored.

1.67 The nationalisation of banks also led to a considerable reorientation of bank lending to accelerate the process of development, especially of the priority sectors of the economy, which had not previously received sufficient attention from the commercial banks. There was a greater involvement of banks in these and other socially desirable sectors. Credit planning under the guidance of the Reserve Bank was implicit all these years. However, after nationalisation in July 1969, this got a new impetus. Integration of credit planning with economic planning and policy was implemented with rigour by the Reserve Bank. A broad credit plan tuned to the overall plan and monetary requirements was drawn up, taking into account the national priorities, the anticipated pace of deposits accretion, general economic situation and likely developments in the different economic sectors. The plan had to provide for allocation for certain activities such as Government requirements and certain essential Government commercial operations like food procurement and buffer stock operations. Another important step was that of arriving at aggregate estimates for certain key sectors. Separate estimates were made for the busy and slack seasons, particularly in respect of sectors susceptible to seasonal changes. Against the background of this broad credit plan for the system as a whole, the individual credit plan of each bank was framed. Banks were asked to explore the scope for redeployment of existing credit and linking it to genuine productive purposes.

1.68 After the initiation of planned economic development in India, particularly in the 1960s, a high degree of emphasis was placed on deposit mobilisation by banks as one of the main ways through which the resources for the development of the economy could be enlarged. While the importance of deposit mobilisation in a resource scarce economy could hardly be overemphasised, it received a fresh impetus after nationalisation of banks. Immediately after the nationalisation, confidence in the banking sector increased, which was reflected in the sharp increase in the share of bank deposits in household savings and financial savings of households in their total saving. Conscious efforts were made to keep the deposit rates attractive. The period of nationalisation also coincided with the period of the Green Revolution and its benefits started flowing to the rural sector in terms of 
higher income. Rapid expansion of the branch network in rural areas, special emphasis on deposit mobilisation and rise in income levels propelled the growth of bank deposits (Table 3.24). The spread of banking and deposit mobilisation were the two most significant achievements of the nationalisation.

Table 3.24: Scheduled Commercial Banks -

Average Annual Growth Rates of Deposits

\begin{tabular}{lrrr} 
Period & $\begin{array}{r}\text { Growth Rates } \\
\text { of Demand } \\
\text { Deposits }\end{array}$ & $\begin{array}{r}\text { Growth Rates } \\
\text { of Time } \\
\text { Depost5 }\end{array}$ & $\begin{array}{r}\text { (Per cent) } \\
\text { Of Aggregate } \\
\text { Depost5 }\end{array}$ \\
\hline 1 & 2 & 3 & 4 \\
\hline $1950-65$ & 15.1 & 7.0 & 10.5 \\
$1965-70$ & 12.6 & 15.8 & 14.3 \\
$1970-75$ & 17.3 & 19.7 & 18.7 \\
$1975-80$ & 8.1 & 30.6 & 21.9 \\
\hline Source : Handbook of Statistics on the Inolan Economy, 2006-07 \\
(RB)).
\end{tabular}

1.69 The growth of deposit, in turn, was led by an increase in the savings rate (Table 3.25).

Table 3.25: Domestic Household Sector Savings
(Amount in Rupees crore)

1.70 Nationalisation was also visualised as a process that would entail large scale reorganisation of the nationalised banks with only one or two major banks acting as all-India banks catering to the wholesale market for credit and with a monopoly of foreign exchange business. All other banks were expected to be reorganised, merged, and re-packaged to create several entities which would work in specific regions and concentrate on agriculture, small industry and trade and the then credit-starved areas. However, such a restructuring did not take place and the status quo was maintained (Patel, 2002).

\section{Institution of Directed Credit and the Setting up of Regional Rural Banks}

1.71 Directed credit programme involving loans on preferential terms and conditions to priority sectors was a major tool of development policy in both developed and developing countries in the 1960s. An enunciation of the need to channel the flow of credit to certain sectors of the economy, known as the priority sectors with the social objectives in mind, was first discussed in India in July 1961. However, this was merely to indicate the preference to the banks as it was felt that if the banks on their own volition addressed this issue, there would be no need of stipulation of any target. Banks were expected to play a more active and positive role in aiding sectors such as agriculture and small scale industries. Once the main constraint of credit was resolved, these sectors were expected to do reasonably well. However, the bulk of bank advances continued to be directed to large and established business houses, while agriculture, SSI and exports did not receive adequate attention. As a result, the need was felt for imposing lending stipulations.

1.72 The Differential Rate of Interest (DRI) Scheme was also instituted in 1972 to cater to the needs of the weaker sections of the society and for their upliftment. The scheme targeted low income people in rural areas and gave them credit at concessional rate. The target group of this scheme was landless labourers, physically handicapped persons, orphanages, women's homes, scheduled castes and scheduled tribes who did not have any tangible security to offer and to the lending institutions. The minimum quantum of lending under this scheme for each bank was one per cent of its total advances of the previous year. The major problem faced by banks in administering this scheme as agents of the Government was proper identification of beneficiaries from among a large number of eligible borrowers so that the weakest among the eligible borrowers could benefit from the scheme.

1.73 Various measures initiated had a positive impact on lending to agriculture as the share of agricultural credit in total bank credit increased from 2.2 per cent in 1967 to 8.0 per cent in 1970-71 and further to 9.1 per cent in 1974-75 (Table 3.26). However, the improvement fell short of expectations. 


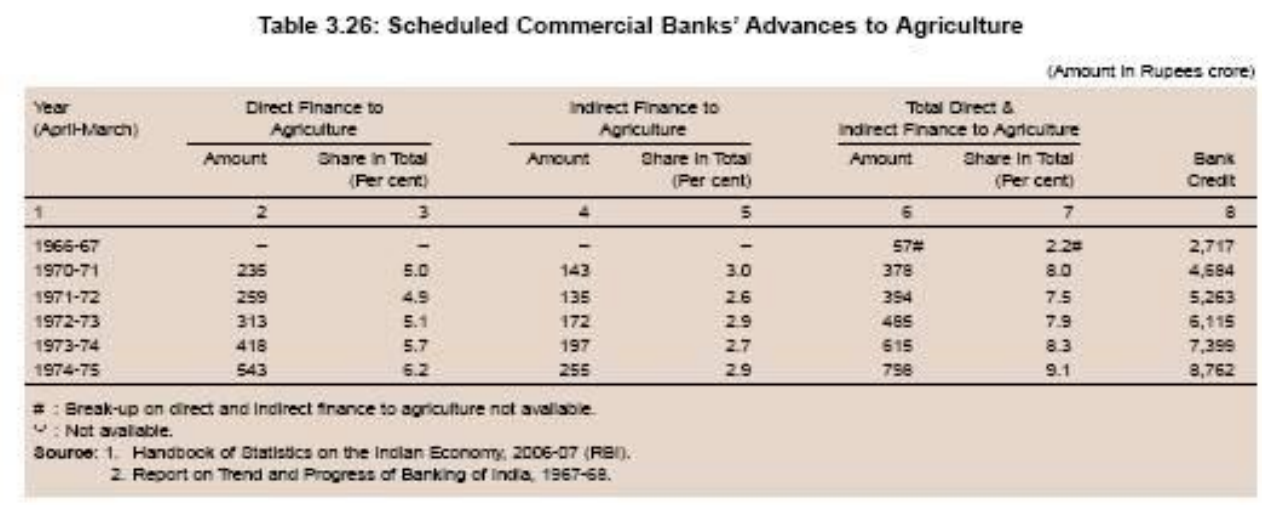

1.74 It was felt that this was mainly because commercial banks were not tuned to the needs and requirements of small and marginal farmers, while the co-operatives lacked resources to meet the expected demand. The need, therefore, was felt of a separate banking structure, capable of combining the local feel and familiarity of rural problems characteristic of co-operatives and the professionalism and large resource base of commercial banks. While the idea of starting rural banks was first suggested by the Banking Commission (1972), action along these lines was initiated after the 'Twenty Point Programme' or 'New Economic Programme' of the Government of India launched in the mid-1970s. The Regional Rural Banks Ordinance was promulgated on September 26, 1975, which was subsequently replaced by the Regional Rural Banks Act on February 9, 1976. Regional Rural Banks (RRBs) were set up with a view to developing the rural economy by providing credit for the purpose of development of agriculture, trade, commerce, industry and other facilities, particularly to the small and marginal farmers, agricultural labourers, artisans and small entrepreneurs. They were expected to 'combine the rural touch and local feel with the modern business organisation'.

1.75 The Differential Rate of Interest (DRI) Scheme was modified to allow sponsor banks to route the DRI advances through RRBs on a refinance basis, in addition to the routing of such advances on an agency basis. The refinance to RRBs carried a rate of interest at 2 per cent per annum and the amount of refinance so provided was taken into account by sponsoring banks for the purpose of the target of 1 per cent of the lendings under the scheme.

1.76 In 1978, commercial banks and RRBs were directed to charge a flat rate of 9 per cent on all priority sector loans, irrespective of size. It was recognised that cost of credit, rather than access, was the key constraint facing the rural poor. The policy was to free the vulnerable rural population from the local moneylenders by enhancing the spread of organised credit. The results of nationalisation of banks and introduction of directed credit programmes and other initiatives were extremely encouraging. The share of rural branches increased sharply from 17.6 per cent in 1969 to 58.2 per cent in 1990. The share of the non-institutional sources (professional moneylenders, landlords and agriculturist moneylenders) in rural credit declined with the rise in the spread of institutional banking to rural areas. The share of rural credit in total credit outstanding and rural deposits in total deposits also increased significantly. The credit-deposit ratio in rural areas increased from 37.6 per cent in 1969 to 60.6 per cent in 1981 and remained at that level in 1990 (Table 3.27).

Table 3.27: Growth of Rural Banking in India - 1969-1990

\begin{tabular}{|c|c|c|c|c|c|c|c|c|}
\hline \multirow[b]{2}{*}{ As at End } & \multicolumn{2}{|c|}{$\begin{array}{c}\text { Number of Bank } \\
\text { Orfices }\end{array}$} & \multicolumn{2}{|c|}{ Credit-Outstanding } & \multicolumn{2}{|c|}{ Deposits - Outstancing } & \multicolumn{2}{|c|}{$\begin{array}{l}\text { Credit-Deposit } \\
\text { Rato (per cent) }\end{array}$} \\
\hline & Rural & $\begin{array}{l}\text { \% of } \\
\text { Total }\end{array}$ & $\begin{array}{r}\text { Rural } \\
\text { (Rs. crore) }\end{array}$ & $\begin{array}{l}\text { \%, of } \\
\text { Total }\end{array}$ & $\begin{array}{r}\text { Rural } \\
\text { (R5. crore) }\end{array}$ & $\begin{array}{l}\text { \% of } \\
\text { Total }\end{array}$ & Rural & $\begin{array}{c}\text { All } \\
\text { Indla }\end{array}$ \\
\hline 1 & 2 & 3 & 4 & 5 & 6 & 7 & 8 & 9 \\
\hline June 1969 & 1,443 & 17.6 & 115 & 3.3 & 306 & 6.3 & 37.6 & 71.9 \\
\hline Decenber 1981 & 19,453 & 51.2 & 3,600 & 11.9 & 5.939 & 13.4 & 60.6 & 68.1 \\
\hline March 1990 & 34,867 & 58.2 & 17,352 & 14.2 & $28,6 \mathrm{Cg}$ & 15.5 & 60.7 & 66.0 \\
\hline
\end{tabular}

1.77 On the whole, scheduled commercial banks' advances to agriculture, exports and small scale industries showed a significant rise, while those to industry declined (Table 3.28). 
Table 3.28: Distribution of Bank Credit to Various Sectors - Outstanding

\begin{tabular}{|c|c|c|c|c|c|}
\hline & & & & & (Rupees crore \\
\hline As at End & Industry & Smal-scale incustry & Exports & Agriculture & Gross Bank Credt \\
\hline 1 & 2 & 3 & 4 & 5 & 6 \\
\hline March 1963 & $\begin{array}{r}2068 \\
(67.5)\end{array}$ & $\overline{-}$ & $\overline{-}$ & $\begin{array}{r}67 \\
(2.2)\end{array}$ & $\begin{array}{l}2135 \\
(100)\end{array}$ \\
\hline March 1980 & $\begin{array}{r}8269 \\
(38.9)\end{array}$ & $\begin{array}{r}2635 \\
(124)\end{array}$ & $\begin{array}{l}1640 \\
(7.7)\end{array}$ & $\begin{array}{r}2767 \\
(13.0)\end{array}$ & $\begin{array}{r}21235 \\
(100)\end{array}$ \\
\hline June 1989 & $\begin{array}{l}33625 \\
\{37.5\rangle\end{array}$ & $\begin{array}{l}13697 \\
(15.3)\end{array}$ & $\begin{array}{r}6556 \\
(7.3)\end{array}$ & $\begin{array}{l}14146 \\
(15.8)\end{array}$ & $\begin{array}{r}89654 \\
(100)\end{array}$ \\
\hline
\end{tabular}

\section{Further Strengthening of the Micro Controls}

1.78 The need to direct credit according to the plan priorities led to various micro controls which took the form of specifications regarding sectoral deployment of credit and setting of interest rates for deposits and loans. In order to garner resources for growth, it was felt that the banking system should play a key role in mobilising deposits. While the spread of bank branch network helped to some extent, the deposit interest rate, it was believed, had to be attractive for such effort to be successful. However, higher deposit rates meant a higher cost of credit to the borrower. While the lending rate for the priority borrowers was at a concessional rate, the rates to the non-priority borrowers increased due to cross-subsidisation. A ceiling rate on export credit was also prescribed in March 1968 to encourage the flow of credit to the sector. Effective March 1969, floors/ceiling was also used to provide sufficient funds to certain economic activities/borrowers. The basic idea was to provide sufficient funds for productive activities to promote growth. The need for resources for planned development gradually increased the Government borrowing and with this, interest rate flexibility became an issue as it affected the cost of borrowing.

1.79 The oil shock in the early 1970s led to severe inflationary pressures. In order to combat the situation, effective June 1, 1973, the Reserve Bank imposed a minimum lending rate of 10 per cent on all loans, except for the priority sector. The oil shock led to a rise in the import bill and tremendous pressure on the balance of payments. Therefore, it was considered desirable to provide a boost to the exports. Export credit was, therefore, moved into the priority list (outside the purview of quantitative restrictions on credit). With a view to enhancing the resources with the banking system, an upward adjustment in the term deposit rates of longer maturities was undertaken between the years 1973 to 1974. In April 1974, interest rates on deposits were increased for various categories pushing up the cost of funds for the banking sector. In view of the inflationary situation, the minimum rate chargeable against selective credit controls was also raised in July 1974.

1.80 The commercial banks charged very high rates in some cases and the incidence of such high rates fell even on the small borrowers. To address this issue, the Reserve Bank in 1976 prescribed the maximum rate for bank loans in addition to the minimum lending rates. Smaller banks with demand and time liabilities of Rs. 25 crore to Rs. 50 crore, were given some flexibility.

1.81 In June 1977, the structure of interest rates on deposits was rationalised and the spread between short and long-term rates widened. A distinction was made between saving accounts, which were functionally savings oriented, and others which were transaction oriented, by bifurcating the savings accounts into two categories. From July 1977, savings accounts without cheque facilities were paid 5 per cent interest, while those with cheque facilities earned a lower rate of 3 per cent. However, on March 1978, these two accounts were merged into a single saving deposit account with limited cheque facilities and interest was allowed at 4.5 per cent. Significant modifications were brought about in the interest rates structure on March 2, 1981, reflecting in part the response to the persistent inflationary pressures. This was because the structure of lending rates then prevalent offered inadequate gradation in the rates charged to various categories of beneficiaries in the priority sectors, although a plethora of rates prevailed. A series of anomalies developed and these were addressed by further regulation. For instance, several categories of advances to the priority sectors, only ceiling rates of interest were indicated. This allowed different banks to charge different rates for the same kind of advances in a particular area causing substantial horizontal inequity. The alterations in lending rates brought in further controls, as the earlier specification was a permissible range which was replaced by specific fixed rates. Four distinct rate categories relating to the lending to priority sectors were specified, viz., 12.5 per cent, 15 per cent, 17.5 per cent and 19.5 per cent, in order to ensure uniformity of rates among banks for the same category of advances particularly in the case of the priority sectors. Earlier, small banks were permitted to charge higher rates of interest. Some rationalisation was achieved in lending rates from 1991 when the maximum lending rate was made applicable uniformly to all the scheduled commercial banks, irrespective of their size.

1.82 With the increased proliferation of directed credit arrangements, multiple interest rate prescriptions based on a variety of criteria (such as, economic activity, commodity, location and specific group of borrower, among others) and the resultant cross subsidisation created a very complex administered interest rate structure with virtually no role for market forces to play in pricing and allocation of credit.

1.83 The need to contain inflationary pressures also made the Reserve Bank to use some of the existing 
qualitative instruments such as selective credit control. This complicated bank lending activity as there were a large number of stipulations to be adhered to. The banking sector also had to operate within the constraints imposed by restrictions on the credit-deposit ratio imposed by the Reserve Bank to contain banks' lending activities to their own resources. This was supplemented by the instrument of moral suasion. The requirements of various schemes and detailed provisions complicated the banks' job. For instance, differential interest rates were set by the central bank for various purposes and according to the needs of borrowers in an effort to align the Reserve Bank's policies to the Government's developmental goals. Micro allocation of credit and credit subsidies to preferred sectors were undertaken in order to support the Government's growth initiatives. The result was multiplication of the constraints within which the banks had to operate. Some help was provided in terms of the discretionary support by the Reserve Bank, like in most developing countries, through the use of instruments such as refinance on preferred activities, including credit to agriculture, co-operative banks and export credit, among others. Such refinancing had two effects, a direct credit effect and an announcement effect. They were useful in helping the banks to cover their costs for the preferred activity. However, like all subsidybased quasi-fiscal regulations, such measures further distorted the markets. Such measures enlarged the monetary base, altered the credit multiplier and complicated monetary management. The plethora of compulsions on the banking sector translated into a complex set of micro regulations and led to financial repression. This dirigiste approach to economic management led to crowding out of private enterprises as the increasing share of credit flows was mopped up by the Government and public enterprises. Moreover, these quasi-fiscal policies gradually affected commercial banks' balance sheets by affecting their profitability. Besides, non-performing assets of banks increased sharply. Decline in profitability and increase in NPLs also impacted the soundness of the banking sector as banks were unable to plough back their profits as detailed in the subsequent sections.

\section{Inventory Norms for Industry}

1.84 The administered interest rate structure perpetuated the excess demand for credit. There was also a growing concern regarding the lack of financial planning by the corporates and their excessive reliance on bank funds. There was a conflict of interest between corporate policy and planned objectives. During periods of rising prices, corporates tended to maximise their profits by speculative hoardings of finished goods as the costs of such hoarding (in terms of interest paid for holding inventories) was more than offset by the sharp rise in prices of finished goods. ${ }^{28}$ The Reserve Bank, in view of the plan priorities, had to curb any tendency towards speculative hoarding by using banks' funds. There was also an issue of building up an information system to provide the Reserve Bank with requisite information about the operations of the banks and the borrowers. It was also felt necessary to have a channel of communication between the Reserve Bank and the banking sector so as to serve as a devise of credit supervision and improvement in the responsiveness of the banking system to policy changes introduced from time to time. These omnibus issues relating to credit to industry needed to be addressed in an integrated manner. Accordingly, it was decided to refer these issues to a committee (Chairman: Shri Prakash Tandon) to take an integrated view of the several problems in framing the guidelines for supervision and follow-up of bank credit. Based on the recommendations of the Tandon Committee, various parameters/norms were prescribed in 1975 for inventory and receivables, approach to lending, style of credit and follow up. The three methods of lending proposed by the committee envisaged different levels of contribution from the long-term funds of the borrowing units with a view to progressively reducing the dependence of the corporates on short-term bank borrowings. ${ }^{29}$ Banks were asked to initiate immediate action and to place all borrowers with aggregate credit limit from the banking system in excess of Rs.10 lakh on the first method of lending, whereby 25 per cent of the working capital gap, i.e., the difference between current assets and current liabilities, excluding bank finance, was required to be funded from long-term sources. Maximum permissible bank finance (MPBF) also became the basis of consortium arrangement, which was in existence from 1972. Guidelines were also issued to commercial banks for supervision of credit for ensuring its proper use.

1.85 The system of working of the cash credit system, especially the gap between sanctioned credit limits and utilisation was reviewed in $1980 . \frac{30}{}$ It was decided to continue the system of lending by way of cash credit, loans and bills. However, the cash credit system was streamlined. Periodic review of limits (at least once a year) fixed under the system was made compulsory in respect of all borrowal accounts enjoying working capital limit of Rs.10 lakh and over. The contribution from borrowers towards working capital out of their long-term sources was to be in the second method of lending suggested by the Tandon Group, i.e., not less than 25 per cent of the current assets required for the estimated level of production, which would give a minimum current ratio of 1.33:1 (as against 25 per cent of working capital gap, i.e., total current assets minus current liabilities other than bank borrowing). In case a borrower was not in a position to comply with this requirement immediately, the existing need-based credit limits already enjoyed by the borrower was not to be curtailed. The excess over the credit limit permissible to the borrower was to be segregated and treated as working capital term loan (WCTL), which was to be repayable in half-yearly instalments within a definite period not exceeding 5 years. The WCTL 
was to carry interest rate not less than the rate charged for the relative cash credit, and banks could, at their discretion, charge a higher rate of interest not exceeding the ceiling. In addition, suitable provisions were required to be made for charging the penal rate of interest in the event of any defaults in the timely repayment of WCTL. If additional limits became necessary on account of increased production, banks were asked to ensure that the WCTL component was not enhanced and additional limits were allowed on the basis of an incremental current ratio of 1.33:1. Separate limits were to be fixed, wherever feasible, for normal and peak level credit requirements indicating the periods during which the relative limits were to be utilised by borrowers. After introduction of these norms, inventories held declined due to careful inventory management by firms (Singh et al., 1982). On a broader level, company finance data also suggested a sectoral shift in bank lending in favour of small scale industries.

\section{Nationalisation of Banks in the 1980}

1.86 Some private banks were observed to suffer from some governance problems. Further, there was a need to address the need of credit delivery in greater measure. Accordingly, six banks, viz, Andhra Bank, Corporation Bank, New Bank of India, Oriental Bank of Commerce, Punjab and Sind Bank, and Vijaya Bank with deposit liabilities of Rs. 200 crore and above, were

nationalised in April 1980. With the nationalisation of these six banks by the Government, the number of public sector banks, including the State Bank of India and its associate banks rose to 28 in April 1980, constituting 91 per cent deposits of the banking sector.

\section{Increase in Statutory Pre-emptions and their Impact on the Banking Sector}

1.87 One of the outcomes of the substantial expansionary plan expenditure during the 1970s and the 1980s was that the Government's budget expanded and the banking sector was increasingly used for financing fiscal deficits. The fiscal deficit to GDP ratio increased steadily from 3.1 per cent of GDP in 1970-71 to 5.8 per cent in 1980-81 and further to 7.9 in 1990-91 (Table III.29)

Table 3.29: Select Fiscal Indicators of the Central
Government

1.88 The growth inflation trade-off was more evident during this phase as the high investment that was made as a part of the Five Year Plans was supported by deficit financing that was inflationary. The Government borrowed from the Reserve Bank by way of automatic monetisation of deficit by adhoc Treasury Bills, which resulted in an increase in reserve money and money supply. In order to counter the impact of deficit financing that fuelled excess money growth, the Reserve Bank was required to raise the cash reserve ratio (CRR) frequently. The CRR was gradually raised from 5.0 per cent in June 1973 to 15.0 per cent by July 1989 (Table 3.30). Besides, an additional CRR of 10.0 per cent was also introduced effective November 1983. The idea was to reduce the capacity of the banks to create credit by affecting the credit multiplier. At the macro level, credit rather than money supply was viewed as the factor affecting demand.

\begin{tabular}{|c|c|c|c|}
\hline Etectlve Dare & $\begin{array}{l}\text { Cosh Resene } \\
\text { Rello: }\end{array}$ & Emective Date & $\begin{array}{l}\text { Cash Reserve } \\
\text { Rasio: }\end{array}$ \\
\hline June 29, 1973 & 5.00 & June 11,1982 & 7.00 \\
\hline Sestenteer 08,1973 & 6.00 & Mby 27,1983 & 7.50 \\
\hline Sestenber 22, 1973 & 7.00 & Juby 29,1983 & 800 \\
\hline aty or, 1974 & 5.00 & Awguat 27,1963 & 8.50 \\
\hline Decentber 14,1974 & 4.50 & Noventioer 12,1983 & 8.50 \\
\hline December 28,1974 & 4.00 & Feoruary o4, 1994 & 900 \\
\hline Sestember 04,1976 & 5.00 & October 27,1964 & 900 \\
\hline Novenber 13,1976 & 6.00 & Decenter 01, 1994 & 900 \\
\hline January 14, 1977 & 6.00 & Octaber 26, 1995 & 2000 \\
\hline vaty 01,1978 & 6.00 & Novendider 22, 1996 & 900 \\
\hline ane 05, 1979 & 6.00 & Feorusy 23, 1987 & 950 \\
\hline aty 31,1981 & 6.50 & $\mathrm{Mgy} / 23,1967$ & 950 \\
\hline Augus: 21, 1981 & 7.00 & Oclober 24, 1997 & 1000 \\
\hline November 27,1981 & 7.25 & Apdi 23, 1998 & 1000 \\
\hline December 25,1961 & 7.50 & July 2, $198 \mathrm{a}$ & 10.50 \\
\hline January 29, 1982 & 7.75 & July 30,1983 & 11.00 \\
\hline Aonl 09, 1992 & 7.25 & Juty 1, 1969 & 1500 \\
\hline
\end{tabular}


1.89 The banking sector also became a captive source of funds by means of the statutory liquidity ratio (SLR), the proportion of net demand and time deposits that banks were required to maintain in India in cash, gold and unencumbered approved securities. Between 1970 and 1991 the SLR was revised by 12.5 percentage points. Although the SLR was introduced in 1949 as a prudential requirement, it became an instrument of financing the deficit of the central and state Governments as also certain public sector entities (Table 3.31). Thus, by 1991, 63.5 per cent resources of the banking sector were pre-empted in the form of SLR and CRR.

\begin{tabular}{|c|c|}
\hline Ellecthe Date & atabatory Loularly Fatjo * \\
\hline Feonuary 05, 1970 & 26.00 \\
\hline Apri 24,1970 & 27.00 \\
\hline Aupuat 28, 1970 & 2800 \\
\hline Auguat 04,1972 & 2900 \\
\hline November 17,1972 & 30.00 \\
\hline December 08,1973 & 3200 \\
\hline Juby a1, 1974 & 3300 \\
\hline December 01, 1978 & 34.00 \\
\hline aeptember 25, 1961 & 34.50 \\
\hline Octaber 30, 1991 & 3500 \\
\hline July 28,1934 & 35.50 \\
\hline Septenber 01, 1964 & 36.00 \\
\hline Jure 08, 1985 & 3650 \\
\hline Juty 05, 1985 & 37.00 \\
\hline April 25, 1987 & 37.50 \\
\hline January 2,1988 & 38.00 \\
\hline Sepsember 22,1990 & 3850 \\
\hline
\end{tabular}

1.90 The increase in CRR/SLR per se might not have affected the banking sector, had the requirements been adequately remunerative. However, banks earned less than market rate of interest on eligible CRR balances (over the then statutory minimum of 3 per cent), while the yield on Government securities was far below the saving deposit interest rates, let alone the lending interest rates. For instance, up to 1981-82, yield on Government Securities was lower than the interest rate paid by banks on deposits of 1 to 3 years maturity. Although the yield on Government securities thereafter was raised, it remained significantly lower than the lending interest rates of banks (Table 3.32).

\begin{tabular}{|c|c|c|c|c|c|c|c|c|}
\hline \multirow{4}{*}{ (End-March) } & & & & & & & (per o & ant per annum) \\
\hline & \multicolumn{7}{|c|}{ Commerclal Bank Rates } & \multirow{3}{*}{$\begin{array}{r}\text { Central } \\
\begin{array}{r}\text { Government } \\
\text { Securtles } \\
\text { Primary } \\
\text { Yield }\end{array} \\
\begin{array}{r}\text { Weighted } \\
\text { average: }\end{array}\end{array}$} \\
\hline & \multicolumn{3}{|c|}{ Depos: interest Rates } & \multicolumn{4}{|c|}{$\begin{array}{l}\text { Lending Interest Rates } \\
\text { Key Lending rates as prescribed by RE! } \\
\text { (All commercial banks including SEI) }\end{array}$} & \\
\hline & 1 to 3 yrt. & 3 to 5 yrs. & $\begin{array}{l}\text { More than } \\
5 \text { yrs }\end{array}$ & $\begin{array}{c}\text { SBI Advance } \\
\text { Rate" }\end{array}$ & $\begin{array}{l}\text { Celling Rate } \\
\text { General }\end{array}$ & $\begin{array}{l}\text { Minimum } \\
\text { Rate } \\
\text { General }\end{array}$ & $\begin{array}{r}\text { Minimum } \\
\text { Rate } \\
\text { Selective } \\
\text { Credit } \\
\text { Contro }\end{array}$ & \\
\hline 1 & 2 & 3 & 4 & 5 & 6 & 7 & 8 & 9 \\
\hline 1971 & $6.00-6.5$ & 70 & 7.25 & $7.0-8.5$ & - & - & - & - \\
\hline 1972 & 6.0 & 6.5 & 7.25 & 8.5 & - & - & 12.0 & - \\
\hline 1973 & 60 & 6.5 & 7.25 & 8.5 & - & - & 12.0 & - \\
\hline 1974 & 6.0 & 7.0 & 7.25 & $8.5-9.0$ & - & $100-11.0$ & $12.00-13.0$ & 5.18 \\
\hline 1975 & $6.75-8.0$ & $7.75-9.0$ & $8.60-10.00$ & $9.0-13.5$ & - & $11.0-13.0$ & $14.00-15.0$ & 5.67 \\
\hline 1976 & 8.0 & 90 & 10.00 & 140 & 16.50 & 12.5 & $14.00-15.0$ & 5.79 \\
\hline 1977 & 8.0 & 90 & 10.00 & 140 & 16.50 & 12.5 & $14.00-15.0$ & 5.73 \\
\hline 1978 & 60 & 8.0 & 9.00 & 130 & 15.00 & 12.5 & $14.00-15.0$ & 5.85 \\
\hline 1979 & 6.0 & 7.5 & 9.00 & 13.0 & 15.00 & 12.5 & $14.00-15.0$ & 5.84 \\
\hline 1960 & 7.0 & 8.5 & 1000 & 16.5 & 18.00 & 12.5 & $15.50-18.0$ & - \\
\hline 1981 & $7.50-8.5$ & 100 & 10.00 & 16.5 & $19 . \angle 0-19.50$ & 13.5 & $16.70-19.5$ & 7.03 \\
\hline 1982 & $8.00-9.0$ & 100 & 10.00 & 16.5 & 19.50 & - & $17.50-19.5$ & 7.29 \\
\hline 1983 & $8.00-9.0$ & 10.0 & 11.00 & 16.5 & 19.50 & - & $17.50-19.5$ & 8.36 \\
\hline 1984 & $8.00-90$ & 100 & 11.00 & 16.5 & 18.00 & - & $16.50-18.0$ & 9.29 \\
\hline 1965 & $8.00-9.0$ & 10.0 & 11.00 & 16.5 & 18.00 & - & $16.50-18.0$ & 9.96 \\
\hline 1986 & $8.50-9.0$ & 100 & 11.00 & 16.5 & 17.50 & - & $16.50-17.5$ & 11.08 \\
\hline 1987 & $8.50-9.0$ & 10.0 & 11.00 & 16.5 & 17.50 & - & $16.50-17.5$ & 11.38 \\
\hline 1988 & $9.00-10.0$ & 10.0 & 10.00 & 16.5 & 16.50 & - & 16.5 & 11.25 \\
\hline 1989 & $9.00-100$ & 10.0 & 10.00 & 16.5 & - & 16.0 & 16.0 & 11.40 \\
\hline 1990 & $9.00-100$ & 10.0 & 1000 & 16.5 & - & 16.0 & 16.0 & 11.49 \\
\hline
\end{tabular}

3.115 This phase was marked by several controls (Box III.1). 
3.116 The proliferation of directed credit arrangements, administered structure of interest rates and increase in statutory pre-emptions all had an adverse impact on banks' profitability. The return on assets (RoA) of banks declined sharply between 1975 and 1985 before improving marginally in the second half of the 1980s as a result of several measures initiated towards liberalisation as detailed subsequently in this section. The deterioration in profitability was observed across all bank groups, although it was more pronounced in respect of SBI group (Table 3.33).

\section{Box III.1}

\section{Major Controls Introduced: 1967 to 1991}

1967 Social control over banks announced in December 1967 with a view to securing a better alignment of the banking system to the needs of economic policy. 1968 National Credit Council (NCC) was set up in February 1968 to assist the Reserve Bank and the Government to allocate credit according to plan priorities.

1969 Fourteen banks with deposits of over Rs.50 crore were nationalised.

1969 The Lead Bank Scheme was introduced with a view to mobilising deposits on a massive scale throughout the country and also for stepping up lending to the weaker sections.

1972 Concept of priority sector was formalised. Specific targets were set out in November 1974 for public sector banks and in November 1978 for private sector banks. 1972 The Differential Rate of Interest (DRI) Scheme was instituted in 1972 to cater to the needs of the weaker sections of the society and for their upliftment. 1973 A minimum lending rate was prescribed on all loans, except for the priority sector.

1973 The District Credit Plans were initiated.

1975 Banks were required to place all borrowers with aggregate credit limit from the banking system in excess of Rs.10 lakh on the first method of lending, whereby 25 per cent of the working capital gap, i.e., the difference between current assets and current liabilities, excluding bank finance, was required to be funded from long-term sources.

1976 The maximum rate for bank loans was prescribed in addition to the minimum lending rates.

1980 The contribution from borrowers towards working capital out of their long-term sources was placed in the second method of lending, i.e., not less than 25 per cent of the current assets required for the estimated level of production, which would give a minimum current ratio of 1.33:1 (as against 25 per cent of working capital gap stipulated under the norms prescribed in 1975).

1980 Six Banks with demand and time liabilities greater than Rs.200 crore as on March 14, 1980, were nationalised on April 15, 1980. 1988 Service Area Approach (SAA) was introduced, modifying the Lead Bank Scheme.

1989 The CRR was gradually raised from 5.0 per cent in June 1973 to 15.0 per cent by July 1989 .

1991 The SLR was raised by 12.5 percentage points from 26 per cent in February 1970 to 38.5 per cent in September 1990.

\section{Reduction in Micro Controls, Early Steps towards Liberalisation and Strengthening of Banks}

3.117 A series of small steps were initiated towards liberalisation in several sectors of the economy in the mid1980s. For instance, quota and ceilings were relaxed and there was liberalisation of imports. In many ways the first wave of financial liberalisation also took place in the second half of the 1980s. As part of this process, the Reserve Bank took a number of initiatives towards liberalisation. With a view to providing some relief to borrowers with a good credit record and at the same time to provide flexibility to banks in the matter of interest rates charged to their borrowers, the ceiling on all lending interest rate was removed, subject to a minimum rate. Banks were given discretion to charge differential rates judiciously to categories other than those being provided credit at concessional lending rates. A number of measures were also taken to bring short-term interest rates in better alignment with other interest rates in the system. In the Government securities market, coupon rates on government bonds were gradually increased to reflect demand and supply conditions.

3.118 The process of expansion in the banking network in terms of geographical coverage and heightened controls affected the quality of banks assets and strained their profitability. In response to these developments, a number of measures were undertaken in the mid 1980s for consolidation and diversification and, to some extent, deregulation of the financial sector. The consolidation measures were aimed at strengthening banks' structures, training, house-keeping, customer services, internal procedures and systems, credit management, loan recovery, staff productivity and profitability. Certain initiatives were also taken to impart operational flexibility to banks. 3.119 The Indian banking sector in the early 1980s faced competition from the stock and bond markets, nonbanking financial companies and mutual fund schemes. Many companies made successful forays in the equity market and floated bonds with remunerative yields with and without tax incentives. The small saving instruments (like the National Savings Certificates VI issue) also became popular as they offered tax benefits. This turned savers away from the bank deposits that offered no such features and offered very low or negative real interest rate to the depositors. The banking sector was largely constrained as the Banking Regulation Act 
did not permit it to undertake non-banking activities. As a result, the share of deposits in household sector's savings declined while that of deposits with non-banking companies and in small savings instruments floated by the Government increased. The variety in investment opportunities available to individual as well as corporate depositors was the main reason of this process of disintermediation of the banking industry (see Chapter IV for details). Like in most other countries, banks in India were not allowed to undertake activities that traditionally did not pertain to banking per se. The Banking Regulation Act, 1949 defined "banking" as the "accepting, for the purpose of lending or investment, of deposits of money from the public, repayable on demand or otherwise, and withdrawable by cheque, draft, order or otherwise". It prohibited banks from investing in non-banking assets. Banks, thus, historically operated in areas such as banking services, provision of remittance service, collection of cheques and bills of exchange, issue of guarantees, opening letters of credit and leasing safe deposit lockers.

3.120 In a definitive step towards liberalisation, the Banking Regulation Act was amended in 1984 with a view to addressing the decline in the role of banks due to financial disintermediation. Banks were permitted to undertake merchant banking activities through subsidiaries. Many banks accordingly set up subsidiaries for undertaking merchant banking and securities market related activities, equipment leasing, hire purchase, mutual funds, housing finance, and venture capital. Diversification of banking activities helped the banks to widen their business activities and raise their profitability through the opportunity to gain non-interest income. This was a symbiotic process, as the industrial sector was also morecomfortable with their banks handling these activities. As a result of this deregulation, there were some distinct risks that had to be countered. The Reserve Bank addressed these by encouraging banks to engage in securities business through subsidiaries, thereby putting in place firewalls between traditional banking and non-traditional activities. The Reserve Bank also prohibited cross-holdings with industrial groups to minimise connected lending.

3.121 The health of the banks also became a primary concern to the Reserve Bank. Most of the nationalised banks had a weak capital base. In order to strengthen the capital base of banks, a scheme was evolved by the Reserve Bank in consultation with the Government to augment the capital base of nationalised banks. The Government decided to contribute a sum of Rs.2,000 crore for allocation among 20 nationalised banks during the Seventh Five Year Plan (April 1985-March 1990). The objective behind this scheme of augmentation of capital base was to strengthen the owned funds to deposit ratio with the aim of reaching a level of 2.5 per cent. The amount allocated was simultaneously invested in non-negotiable special securities bearing interest rate of 7.75 per cent per annum.

3.122 With a view to strengthening the banking system, the Health Code System was introduced in 1985, which classified bank loans according to their performance. Under the Health Code System, the commercial banks were required to classify their advances portfolio under the uniform grading system based on the quality or health of individual advances in eight categories. This system consisted of 8 codes. Of these, nos. 5 to 8 were deemed as non-performing assets. These comprised (a) debts recalled; (b) suit-filed accounts, i.e., where legal action or recovery proceedings had been initiated; (c) decreed debts, i.e., where suits had been filed and decree obtained; and (d) debts classified as bad and doubtful. As a prudent accounting practice of cessation of interest application on non-performing loans, banks were advised in May 1989 not to charge and take to their income account interest on loans classified under the health code classification 6, 7 and 8 from the quarter in which the individual accounts were classified under their categories. As a further step towards greater transparency in bank accounts and with a view to ensuring that recognition of income was done on a more prudential basis, banks were advised in October 1990 that from the accounting year 1990-91, they should not charge and take to their income account, interest on advances classified under the Health Code classification 5 also from the quarter in which individual accounts were so classified. Application of interest under the Health Code classification 4 was left to the discretion of banks based on the availability of adequate security and prospects of realisability of security.

3.123 To sum up, major issues faced at the beginning of this phase were the strong nexus between banks and industry, as a result of which agriculture was ignored. The focus in this phase was to break the nexus and improve the flow of credit to agriculture. The main instruments used for this purpose were nationalisation of major banks in the country and institution of directed credit in the form of priority sector lending. The achievements during the nationalisation phase were extensive, varied and widely acknowledged. The nationalisation of banks in 1969 and again in 1980 brought a large segment of the banking business under government ownership. In the post-nationalisation phase, the country was able to build up financial infrastructure geographically wide and financially diverse to accelerate the process of resource mobilisation to meet the growing needs of the economy. The nationalisation of banks in 1969 was a major step to ensure timely and adequate credit to all the productive activities of the economy. It was designed to make the system reach out to the small man and the rural and semi-urban areas and to extend credit coverage to sectors then neglected by the banking system, in place of what was regarded as a somewhat oligopolistic structure where the system served mainly the urban and the industrial sectors and where the grant of credit was seen as an act of patronage 
and receiving it as an act of privilege. ${ }^{31}$ As at end-December 1990, there were 59,752 branches of commercial banks (including RRBs) in the country, of which 34,791 (58.2 per cent) were in rural areas. As a result of rapid branch expansion witnessed beginning from 1969, the average population per bank office, which was 65,000 in 1969, declined to 14,000 at end-December 1990. This reflected substantial efforts made towards spread of

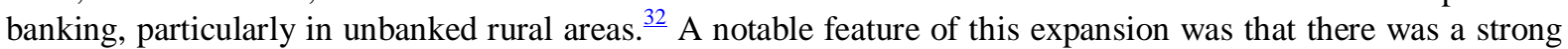
convergence across regions. Bank branches in unbanked locations really accelerated after the 1:4 licensing rule of 1977, as between 1977 and 1990 more than three-fourths of the bank branches that were opened were in unbanked locations.

3.124 Large branch expansion also resulted in increase in deposits and credit of the banking system from 13 and 10 per cent of GDP, respectively, in 1969 to 38 per cent and 24 per cent, respectively, by 1991. New branches opened helped considerably in deposit mobilisation and the evidence suggested that of the incremental deposits a large proportion was from the branches opened after 1969. The share of rural deposits in total deposits increased from 3 per cent in 1969 to 16 per cent in 1990. The share of credit to the rural sector in total bank credit increased from 3.3 per cent in 1969 to 14.2 per cent in 1990. The banking sector met the credit needs of the economy subject to the requirements of sectoral allocation and rendered support to the planning authority in efficient and productive deployment of investible funds so as to maximise growth with stability and social justice.

3.125 In the 1970s and the 1980s, the growing fiscal deficit and increased automatic monetisation, whereby the Government could borrow from the Reserve Bank with the help of ad hoc Treasury Bills, resulted in a rise in reserve money and money supply. To counter reserve money growth, the Reserve Bank was required to raise the cash reserve ratio (CRR). Although resource mobilisation by the banking system increased sharply, the demands made on the banking system also increased. In order to finance the increase in fiscal deficit of the Government, the Reserve Bank was forced to increase the SLR of banks. At one point of time, 63.5 per cent of the resources of the banking sector were pre-empted by way of CRR and SLR and such deployments were not adequately remunerated. In view of increased demand for funds from various quarters, attempts were made to bring some financial discipline on the part of corporates. However, norms stipulated for the purpose were found to be too rigid. The traditional sectors, in particular, faced overall credit restrictions during periods of tight monetary policy. As a result, the traditional sectors started seeking funds from sources other than the banking system such as capital market and raising deposits directly from the public, leading to disintermediation. On the other hand, in order to meet the priority sector targets, credit appraisal standards were lowered. During this period, the deposit and lending rate structure became very complex. Low return on Government securities and priority sector loans meant that other sectors had to be charged high interest rates. Interest rates differed as per type, size and location of borrowers. Interest rates specified were cheaper for certain activities such as food procurement, oil companies and certain key units in the public sector. Various controls combined with the absence of adequate competition resulted in decline in productivity and efficiency of the banking system and seriously eroded its profitability. Banks' capital position deteriorated and they were saddled with large non-performing assets.

3.126 In the mid-1980s, some efforts were made to liberalise and improve the profitability, health and soundness of the banking sector, which by then had transformed from a largely private owned system to the one dominated by the public sector. However, these were small steps considering the kind and extent of controls/regulations that came to prevail. Major reforms occurred in the next phase following structural reforms initiated by the Government in the early 1990s.

\section{Phase Of Financial Sector Reforms -1991-92 ONWARDS}

3.127 The banking sector in this phase evolved to a significant extent in response to financial sector reforms initiated as a part of structural reforms encompassing trade, industry, investment and external sector, launched by the Central Government in the early 1990s in the backdrop of a serious balance of payments problem. In order to realise the full potential of reforms in the real economy, the need was felt for a vibrant and competitive financial sector, particularly, banking sector. A high-powered Committee on the Financial System (CFS) was constituted by the Government of India in August 1991 to examine all aspects relating to the structure, organisation, functions and procedures of the financial system (Chairman: Shri M. Narasimham). The Committee, which submitted its report in November 1991, made wide-ranging recommendations, which formed the basis of financial sector reforms relating to banks, development financial institutions (DFIs) and the capital market in the years to come. The Committee underscored the commendable progress made by the banking sector in extending its geographical spread and its functions/operations and thereby promoting financial intermediation and growth in the economy. However, at the same time, the Committee noted with concern the poor health of the banking sector. The Committee cautioned that unless the deterioration in the financial health of the system was treated quickly, it could further erode the real value of and return on the savings entrusted to it and even have an adverse impact on depositor's and investor's confidence. Accordingly, financial sector 
reforms were initiated as part of overall structural reforms to impart efficiency and dynamism to the financial sector. The country's approach to reform in the banking and financial sector was guided by 'Pancha Sutra' or five principles: (i) cautious and sequencing of reform measures; (ii) introduction of norms that were mainly reinforcing; (iii) introduction of complementary reforms across sectors (monetary, fiscal, external and financial sectors); (iv) development of financial institutions; and (v) development and integration of financial markets. The evolution of the banking sector in this phase could be further divided into two sub-phases, i.e., from 199192 to $1997-98$ and $1997-98$ onwards.

\section{First Phase of Reforms: 1991-92 to 1997-98}

Financial Health and Soundness

3.128 A major issue faced by the banking sector in the early 1990s was its fragile health, low profitability and weak capital base. A related issue was also to assess the true health of the banking sector as the health code system being followed then was based on subjective considerations and lacked consistency. In order to address these issues, several mutually reinforcing measures were initiated. With a view to improving the health of the banking sector, internationally accepted prudential norms relating to income recognition, asset classification and provisioning, and capital adequacy were introduced in April 1992 in a phased manner. Banks were advised that they should not charge and take to income account, interest on any non-performing asset. For this purpose, nonperforming assets were clearly defined based on objective criteria. As compared with the then existing system of eight health codes, banks were required to classify their advances into four broad groups, viz., (i) standard assets, (ii) sub-standard assets, (iii) doubtful assets, and (iv) loss assets.

3.129 In the old eight category health code system, four categories were deemed as non-performing assets, viz., debts recalled, suit filed accounts, decreed debts, and debts classified as bad and doubtful and banks could not recognise interest income on these categories. However, there was no clear definition of problem credits and in actual practice banks could recognise interest income on all non-performing assets. The revised norms revealed a true position of banks' health. Aggregate domestic non-performing advances of all public sector banks, which constituted 14.5 per cent of total outstanding advances at end-March 1992 based on the old health code system, worked out to 23.2 per cent as on March 31, 1993 based on the revised classification. This implied that about one-fourth of banks' advances were locked in unproductive assets. This not only adversely affected banks' profitability but also prevented recycling of funds, thereby constraining the growth of their balance sheets.

3.130 Banks were also required to make provisioning to the extent of 10 per cent on sub-standard assets and 20 per cent to 50 per cent on secured portion of advances classified as 'doubtful', depending on the period for which the assets had remained doubtful. On unsecured portion of 'doubtful' assets and on 'loss' assets, 100 per cent provisioning was required to be made. Banks, however, were asked to continue to follow the health code system of classification of assets as a management information tool.

3.131 In order to strengthen the capital base of banks, capital to risk-weighted assets ratio (CRAR) system was also introduced for banks (including foreign banks) in India in a phased manner. Indian banks having branches abroad were required to achieve a capital adequacy norm of 8 per cent as early as possible and in any case by March 31, 1994. Foreign banks operating in India were to achieve this norm of 8 per cent by March 31, 1993. Other banks were required to achieve a capital adequacy norm of 4 per cent by March 31, 1993 and the 8 per cent norm by March 31, 1996.

3.132 The tentative provisioning required by banks was estimated at around Rs.10,000 crore by the Reserve Bank. Further, banks also required additional resources to meet the capital adequacy norms. The total resources required by the banks were close to Rs. 14,000 crore. Of this, the banks were able to provide about Rs.4,000 crore from their own surplus generation over a two-year period and about Rs.10,000 crore were required by the system as additional resources.

3.135 By end-March 1998, nine PSBs raised capital (including premium) aggregating Rs.6,015 crore from the market, including proceeds from the GDR issue of SBI aggregating Rs.1,270 crore raised during 1996-97. Besides, some banks also raised subordinated debt for inclusion in their Tier II capital. Raising of capital by banks led to diversification of ownership of PSBs, which made a significant qualitative difference to their functioning due to induction of private shareholding and attendant issues of shareholder's value and representation of private shareholders on boards (see also Chapter V).

3.136 In order to contain fresh NPAs from arising on account of adverse selection, banks were put on guard against the defaulters to other lending institutions. For this purpose, the Reserve Bank put in place a scheme on sharing credit data in April 1994. Apart from containing the fresh NPAs from arising, the issue was also to recover the NPAs which had already accumulated. In this context, commercial banks were advised to make the increasing use of Lok Adalats (people's court), which were conferred a judicial status and emerged as a convenient and low cost method of settlement of dispute between banks and small borrowers. Further, 'The Recovery of Debts Due to Banks and Financial Institutions Act' was enacted in 1993, which provided for the establishment of tribunals for expeditious adjudication and recovery of such debts. Following the enactment of 
the Act, 29 Debt Recovery Tribunals (DRTs) and 5 Debt Recovery Appellate Tribunals (DRATs) were established at a number of places in the country.

3.137 The various measures initiated had a favourable impact on the quality of banks' balance-sheets. In a short span, banks were able to bring down their non-performing assets significantly. Gross NPAs of public sector banks as percentage of gross advances, which were 23.2 per cent at end-March 1993, declined to 16.0 per cent by end-March 1998. Despite increased provisioning, overall profitability of the banking sector, in general, and public sector banks, in particular, improved as detailed in the subsequent section. The soundness of the banking sector also improved significantly. Of the 75 banks, 58 banks could achieve the stipulated CRAR of eight per cent by end-March 2006. Eight nationalised banks, six old private sector banks and three foreign banks could not attain the prescribed capital to risk weighted assets ratio of eight per cent by end-March 1996. They, therefore, were given one year extension to reach the prescribed ratio, subject to cer tain restrictions such as modest growth in risk-weighted assets and containment of capital expenditure and branch expansion, among others. At end-March 1998, out of the 27 PSBs, 26 banks attained the stipulated 8 per cent capital adequacy requirement. All banks, other than five banks (one public sector bank and four old private sector banks) were able to achieve the stipulated CRAR of eight per cent (Table 3.34).

\section{Removal of External Constraints on Banks}

3.138 One of the major factors that affected banks' profitability was high pre-emptions in the form of cash reserve ratio (CRR) and statutory liquidity ratio (SLR), which had reached at the historically high level of 63.5 per cent in the early 1990s. Besides, the administered structure of interest rates did not allow banks to charge the interest rates depending on the credit worthiness of the borrower and, thus, impinged on the allocative efficiency of resources. A phased reduction in the SLR and the CRR was undertaken beginning January 1993 and April 1993, respectively. The SLR was progressively brought down from the peak rate of 38.5 per cent in February 1992 to the then statutory minimum of 25.0 per cent by October 1997. There was a sharp reduction in the Central Government's fiscal deficit in the initial years of reforms. Accordingly, there was less of a need to use the banking sector as a captive source of funds. Interest rates on Government securities were also made more or less market determined. The CRR of scheduled commercial banks (SCBs), which was 15 per cent of net demand and time liabilities (NDTL) between July 1, 1989 and October 8, 1992, was brought down in phases to 9.5 per cent by November 22, 1997. Between November 1995 and January 1997, the CRR was reduced by as much as 5 percentage points. The incremental CRR of 10 per cent was also withdrawn.

3.139 The reduction in statutory pre-emptions not only removed the external constraints on banks having a bearing on their profitability, but also augmented the lendable resources of banks. Further, with the more normal liquidity conditions in the money market, there was further significant enhancement in the proportion of bank funds that was made available for financing growth and employment in the private sector. However, despite augmentation of lendable resources of banks, credit growth slowed down from 1996-97 both on account of demand and supply side factors. In view of application of prudential norms, banks became wary of enlarging their loan portfolio. The relatively high level of NPAs, in particular, had a severe impact on weak banks. Banks' capacity to extend credit was also impaired due to little headroom available in the capital adequacy ratio ( 8.7 per cent at end-March 1996). At individual bank level, some banks, as indicated earlier, were not able to meet the capital adequacy requirements at end-March 1998. The demand for funds by the corporate sector also slowed down. In the wake of increased competition in the product market, the corporate sector shifted its focus from expanding capacity to restructuring. Increased competition also forced the corporates to restructure their balance sheets, whereby they increased their reliance on retained earnings and reduced their borrowings. Rise in real interest rates caused by downward stickiness of nominal interest rates coupled with falling inflation rate also contributed to slackness in credit expansion (Mohan, 2005). Hence, despite lowering of statutory pre-emption in the form of CRR and SLR, banks continued to invest in government securities, far in excess of the requirements. Banks' investment in SLR securities at end-March 1996 was 36.9 per cent of net demand and time liabilities as against the statutory requirement of 31.5 per cent (see also Chapter VI).

3.140 Banks were also provided with freedom to fix their own deposit and lending rates. The structure of interest rates, which had become extremely complex, was first rationalised and then deregulated, barring a few rates both on the deposits and lending sides. The structure of interest rates on domestic term deposits, except for saving bank accounts, was made more flexible beginning October 1, 1995 (Box III.2). Prescriptions of interest rates on all term deposits, including conditions of premature withdrawal, and offering of the unifor $\mathrm{m}$ rate irrespective of size of deposits, were dispensed with. Banks were allowed to determine their own deposit rates, depending on commercial judgment, subject to the approval of their boards. Banks were also given the freedom to decide the rates on various nonresident deposits, subject to the ceiling prescribed by the Reser ve Bank. Interest rate ceilings prescribed for foreign currency denominated deposits and rupee deposits from non-resident Indians (NRIs) were continued as part of managing external debt flows, especially short-term flows.

3.141 Lending rates were rationalised from six to four categories in 1992-93 and further to three categories in 
1993-94. The process of rationalising the interest rate structure received a major impetus with the abolition of the minimum lending rate (MLR) for credit limits of over Rs.2 lakh, effective October 18, 1994 (Box III.2). The only lending rates that continued to be regulated were those pertaining to exports, small loans of up to Rs.2 lakh, and the differential rate of interest (DRI) scheme. Banks were required to announce a prime lending rate (PLR) for advances for over Rs. 2 lakh uniformly applicable at all the branches taking into account the cost of funds and transaction cost with the approval of their boards. Interest rates were deregulated to a significant degree not only to aid movement of monetary policy, but also because administered interest rate regime proved to be inefficient and costly, without necessarily ensuring the flow of credit to the needy. While deregulating interest rates, care was taken to ensure that banks did not have incentives, which tempted them to lend at high rates of interest assuming higher risks, i.e., the problem of adverse selection. A major safeguard in this regard was the prescription of provisioning and capital adequacy norms which compelled banks not to accept risk beyond a point.

3.142 Deregulation of interest rates implied that banks were able to fix the interest rates on deposits and loans, depending on the overall liquidity conditions and their risk perceptions (for lending rates). Banks, over the years, developed a set of criteria for determining the rate charged on individual borrowers. The deregulation of interest rates led to innovations of various types, including fixed, floating and partly fixed and partly floating interest rates, among others.

3.143 Lending interest rates of scheduled commercial banks had reached a peak of 20 per cent in October 1991. However, with abundant liquidity, resulting from large capital flows, interest rates after deregulation showed a distinct downward decline. By October 1997-98, lending interest rates declined to 14 per cent. Deposit interest rate also softened significantly from 13 per cent per annum (with maturity over 3 years and up to 5 years) in 1991-92 to 11.5-12.0 per cent (Table 3.35).

3.144 Reduction in NPAs together with reduction in CRR/SLR and deregulation of interest rates had a significant positive impact on the profitability of the banking sector. With the application of objective prudential norms, 14 banks (12 public sector banks) had reported net losses for the year ended March 1993. In 1996-97, the number of loss making SCBs declined to eight (of which 3 were public sector banks). Although in the next year, the number of loss making banks increased to 11, the number of loss making PSBs declined further to two. On the whole, the banking sector had turned around by 1994-95 as the financial results of 27 public sector banks during 1994-95 indicated a net profit of Rs.1,116 crore in contrast to a net loss of Rs.4,349 crore in 1993-94. The performance of nationalised banks was particularly significant as they registered a net profit of Rs. 270 crore during 1994-95 as compared with a net loss of Rs.4,705 crore in 1993-94. As a result, the profitability

\section{Box III.2}

\section{Deregulation of Interest Rates}

\section{A. Deposit Interest Rates}

October, 1989 Interest rates were rationalised on domestic short term deposits by merging two categories 46 days to 90 days and 90 days to one year. Interest rate on both these were made payable at a uniform rate, effective October 11, 1989. A similar simplification for NRE deposit rate was introduced effective April 16,1990 .

April 1992 The ceilings on deposit rates were simplified by replacing the existing maturity-wise ceiling prescriptions by a single ceiling rate of 13 per cent on all deposits above 46 days.

April 1993 A new Foreign Currency Non-Resident Deposits (Banks) [FCNR(B)] Scheme was introduced, under which the exchange risk was to be borne by the banks and interest rates prescribed by the Reserve Bank. The earlier scheme Foreign Currency NonResident Accounts, FCNR (A) was phased out by August 1994.

October 1995 To give flexibility to banks, deposits of maturity of over two years exempted from stipulation of ceilings.

April 1996 Interest rates on NRE term deposits of over 2 years were freed effective April 4, 1996. July 1996 Banks were given freedom to fix deposit rates for term deposits above one year maturity. For better short term management of funds, the minimum period of term deposit was brought down from 46 days to 30 days. For the maturity bucket of 30 days to 1 year, the banks could fix interest rates subject to a ceiling stipulated by the Reserve Bank.

April 1997 the ceiling interest rate on domestic term deposits of maturity of 30 days and up to 1 year was linked to Bank Rate. The interest rates on term deposits under NRE accounts of over 1 year were freed.

September 1997 Banks made free to fix their own interest rates on NRE term deposits of 6 months and over.

October 1997 Deposit rates, other than those on savings deposits and FCNR (B), were fully deregulated.

April 1998 Banks were given freedom to offer differential rate of interest for bulk deposits above Rs. 15 lakh and over and to set their own penal rates of interest on premature withdrawal of domestic term deposits and NRE deposits. Minimum period of maturity of term deposits reduced from 30 days to 15 days.

April 2001 Minimum maturity period of 15 days reduced to 7 days for wholesale deposits of Rs.15 lakh and 
above.

July 2003 Interest rate ceilings on NRE deposits were linked to LIBOR / SWAP rates.

November 2004 Minimum maturity period of 15 days reduced to 7 days for all deposits.

\section{B. Lending Interest Rates}

October 1988 The existing fixed rate stipulations were converted into minimum (floors) rates giving banks the option of raising the rates.

September 1990 Sector-specific and programme specific prescriptions were discontinued, barring a few areas like agriculture, small industries, differential rate of interest (DRI) scheme and export credit.

April 1992 the interest rates for advances of SCBs (except DRI advances and export credit) was rationalised by bringing the six slabs of advances to four slabs according to size of credit.

April 1993 Lending rates were further rationalised as the number of slabs were brought down from four categories to three categories by merging the first two slabs.

October 1994 Lending interest rates of scheduled commercial banks for credit limits of over Rs.2 lakh were deregulated effective October 18, 1994.

October 1995 Banks were given freedom to decide interest rate of advances against term deposits of Rs.2 lakh and above for both domestic and NRE deposits and to fix their own interest rates. The interest rate structure on post shipment credit in foreign currency (PSCFC) was rationalised.

February 1997 Banks allowed prescribing separate PLRs and spreads separately for loan and cash credit components of loans.

April 1998 Banks were allowed to charge interest rate on loans against fixed deposits equal to or less than their Prime Lending Rate (PLR). April 1999 Banks were provided freedom to operate tenor linked PLR.

April 2003 With a view to ensuring transparency in banks' lending rates as also for reducing the complexity involved in pricing of loans, a scheme of benchmark PLRs(BPLRs) was introduced. Concurrently the tenor linked PLR system was discontinued.of the banking sector (scheduled commercial banks), measured by return on assets, which had declined from 0.4 per cent in 1991-92 to

(-)1.1 per cent in 1992-93, improved to 0.8 per cent by 1997-98 (Table 3.36) (see Chapter IX for details).

3.145 Though the medium-term policy objective was to gradually reduce the CRR to the then statutory minimum of 3 per cent, the CRR has been gradually raised since September 2004 from 4.50 per cent to 9 per cent in view of prevailing monetary conditions. Similarly, the policy objective was to reduce the SLR below 25 per cent for which enabling legal provisions were also made. However, in view of prevailing monetary conditions, it has not been possible to reduce the SLR either. In the wake of inflation and tighter monetary policy, interest rates have also hardened. Banks were, therefore, urged to review their business strategies so that they would be in a position to combine longer-term viable financing with profitability in operations, recognising the reality of business cycles and counter-cyclical monetary policy responses.

Creating a Competitive Environment

3.146 The Indian banking sector over the years had become less competitive as no new bank was allowed to be set up in the private sector after nationalisation of 14 banks in 1969. Although a large number of players existed, there was no threat of entry of new players. The lack of threat of entry of new players led to inefficiency in the banking sector. Some other restrictions such as regulation of interest rates and the system of financing working capital requirements also had an adverse impact on the competitive environment. Banks were also constrained in their operations due to restrictions on opening or closing of branches on the basis of their commercial judgment. One of the major objectives of reforms was to bring in greater efficiency by permitting entry of private sector banks, liberalise licensing of more branches of foreign banks and the entry of new foreign banks and increased operational flexibility to banks. Keeping these in view, several measures were initiated to infuse competition in the banking sector.

3.147 First, the Reserve Bank allowed entry of new banks in the private sector. In January 1993, norms for the entry of new private sector banks were announced. Second, in the context of the steps towards deregulation and the changed banking scenario in the country, it was decided in May 1992 to give greater freedom to banks in the matter of opening of branches. While banks could not close down branches in rural areas, in order to enable them to rationalise their branch network in rural/semi-urban areas, they were allowed to rationalise their existing branch network by relocating branches within the same block and service area of the branch, shift their branches in urban/metropolitan/port town centres within the same locality/municipal ward, opening of specialised branches, spinning-off of business, setting up of controlling offices/administrative units and opening of extension counters. It was decided in December 1994 that banks need not obtain the Reserve Bank's prior permission for installation of automated teller machines (ATMs) at licensed branches and extension counters. Banks, however, were required to report such installation, if any, to the Reserve Bank. Banks were also given the freedom to install ATMs at other places, in which case they should obtain a licence from the concerned regional office of the Reserve Bank before operationalisation of off-site ATMs. Third, a commitment was made 
in the Uruguay Round to allow 12 licences a year for new entrants and existing banks. However, India adopted a more liberal policy in permitting branches of foreign banks in India. Fourth, the administered interest rate structure reduced the scope of price competition among banks and marginalised their incentive to efficiently allocate resources, as alluded to before. Deregulation of interest rates was, thus, a major element in the process of infusing competition as detailed earlier. Fifth, consistent with the policy of liberalisation, it was decided to allow full operational freedom to banks in assessing the working capital requirements of borrowers. Accordingly, all instructions relating to maximum permissible bank finance (MPBF) were withdrawn in April 1997. Banks were given the total freedom to decide on the methodology of assessing working capital requirements. It was for corporates to convince banks about their working capital needs. Corporates could choose to go through a single bank, consortium arrangement or take a syndicate route. Sixth, all restrictions relating to project loans by commercial banks were withdrawn. Traditionally, project finance was a domain of term-lending institutions.

3.148 Although the competitive conditions were created, the competition within the banking sector during this phase did not penetrate enough. Following liberalisation of entry of new private sector banks, 10 new banks were set up in the private sector by 1998. Besides, 22 foreign banks were also set up. The number of foreign bank branches increased from 140 at end-March 1993 to 186 at end-March 1998. The share of new private sector banks in total assets of scheduled commercial banks increased to 3.2 per cent by end-March 1998. The share of foreign banks at 8.2 per cent at end-March 1998 was the same as at end-March 1993. That the impact on competition remained muted was also evident from the limited number of mergers (four). Normally when competition intensifies, it inevitably leads to increased mergers and acquisitions activity (see Chapter VIII for details). The lack of enough competition was also reflected in the net interest margins (NIM) of banks, which increased during this phase from 2.51 per cent in 1992-93 to 2.95 per cent in 1997-98 (refer Chapter IX for details). This was despite the fact that banks during this phase were in a disadvantageous position as interest rates during this phase declined significantly as detailed earlier. It may be noted that the effect of reduction in interest rates on lending is mostly instantaneous, while on deposit rates, it comes into operation after existing deposits mature.

3.151 Another significant institutional development was in the field of customer service. The Reserve Bank, as the regulator of the banking sector, was actively engaged, from the very beginning, in the review, examination and evaluation of customer service in the banks. The Reserve Bank's enduring and abiding concern for the quality of services extended to the bank customers was reflected in its regulatory initiatives taken from time to time. It was expected that competition in the banking sector through deregulation and entry of new private sector banks would lead to provision of high-quality customer service to meet the long-standing aspirations of the bank customers. However, there was an increasing realisation, both in India and several other countries that the forces of competition alone did not ensure the fair treatment of the customer or adequate quality of customer service, at a justifiable price, determined in a transparent manner. This, therefore, necessitated interventions from the regulators to institutionalise a mechanism for securing better customer service for the public at large (Leeladhar, 2007). Accordingly, for expeditious and inexpensive resolution of customer complaints against deficiency in banking services, the Reserve Bank announced in June 1995, the Banking Ombudsman Scheme, 1995 under the provisions of the Banking Regulation Act, 1949. The Scheme covered all scheduled commercial banks having business in India, except RRBs and scheduled primary co-operative banks. Any person whose grievance pertaining to any of the matters specified in the scheme was not resolved to his satisfaction by the bank within a period of two months could approach the Banking Ombudsman within a period of one year.

3.152 The Banking Ombudsman Scheme was revised during the years 2002 and 2006. The Banking Ombudsman Scheme (BOS) 2006 covers all Commercial Banks, Regional Rural Banks and Scheduled Primary Co-operative Banks under its scope. Banking Ombudsman have been authorised to look into complaints concerning deficiency in banking service and sanction of loans and advances, in so far as they relate to nonobservance of the Bank directives on interest rates etc. BOS 2006 included new areas like credit card issues, failure in providing the promised facilities, non-adherence to fair practices code and levying of excessive charges without prior notice etc. In order to facilitate easy complaint submission, the application format though prescribed is not made mandatory for filing a complaint and complaints can be filed online as well as by sending an email or in hard copy. As per the BOS 2006, in order to have more control over the functioning of the Scheme, the entire expenditure involved in running the Scheme is now borne by the Reserve Bank and not shared by participating banks as was prevalent till then and the Offices of the Banking Ombudsman are now fully manned by the Bank's staff as against staff from SLBC convenor banks earlier. Any bank, against whom and Award was passed can with the approval of its Chief Executive, file an appeal with Appellate Authority who is the Deputy Governor, Reserve Bank of India in charge of the Banking Ombudsman Scheme. In terms of an amendment made in May 2007 complainants can also appeal against the decisions of Banking Ombudsman in respect of matters falling within the grounds of complaint specified under the Scheme.

Improving the Rural Credit Delivery System 
3.153 Notwithstanding the impressive geographical spread, functional reach, improved credit flow to agriculture and consequent decline in the influence of informal sources of credit, rural financial institutions were characterised by several weaknesses, viz., decline in productivity and efficiency; erosion of repayment ethics and profitability. On the eve of the 1991 reforms, the rural credit delivery system was again found to be in a poor shape ${ }^{33}$. While the question of imparting viability to the total credit structure had engaged the attention of the authorities/ committees, a viable structure did not evolve. It was, thus, imperative to devise a rural credit delivery system which did not require large subvention. In this context, it was felt that there was a need for better alignment of interest rates and mix of target and non-target lending. There were also various other areas where the rural credit delivery system was quite clearly unsatisfactory and it was felt imperative that early measures needed to be taken to bring about an enduring improvement in the credit delivery system.

3.154 The Committee on Financial System, 1991 had recommended that there was a need for re-examination of the continued relevance of directed credit programme and that it should be phased out. It also recommended that the priority sector be redefined to comprise small and marginal farmers, tiny sector of industry, small business and transport operators, village and cottage industries, rural artisans and other weaker sections and the credit target for this redefined priority sector should be fixed at 10 per cent of aggregate credit. For ensuring the flow of credit to sectors excluded from the redefined priority sector, the Committee on Financial System recommended the introduction of a refinance facility from the Reserve Bank.

3.155 A detailed assessment by the Reserve Bank indicated that the redefined priority sector would account for significantly larger than 10 per cent of total credit and as such acceptance of the Committee's recommendation would put a severe squeeze on the sectors within the redefined priority sector. It was also felt that there was little merit in a drastic reduction in the target for the priority sector and then meeting the requirements of these sectors through refinance from the Reserve Bank as this would result in increasing the amount of created money, thereby fuelling inflationary pressures. From a pragmatic viewpoint, it was essential to ensure that any changes in the policy on priority sector credit did not result in a disruption in the flow of credit for productive purposes. It was felt that while there was a case of reviewing the coverage and targets for the priority sector lending, the experience of a number of countries was that some direction of credit was necessary (RBI, 1992). However, after the micro-regulation of credit delivery was given up and banks were given freedom in matters relating to credit, there were apprehensions on two counts, viz., and the discipline of priority sector lending and flow of credit to the needy and deserving, on a timely basis. The activities eligible for priority sector lending, therefore, were enlarged, interest rates deregulated and alternative avenues of investment were permitted, thereby making the priority sector lending far more flexible than before.

3.156 Many banks, both in the public and private sectors, were not able to meet the priority sector targets. Therefore, those public and private sector banks which had shortfalls in lending to the priority sector or to agriculture were required to contribute specified allocations to the Rural Infrastructure Development Fund (RIDF). The first RIDF was established with NABARD in 1995-96 to provide loans to the State Governments for financing rural infrastructure projects. The RIDF became the main instrument to channelise bank funds for financing rural infrastructure. By 1998, four tranches of RIDF were set with a total corpus of Rs.10,000 crore. Total amount disbursed from all the four RIDF combined together aggregated Rs.9,095 crore.

3.159 These measures had a desired impact on the financial performance of RRBs. The number of profit making RRBs increased sharply to 109 during 1997-98 from 34 in the previous year. RRBs, as a group, also earned net profits of Rs.43 crore during 1997-98 as against net losses of Rs. 589 crore incurred during the previous year.

3.160 Apart from strengthening commercial banks and RRBs, several measures were initiated for ameliorating the problems in the flow of agricultural credit. First, the coverage of rural credit was extended to include facilities such as storage as well as credit through NBFCs. Second, procedural and transactional bottlenecks were sought to be removed, reducing margins, redefining overdues to coincide with crop-cycles, new debt restructuring policies, one-time settlement and relief measures for farmers indebted to non-institutional lenders. Third, the Kisan Card Scheme was improved and widened in its coverage, while some banks popularised General Credit Cards (GCCs) which was in the nature of clean overdraft for multipurpose use, including consumption. Fourth, public and private sector banks were encouraged to enhance credit delivery while strengthening disincentives for shortfall in priority sector lending. Fifth, the banks were urged to price the credit to farmers based on actual assessment of individual risk rather than on a flat rate, depending on category of borrower or end-use while ensuring that interest-rates charged were justifiable as well as reasonable. Some other measures were also initiated, which covered delegation of more powers to branch managers, simplification of applications, opening more SSI specialised branches, enhancement in the limit for composite loans and strengthening of the recovery mechanism. In brief, the thrust was on improving credit delivery in a regime of reasonable prices within the existing legal and institutional constraints.

3.161 Notwithstanding various measures, credit flow to agriculture decelerated to 17.3 per cent during the 6year period from 1992-93 to 1997-98 as compared with 18.1 per cent during 1980s. Credit to agriculture as percentage to total credit, credit intensity and priority sector advances to agriculture as percentage of gross non- 
food bank credit also declined between end-March 1993 and end-March 1998 (Table 3.37) (see Chapter VI for details).

3.162 To sum up, the main issues faced at the beginning of this sub-phase (1991-92 to 1997-98) were the poor financial performance, low asset quality, weak capital position of banks and the absence of adequate competition. Several measures, therefore, were initiated by the Government, the Reserve Bank and the banks themselves to improve their profitability, financial health and capital position. Major measures initiated included the introduction of objective prudential norms, reduction in statutory pre-emptions and operational flexibility and functional autonomy to public sector banks. In view of various risks faced by the banking sector in a liberalised environment, a special emphasis was also placed on strengthening the supervisory processes. Various measures initiated had a profound impact. A significant improvement was observed in the financial performance, asset quality and capital position by the end of this sub-phase. The improvement in the financial performance was indeed remarkable as the banks were subjected to the objective accounting norms. This, among others, was on account of improvement in asset quality and widening of net interest margins. One of the objectives of reforms was to create competitive conditions. Although several measures were initiated to create competitive environment, competition remained muted. A major contribution of various reform measures in this phase was that it led to a change in the behaviour of banks in that they began to focus increasingly on improving their financial health and profitability. Despite significant improvement, however, there were still some concerns at the end of this sub-phase. First, the NPA level of public sector banks was still very high by international standards. Second, some banks were not able to achieve the stipulated capital adequacy ratio even after two years of the stipulated time period. Third, although the banking sector, on the whole, turned around during 1994-95 and made profits, some banks (including two public sector banks) continued to incur losses at the end of this phase. Fourth, competition did not penetrate enough and banks continued to enjoy high net interest margins. Notwithstanding the improved credit flow to agriculture before the onset of reforms, rural financial institutions such as RRBs suffered from serious weaknesses. Efforts, therefore, were made to restructure them, which had a desired impact on their financial health. In this phase, however, credit to the agricultural sector decelerated.

\section{Second Phase of Reforms: 1998-99 and Onwards}

Strengthening of Prudential Norms and NPA Management

3.163 Although the prudential norms relating to income regulation, asset classification and provisioning introduced early in the reforms phase was a major step towards objective assessment of the profitability and financial health of the banking system, in several respects these norms fell short of international best practices. The need, therefore, was felt to strengthen them further and bring them on par with the international best practices. The East Asian crisis in June 1997 also suggested the risks a weak banking system could pose to the real economy. The framework for further strengthening the banking sector was provided by the Committee on Banking Sector Reforms - CBSR (Chairman: Shri M. Narasimham), which submitted its report in April 1998. However, while strengthening the prudential norms, it was also necessary to ensure that some risk aversion by banks, which had surfaced after application of prudential norms, did not aggravate.

3.164 In October 1998, the stipulated minimum capital to risk-weighted assets ratio (CRAR) of scheduled commercial banks was raised by one percentage point to 9 per cent from the year ended March 31, 2000. Riskweights were also prescribed for Government and other approved securities, investments in securities outside the SLR and State Government guaranteed securities issued by defaulting entities.The experience of banks facing asset-liability mismatches in the South East Asian countries underlined the need for putting in place necessary asset liability management (ALM) practices. Banks were, therefore, subjected to asset liability management (ALM) framework. The increased complexity in banking operations, and the need to prevent financial crises of the type witnessed in East Asia, also necessitated continuous efforts towards strengthening the soundness of financial entities, and in particular, upgradation of risk management practices and procedures. The ALM framework was, therefore, complemented with guidelines on risk management.

3.165 Income recognition, asset classification and provisioning norms were also tightened. Banks were required to make a general provision on standard assets of a minimum of 0.25 per cent for the year ended March 31 , 2000, which was subsequently raised steadily to one per cent. This measure was envisaged to mitigate the procyclical behaviour of banks. The concept of 'past due' in the identification of non-performing assets (NPAs) was dispensed with effect from March 2001. According to the revised norms, an asset was to be treated as doubtful, if it remained in sub-standard category for 18 months instead of 24 months, by March 31, 2001. Asset classification norms were tightened further in May 2002, when banks were advised that from the year ended March 2005, an asset would be classified as doubtful if it remained in the sub-standard category for 12 months as against the earlier norm of 18 months.

3.166 Income recognition norms were tightened further from March 2004, whereby an asset was classified as 
NPA if it remained unpaid for a period of 90 days instead of six months earlier. In June 2004, the Reserve Bank advised banks further to adopt graded higher provisioning in respect of (a) secured portion of NPAs included in 'doubtful' for more than three years category; and (b) NPAs which remained in 'doubtful' category for more than three years as on March 31, 2004. Provisioning was also increased ranging from 60 per cent to 100 per cent over a period of three years in a phased manner from the year ended March 31, 2005. Asset classification and provisioning requirements in respect of State Government guaranteed exposures were delinked from the invocation of State Government guarantee.

3.167 The Basel Committee on Banking Supervision (BCBS) of BIS had issued the 'Amendment to the Capital Accord to Incorporate Market Risks' containing comprehensive guidelines to provide explicit capital charge for market risks. Pending implementation of BCBS' norms on capital charge for market risk, banks were advised in January 2002 to build up investment fluctuation reserve (IFR) which should be at least 5 per cent of their investments in 'held for trading' (HFT) and 'available for sale' (AFS) categories within five years so that they were in a better position to meet the market risk. Subsequently, in June 2004, banks were required to maintain capital charge for market risks on the lines of Basel norms in a phased manner over a two-year period.

3.170 Various measures initiated to recover past due of banks had a favourable impact as banks recovered as much as Rs.25,520 crore between 2003-04 and 2006-07 locked in NPAs using various mechanisms (Table 3.38). Although the asset quality had been improving after introduction of prudential norms, it showed a distinct improvement in this phase as both gross and net NPLs declined sharply to around global levels (Table 3.39).

3.171 As the asset quality began to improve, credit growth, which had decelerated significantly between 199697 and 2003-04 partly on account of risk aversion, began to pick-up from 2004-05. Credit growth, which was initially concentrated in retail segment, soon turned broad-based encompassing agriculture, industry and small scale sector. Credit growth accelerated to over 30 per cent in 2004-05 and remained more or less at that level in the following two years. Banks deposit growth rate, however, was not able to keep pace with the rapid credit growth. Banks, which had made large investments in SLR securities in excess of SLR requirements on account of risk aversion, first restricted incremental investments in Government securities (2004-05) and then even liquidated investments in SLR securities (2005-06). In 2006-07, although banks made incremental investments in Government securities, SLR portfolio as percentage of NDTL continued to decline. As a result, investment in SLR securities, which had reached an all-time high level of 41.5 at end-March 2003, declined gradually to 28.0 per cent by end-March 2007.

3.172 An important feature of the rapid credit growth was the sharp increase in bank credit to the household sector. As a result, the share of retail credit in total bank credit increased from 10 per cent at end-March 1996 to 25 per cent at end-March 2007. Within household credit, housing loans constituted about a little over one-half of total loans. In view of sharp increase in growth of advances to the real estate sector, banks were advised to put in place a proper risk management system to contain the risks involved. In view of rapid credit expansion, the Reserve Bank in April 2006 indicated that growth of non-food bank credit, including investments in bonds/debentures/ shares of public sector undertakings and private corporate sector and commercial paper, would be calibrated to decelerate to around 20 per cent during 2006-07 from a growth of above 30 per cent. The general provisioning requirement on standard advances in specific sectors, i.e., personal loans, loans and advances qualifying as capital market exposures, residential housing loans beyond Rs.20 lakh and commercial real estate loans was increased from 0.40 per cent to one per cent in April 2006 and further to two per cent on January $31,2007$.

3.173 The Reserve Bank used prudential measures in combination with increase in the policy rates. Keeping in view the persistent growth of credit to the retail sector and also keeping in view the general inflationary conditions, the repo rate was increased by 175 basis points in stages to 7.75 per cent by March 31, 2007 from 6.0 per cent in March 2004. ${ }^{34}$ The CRR, which was reduced to 4.5 per cent in March 2004, was gradually raised to 7.5 per cent effective March 31, 2007. $\frac{35}{5}$ These measures had a desired impact and the credit growth moderated to 21.6 per cent in 2007-08 (see also Chapter VI). A sharp increase in credit between 2004-05 and 2006-07 resulted in sharp increase in the risk weighted assets. Despite this increase, however, banks were able to maintain their CRAR significantly above the stipulated norm (Table 3.40). This, to a large extent was facilitated by improved profitability as it allowed banks to increase their retained earnings (see Chapter $\mathrm{V}$ for details).

\section{Competition Intensified}

3.174 Although the competitive conditions were created in the early 1990s, their impact remained muted, as alluded to before. However, competition began to intensify in the early 2000s, which, was reflected in the increased mergers and acquisitions activity. In this phase, two large development finance institutions (DFIs) merged/converted into banks. After concessional sources of funding in the form of Long-Term Operation (LTO) Fund of the Reserve Bank and Government guaranteed bonds were withdrawn in the early 1990s, DFIs found it difficult to sustain their operations. In January 2001, the Reserve Bank permitted the reverse merger of ICICI 
with its commercial bank subsidiary. ICICI Ltd. became the first DFI to convert itself into bank. The ICICI was the second largest DFI, after Industrial Development Bank of India, and its reverse merger led to a sharp increase in the market share of new private sector banks in total assets of the banking sector. On October 1, 2004, Industrial Development Bank of India, another large DFI, was converted into a banking company. In April 2005, it merged its banking subsidiary (IDBI Bank Ltd.) with itself. In all, during this phase, four new private sector banks and one new public sector bank came into existence (including conversion of two major DFIs, viz., ICICI and IDBI into banks). Besides, 16 foreign banks were also set up. However, despite emergence of new domestic and foreign banks, the number of banks gradually declined beginning from 100 at end-March 2000 to 82 by end-March 2007, reflecting the increased competitive pressures as detailed in Chapter VIII. The number of branches set up by foreign banks increased from 181 in June 1997 to 273 by March 2007. Increased competition was also reflected in the sharp increase in the sub-BPLR lending by banks. With a view to addressing the downward stickiness of PLRs and the wide disparity in charging interest to different category of borrowers, a scheme of benchmark PLRs (BPLRs) was introduced by the Reserve Bank in 2003-04 for ensuring transparency in banks' lending rates as also for reducing the complexity involved in pricing of loans. However, owing to increased competition, many banks introduced sub-BPLR lending and the spreads between the minimum and maximum lending rates increased significantly. The sub-BPLR lending enabled the corporates to raise funds at competitive rates from banks. The share of sub-BPLR lending in total lending increased gradually from 43 per cent in 2003-04 to 79 per cent by end-March 2007. As a result, net interest margins came under pressure, especially during the last few years as detailed in Chapter IX.

3.175 During this phase, some more measures were undertaken to strengthen the competitive environment. With liberalisation of the FDI regime, FDI in the banking sector was brought under the automatic route. With a view to further liberalising foreign investment in the banking sector, the Government announced (vide GOI press note of March 5, 2004) an increase in the FDI limit in private sector banks from 49 per cent to 74 per cent under the automatic route, including investment by FIIs, subject to guidelines issued by the Reserve Bank from time to time. However, the FII investment limit could not exceed 49 per cent within the aggregate foreign investment ceiling of 74 per cent of the paid up capital and at all times, at least 26 per cent of the paid-up capital, was required to be held by residents. In several old and new private sector banks, non-residents now hold majority equity (Table III.41).

3.176 In consultation with the Government of India, the Reserve Bank released the roadmap for the presence of foreign banks in India on February 28, 2005. In terms of the two stages envisaged in the roadmap, the roadmap in the second stage is due for review in April 2009. A policy for merger/amalgamation of private sector banks was also formulated covering details of the process of merger proposal, determination of swap ratios, disclosures, and norms for buying/selling of shares by the promoters before and during the process of merger (see Chapter VIII for details).

3.177 The branch authorisation policy was also liberalised and rationalised in September 2005 in order to give reasonable freedom to banks and rationalise the policy for opening of new branches in India. The system of granting authorisation for opening individual branches from time to time was replaced by a system of giving aggregated approvals, on an annual basis, through a consultative and interactive process. The revised branch authorisation policy granted reasonable flexibility and freedom to banks in matters relating to shifting, conversion of branches and upgradation of extension counters (see Chapter X for details).

Diversification and Emergence of Universal Banks/ Financial Conglomerates $\underline{\underline{36}}$

3.178 Increased competitive pressures within the banking sector and also from non-banks and the capital market, made banks to seek new sources of income by offering a variety of services either within the organisation or by setting up subsidiaries. Prior to initiation of reforms, banks were mostly engaged in traditional non-fund based business, viz., opening letters of credit, acceptances, issuing guarantees, remittance business and foreign exchange business such as offering forward contracts to exporters/ importers. Although banks had started diversifying in the mid-1980s after the necessary enabling provisions were incorporated in the Banking Regulation Act, 1949, diversification gained momentum in the late 1990s. Apart from offering merchant banking activities and services connected with the activity of primary issue, banks started rendering project appraisal, capital structure, fund raising and loan syndication services under one roof. Banks also started rendering advisory services to corporates, including on mergers and acquisitions, and custodial and depository services for both domestic and foreign customers. Banks were also allowed to undertake insurance business (without underwriting). Diversification of business led to gradual increase in non-interest income, the share of which in total income increased significantly between 1999-2000 and 2004-05. The decline in the share in the subsequent years was mainly on account of decline in the share of trading income/losses (Table 3.42).

3.179 Banks also became active in setting up subsidiaries to undertake various non-traditional activities such as insurance. The number of subsidiaries set up by banks increased from 37 at end-March 1998 to 131 by endMarch 2008. A few non-banking financial intermediaries had also become large enough to cause systemic impact. The number of cross-border financial conglomerates operating in and out of India also emerged. From a 
regulatory perspective, the above developments led to an appreciation of the limitations of the segmented approach to supervision in addressing the potential risks arising out of operations of bank-led groups and financial conglomerates. The Reserve Bank, therefore, mandated consolidated supervision for all groups where the controlling entity was a bank. All banks that came under the purview of consolidated supervision of the Reserve Bank were advised to prepare and disclose consolidated financial statements (CFS) from the financial year ended March 2003, in addition to their single financial statements. For the purpose of application of prudential norms on a group-wide basis, the prudential norms/limits such as capital to risk-weighted asset ratio (CRAR), single/group borrower exposure limits, liquidity ratios, mismatches limits and capital market exposure limits were prescribed for compliance by the consolidated bank.

3.180 Keeping in view the systemic risks posed by the emergence of financial conglomerates, a monitoring mechanism was also put in place in consultation with other regulators, viz., Securities and Exchange Board of India and Insurance Regulatory Authority. A nodal cell was established at the Reserve Bank for smooth implementation of the monitoring mechanism (see Chapter $\mathrm{X}$ for details).

Ownership and Governance

3.181 Ownership and governance of banks assume special significance as they accept and deploy large amount of uncollateralised public funds and leverage such funds through credit creation. Banks also participate in the payment mechanism. However, the two major concerns arose in the Indian context regarding corporate governance in banks. These were concentration of ownership and the quality of management that controlled the bank. Regulation of private banks was crucial in view of the fact that the owner shareholders of the banks had only a minor stake and considering the leveraging capacity of banks, it put them in control of a very large volume of public funds of which their own stake was miniscule (Mohan, 2004b). This required a set of norms that adequately addressed the issues that arose from the concentrated shareholding in banks controlling huge public funds in the form of concentration of ownership and the associated moral hazard problem and linkages of owners with businesses. A diversification of ownership was considered desirable, as also ensuring 'fit and proper' status of such owners and directors.

3.182 Legal prescriptions relating to ownership and governance are laid down in the Banking Regulation Act, 1949. These were supplemented by regulatory prescriptions issued from time to time. According to one such stipulation, for private sector banks, all shareholders with holdings of 5 per cent and above were required to meet the 'fit and proper' tests of competence, reputation, track record, integrity, satisfactory outcome of financial vetting, source of funds and so on. Where the applicant was a corporate, 'fit and proper' test was to include good corporate governance, financial strength and integrity in addition to the assessment of individuals and other entities associated with the body corporate, as indicated above. The allotment transfer of shares to the extent of five per cent and above of the paid-up capital of a private sector bank to an entity / group required the prior acknowledgement of the Reserve Bank. However, detailed guideline were issued in this regard on February 3, 2004. The objective was to ensure that shareholders with aggregate holdings above the specified thresholds met the fitness and propriety tests before grant of acknowledgement of transfer of shares. In June 2004, the Reserve Bank also directed the banks in the private sector that they should undertake a process of due diligence to determine the suitability of the person for appointment/continuing to hold appointment as a director on the Board, based upon qualification, expertise, track record, integrity and other 'fit and proper' criteria.

3.183 Further, the Reserve Bank after a detailed consultative process released a comprehensive policy framework of ownership and governance in private sector banks in February 2005. The broad principles underlying the framework were to ensure that (i) ultimate ownership and control was well diversified; (ii) important shareholders were 'fit and proper'; (iii) directors and CEO were 'fit and proper' and observed sound corporate governance principles; (iv) private sector banks maintained minimum net worth of Rs.300 crore for optimal operations and for systemic stability; and (v) policy and processes were transparent and fair.

3.184 In order to attain a well-diversified ownership structure, it was prescribed that no single entity or a group of related entities should have shareholding or control, directly or indirectly, in excess of 10 per cent of the paidup capital of a private sector bank. Any bank having shareholding in excess of 5 per cent in any other bank in India was required to indicate a time bound plan for reduction of such holding to the permissible limit of 5 per cent. The parent of any foreign bank having presence in India having shareholding directly or indirectly through any other entity in the banking group in excess of 5 per cent in any other bank in India was similarly required to indicate a time bound plan for reduction of such holding to 5 per cent. In the case of restructuring of problem/weak banks or in the interest of consolidation in the banking sector, the Reserve Bank could permit a higher level of shareholding, including by a bank. A minimum of Rs.300 crore of net worth was perceived as being desirable on grounds of optimal operations and systemic stability. Banks with net worth lower than Rs.300 crore were advised to increase it to this level within a reasonable period. The commitments made as part of the licensing process were also to be taken into account as also to be continuing compliance with 'fit and proper' and sound governance.

3.185 Keeping in view the importance of corporate governance even in public sector banks, the Government of 
India at the Reserve Bank's initiative, carried out amendments to the Banking Companies (Acquisition and Transfer of Undertakings) Act, 1970/ 1980 and the State Bank of India (Subsidiary Banks) Act, 1959 to include new sections providing for applicability of 'fit and proper' criteria for elected directors on the boards of public sector banks. Necessary guidelines were issued to nationalised banks in November 2007.

\section{Credit Delivery - SMEs}

3.186 Unlike large industries, which have access to various domestic and international sources of finance, small and medium enterprises (SMEs) are dependent largely on bank finance. Consequent upon the deregulation of interest rates, there was an expectation that credit flow to the needy will increase. However, credit to the SME sector decelerated in the 1990s (8.1 per cent as compared with 20.7 per cent in the 1980s) and the first four years of the current decade. Realising the critical role of small industries in the economy, the Reserve Bank initiated several measures with a view to increasing the flow of credit to Small Scale Industry (SSI) units. These included refining the definition of small scale and tiny enterprises; broadening the scope for indirect finance to these industries; making investments in several avenues such as securitised assets, lines of credit, bills-discounting and leasing and hire purchase eligible for priority sector advances. Besides, in pursuance of the recommendations made by several working groups and high powered committees appointed by the Central Government and the Reserve Bank, a set of comprehensive guidelines to be followed for advances to all categories of borrowers in the SSI sector was evolved.

3.187 To give the benefit of the soft interest rate policy of the Reserve Bank to SSI, banks were advised to set the interest rate on advances to SSI units keeping in view general downward movement in interest rates. Further, as per the announcement made in the Union Budget 2003-04, the Indian Banks' Association advised the banks to adopt the interest rate band of two per cent above and below its BPLR for secured advances. To mitigate the problem of delayed payment, banks were further advised to fix sub-limits within the overall working capital limits to the large borrowers specifically for meeting the payment obligation in respect of purchases from SSI. To make available timely credit to the sector, a timeframe was fixed for disposal of loan applications. In the Mid-term Review of Monetary and Credit Policy for 2003-04, banks were allowed to increase the loan limit from Rs.15 lakh to Rs.25 lakh (with the approval of their boards) for dispensation of collateral requirement, on the basis of good track record and the financial position of the SSI units. Moreover, all new loans granted by banks to NBFCs for the purpose of on-lending to the SSI were also allowed to be reckoned as priority sector lending.

3.188 Several other measures were also initiated to increase the flow of credit to the SSI sector. These included identification of new clusters and adopting cluster-based approach for financing the small and medium enterprises (SME) sector; sponsoring specific projects as well as widely publicising the successful working models of NGOs; sanctioning higher working capital limits to SSIs in the North Eastern region for maintaining higher levels of inventor y; and exploring new instruments for promoting rural industry. Interest rates on deposits placed by foreign banks with SIDBI in lieu of shortfall in their priority sector lending obligations were restructured and the tenor of deposits was increased from one year to three years with effect from financial year 2005-06.

3.189 Various measures had a positive impact on the credit flow to the SME sector, which accelerated from 2004-05. The average growth rate of lending to the SME sector during last three years (2004-05 to 2006-07) accelerated to 37.3 per cent from 8.1 per cent in the 1990s. Notwithstanding this acceleration, the share of the SSI sector in total bank credit declined to 16.9 per cent at end-March 2007 (from 27.9 per cent at end-March 1991) and in total credit to industry to 38.7 per cent (from 54.3 per cent). Credit intensity of the SSI sector in 2006-07 was less than that in 1990-91, which itself was quite low due to decelerated growth in that year (see Chapter VI for details).

Improving Credit Delivery - Rural Sector

3.190 Several concerns were expressed in relation to rural credit from time to time in terms of inadequacy, constraints on timely availability, high cost, neglect of small and marginal farmers, low credit-deposit ratios in several States and continued presence of informal markets. It was held that while the commercial banks were more focused in improving efficiency and profitability, they tended to give comparatively less priority to rural credit. In spite of a series of actions, there was some element of dissatisfaction that overall situation with regard to rural credit did not improve to the desired level. In fact, credit growth to agriculture during the 1990s slowed down to almost one-half as compared with the 1980s. The decline in the share of agriculture in capital formation relative to its share in real GDP in the late 1990s and the early 2000 was a cause of concern exacerbated by the decline in credit-deposit ratio of the rural branches of SCBs. Additionally, several SCBs reported shortfalls in lending to the priority sector, including agriculture. The Government and the Reserve Bank, therefore, took several measures to increase the flow of credit to agriculture.

3.191 The Government announced a package of measures on June 18, 2004 aimed at doubling agricultural credit in three years with a credit growth of 30 per cent for 2004-05. Pursuant to the announcement, necessary 
measures were initiated by the Reserve Bank and the IBA in respect of commercial banks, and by NABARD in respect of cooperative banks and the RRBs. These measures included (i) debt restructuring and provision of fresh loans to farmers affected by natural calamities; (ii) one-time settlement for small and marginal farmers; (iii) fresh finance for farmers whose earlier debts were settled through compromise or write-offs; and (iv) relief measures for farmers indebted to non-institutional lenders. The actual disbursement of credit to agriculture by banks exceeded the targets during all the three years up to 2006-07. Carrying forward this measure, the Union Finance Minister fixed a target of Rs.2,25,000 crore for disbursements by banks for 2007-08 and a target of Rs.2,80,000 crore was fixed for 2008-09. Several other measures were also initiated by the Reserve Bank to simplify the procedures and process for obtaining agricultural loans to assist distressed farmers and persons affected by natural calamities.

3.192 The Reserve Bank initiated several other measures to increase the flow of credit to the agriculture sector. These included (i) treating loans to storage units designed to store agricultural products, irrespective of location, as indirect credit to agriculture; (ii) treating investment by banks in securitised assets representing direct (indirect) lending to agriculture as direct (indirect) lending to agriculture; and (iii) waiver of margin/security requirement for agricultural loans up to Rs.50,000 and in case of agri-business and agri-clinics for loans up to Rs.5 lakh. In addition, the Reserve Bank also aligned repayment dates with harvesting of crops by treating loans granted for short duration crops as an NPA, if the instalment of the principal or interest thereon remained unpaid for two crop seasons beyond the due date. Loans granted for long duration crops were treated as NPAs only if the instalment of the principal or interest thereon remained unpaid for one crop season beyond the due date.

3.193 In order to further promote the outreach of the banking sector, banks have been permitted to use the services of non-Governmental organisations/self-help groups (NGOs)/(SHGs), micro finance institutions (MFIs) and other civil society organisations (CSOs) as intermediaries in providing financial and banking services through the use of business facilitator and business correspondent models. These intermediaries can take banking to the doorstep of the people. This step will facilitate banks to offer competition to the informal sector, which had been thriving due its accessibility, flexibility and ease in conducting transactions.

3.194 In view of decline in credit to agriculture, the need was felt to reposition the RRBs as an effective instrument for the rural credit delivery system, improve their operational viability and take advantage of the economies of scale (by reducing transaction cost). Accordingly, the route of merger/amalgamation of RRBs was suggested by an Advisory Committee (Chairman: Shri V.S. Vyas) after taking into account the views of various stakeholders. The merged entities, according to the Group, would have a larger area of operation and the merger process would help in strengthening some of the weak RRBs. A two-phase restructuring was suggested (i) merger between RRBs of the same sponsor bank in the same State; and (ii) merger of RRBs sponsored by different banks in the same State.

3.197 A number of policy initiatives were also undertaken to facilitate the diversification of RRBs business operation into new areas. To give new directions to RRBs for becoming an important arm for financial inclusion in rural areas, the Government reviewed the performance of RRBs on January 25, 2007. Accordingly, RRBs were encouraged to enhance their deposit base and increase the credit-deposit ratio from the level of 56 per cent by exploiting the emerging potential under both priority and non-priority sector. For strengthening the RRBs and making them financially stronger and competitive, the Government further considered recapitalisation of RRBs having negative net worth. The Government of India issued a notification on May 17, 2007 specifying 'regional rural bank' as 'bank' for the purpose of the SARFAESI Act, 2002. With a view to improving their performance, RRBs were allowed to undertake, with prior permission of the Reserve Bank, insurance business as corporate agents without risk participation, subject to fulfilling certain terms and conditions such as positive net worth, compliance with prudential norms, NPAs not exceeding 10 per cent, continuous profits in the last 3 years and no accumulated losses.

3.198 Rural co-operatives also displayed several weaknesses over the years, which inhibited their ability to effectively compete with commercial banks. These weaknesses included low resource base, poor business diversification and recoveries, huge accumulated losses, lack of professionalism and skilled staff, weak MIS, poor internal check and control systems. As a result, the share of the co-operative banks in agricultural credit declined over the years. The financial health of co-operative banks also deteriorated. The Government, therefore, after extensively consulting the State Governments announced a 'revival package' together with reforms to be brought about for short-term credit co-operatives with a view to making them truly democratic, autonomous, vibrant, member driven, professionally managed and financially strong.

3.201 The operations of RRBs improved significantly as a result of several measures that were initiated by the Government and the Reserve Bank. The financial performance of RRBs improved further with the number of loss making RRBs declining further to 15 during 2006-07 from 22 during 2004-05. Net NPLs of RRBs declined from 5.2 per cent at end-March 2005 to 3.4 per cent at end-March 2007. Credit growth of RRBs accelerated to 22.9, on an average, during the three-year period (2004-05 to 2006-07) from 17.8 per cent on an average during the preceding three years (2001-02 to 2003-04) and 17.7 per cent during the previous 10 years (1994-95 to 
2003-04).

Financial Inclusion

3.202 Bank nationalisation in India marked a paradigm shift in the focus of banking as it was intended to shift the focus from class banking to mass banking. The rationale for creating regional rural banks was also to take the banking services to poor people. The banking industry witnessed tremendous growth in volume and complexity over the years. Despite making significant improvements in all the areas relating to financial viability, profitability and competitiveness since the early 1990s, there were concerns that banks had not been able to include vast segment of the population, especially the underprivileged sections of the society, into the fold of basic banking services. That is, notwithstanding the outreach of the banking sector, the formal credit system was not able to adequately penetrate into the informal financial markets. Internationally also, efforts were being made to study the causes of financial exclusion in order to design strategies to ensure financial inclusion of the poor and disadvantaged.

3.203 The Reserve Bank was also concerned with regard to the banking practices that tended to exclude vast sections of population. It was, therefore, felt necessary to bring them within the fold of the formal banking sector so that at least the basic banking services were made available equitably to all sections of the society, not only to promote financial inclusion $\frac{37}{}$ of the excluded class of people but also to expand their business. It was in this context that in the Annual Policy Statement for the year 2005-06, the Reserve Bank stated that there were legitimate concerns with regard to the banking practices that tended to exclude rather than attract vast sections of population, in particular pensioners, self-employed and those employed in the unorganised sector. The Policy noted that while commercial considerations were no doubt important, banks were bestowed with several privileges, and consequently, they needed to be obliged to provide banking services to all segments of the population, on an equitable basis. Against this background, the Policy stated that the Reserve Bank would implement policies to encourage the banks which provided extensive services while disincentivising those which were not responsive to the banking needs of the community, including the underprivileged. Furthermore, the nature, scope and cost of services rendered by the banks were also to be monitored to assess whether there was any denial, implicit or explicit, of the basic banking services to the common person. Banks were, therefore, urged in the Policy Statement to review their existing practices to align them with the objective of financial inclusion.

3.204 It was recognised that in many banks, the requirement of minimum balance and charges levied, although accompanied by a number of free facilities, deterred a sizeable section of population from opening/maintaining bank accounts. The Reserve Bank, therefore, advised the banks in November 2005 to make available a basic banking 'no-frills' account either with 'nil' or very low minimum balances as well as charges that would make such accounts accessible to vast sections of population. This was aimed at achieving the objective of greater financial inclusion. The nature and number of transactions in such accounts could be restricted, but made known to the customer in advance in a transparent manner. Banks were also advised to give wide publicity to the facility of such a 'no-frills' account, including on their websites, indicating the facilities and charges in a transparent manner. Within two years of the introduction of the scheme, there was a significant progress. By end-December 2007, about 12.6 million 'no frills' accounts were opened by scheduled commercial banks in India (see Chapter VII for details).

Urban Co-operative Banks

3.205 The initiation of financial sector reforms had posed new challenges for the urban co-operative banks. First, the reform measures had substantially increased competition in the banking sector. Second, the structural changes in the Indian banking sector beginning the early 1990s increased the interdependence among financial institutions, especially through inter-institutional exposures and payments and settlement channels. Deterioration in the financial position of the co-operative banks could therefore get easily transmitted to the other segments of the financial sector, which may lead to a systemic problem. Accordingly, after the introduction of a fairly deregulated regime set in 1993 and the more deregulated scenario of the commercial banking sector, the Reserve Bank felt that it should take stock of the performance of the urban co-operative banking sector. Lower entry level norms in the mid-1990s had contributed to a significant weakness in the UCBs. As the UCBs were part of the payment system, their weakness could have serious repercussions for the rest of the financial system. It was, therefore, necessary to put in place a regulatory framework so as to make the cooperative sector competitive and resilient. It was also felt necessary to find solutions to tackle problems created by dual control of UCBs by the Reserve Bank under Banking Regulation Act, and State Governments under the respective State Co-operative Societies Acts.

3.206 The urban co-operative banking sector, however, received a major setback in 2001 when a large multistate bank, faced a 'run' on its branches, following rumours of its large exposure to a leading broker who had suffered huge losses in the share market. The failure of this co-operative bank had large scale ramifications for the UCBs sector. Even from the point of view of the banking sector, it posed a systemic risk as the bank also held about Rs. 800 crore of inter-bank deposits from a large number of UCBs in the State and from other States. 
In order to protect the interests of the general public and also that of the other co-operative banks, the Reserve Bank had issued directions to the bank restricting certain operations (acceptance of fresh deposits, restricting payments to any single depositor to Rs.1000 and ban on fresh lending) and requisitioned the Central Registrar of Co-operative Societies, New Delhi to supersede the board of directors and appoint an administrator. An order of moratorium was also enforced on the bank by the Central Government for a short period. The bank was subsequently placed under a scheme of reconstruction with the approval of the Reserve Bank. The next episode of the failure of UCB was in the State of Andhra Pradesh in 2002, when one of the largest banks in the state faced a run, following a newspaper report regarding an inquiry instituted into the affairs of the bank by the State Registrar of Co-operative Societies.

3.207 Failures of co-operative banks brought to the fore the need to have appropriate supervision over the cooperative banking system. A supervisory reporting system was introduced for the scheduled UCBs in April 2001 as a first step towards setting up of OSS for all UCBs. With a view to strengthening the supervisory mechanism, the off-site surveillance system (OSS) was extended to cover all non-scheduled UCBs having deposit size of Rs.50 crore and above. Capital adequacy norms were introduced in a phased manner beginning March 2002.

3.208 The deposit growth in the UCBs sector decelerated sharply to 15.1 per cent during the year ended March 2002 as against the growth of about 25.7 per cent in the previous three years. The decline in public confidence in the UCB sector deepened in the aftermath of the crisis involving a few large UCBs in Gujarat and Andhra Pradesh and concomitantly, the position of UCBs generally deteriorated. The number of UCBs, which had steadily increased till 2003, declined in 2004 (to 1926 from 1941 in 2003). Their share in total deposits of the banking sector (scheduled commercial banks, RRBs and UCBs) also declined significantly (to 5.8 per cent in 2004 from 6.3 per cent in 2003). As on June 30, 2004, 732 out of 1919 UCBs were categor ised in Grade III or IV, signifying weakness and sickness. Recognising the systemic risks and keeping in view the needs of UCBs' clientele, the Reserve Bank in the Annual Policy Statement for the Year 2004-05, announced a decision to stop granting fresh licenses for formation of new UCBs. It was, therefore, decided by the Reserve Bank not to grant any fresh branch license. It was made clear that this was necessitated pending a comprehensive review of the legislative and regulatory framework governing the sector. It was against this background that a decision was taken to draft a vision document for the sector to outline a framework that would facilitate the strengthening of the sector and enable it to play the assigned role of providing credit to the economically weaker sections. The Reserve Bank reviewed the entire gamut of legislative, regulatory and supervisory framework for these banks and brought out a draft 'Vision Document for UCBs' in March 2005.

3.209 The 'Vision Document' provided a fresh framework with practical and implementable arrangements to rejuvenate the urban co-operative banks. As proposed in the 'Vision Document', the Reserve Bank approached the State Governments/ Central Government (for multi state UCBs) for signing MOUs to ensure greater coordination between the two agencies responsible for regulation and supervision of UCBs. As part of the MOU, it was decided to set up State level Task Force for Cooperative Urban Banks (TAFCUBs) comprising representatives of the Reser ve Bank, State Government and federation/association of UCBs. The TAFCUBs were entrusted to identify the potentially viable and non viable UCBs in the respective States and provide a revival path for the former and a non-disruptive exit route for the latter set of banks. The exit route could include merger/ amalgamation with stronger banks, conversion into societies or ultimately as a last resort, through liquidation. Since June 2005, MOUs were signed with 19 State Gover nments and Central Government (in respect of multi-State UCBs), which comprise 1,597 UCBs, i.e., 90 per cent of the banks representing 95 per cent of deposits of the sector. Taking into account the comfort of coordinated supervision and regulation in the States that signed MOU with the Reserve Bank, certain business opportunities were extended to the eligible banks in such States as also to the multi-State UCBs. Requests from eligible banks in such States for additional business opportunities like setting up currency chests, authorised dealer license for forex business, selling mutual funds and opening of new ATMs, among others, are also considered by the Reserve Bank. It was announced in the Annual Policy Statement for the year 2007-08 that financially sound banks in such States would also be permitted to open new branches, a facility which was not available to UCBs from 2004. Also, the consolidation of UCBs through the process of merger of weak entities with stronger ones was set in motion providing transparent and objective guidelines for granting 'no objection' to merger proposals. A total of 53 mergers were affected through the issue of statutory orders by the Central Registrar of Co-operative Societies/ Registrar of Co-operative Societies (CRCS/RCS) concerned.

3.210 Various measures initiated by the Reserve Bank helped in restoring the confidence in the UCB sector, which was reflected in the various business and financial health parameters of the UCB sector. Deposits and advances of UCBs, which had registered a negative growth of 4.7 per cent and 1.6 per cent, respectively, during the year ended March 2005, turned positive from the year ended March 2006 (Table 3.43).

3.211 Their asset quality also improved. Gross NPAs, which were 23.2 per cent of total advances at end-March 2005, declined to 17.0 per cent by end-March 2007. The share of UCBs in grade III and IV, implying weakness and sickness, in total UCBs also declined (Table 3.44). 


\section{Customer Service and Financial Literacy}

3.212 The Reserve Bank initiated various measures to improve the customer service from time to time. A major policy initiated in this regard was the setting up of Banking Ombudsman at various offices of the Reserve Bank. Recognising the institutional gap in measuring the performance of the banks against codes and standards based on established best practices, the Reserve Bank in its Annual Policy Statement for 2005-06 announced the setting up of the Banking Codes and Standards Board of India (BCSBI). It was set up as an autonomous and independent body adopting the stance of a self-regulatory organisation. The BCSBI provided for voluntary registration of banks with the Board as its members and committing to provide customer services as per the agreed standards and codes. The Board, in turn, monitored and assessed the compliance with codes and standards which the banks agreed to. The Board released in July 2006, a Code of Bank's Commitment to Customers to provide a framework for a minimum standard of banking services. The Code was not only a commitment of the banks to their customers but, in a sense, was also a charter of rights of the common man visà-vis his bank. As at end-October 2007, out of 74 scheduled commercial banks registered with the BCSBI indicating their intention to become members, 70 banks, accounting for 98 per cent of the total domestic assets of the Indian banking system, enrolled as its members.

3.215 In the context of increasing focus on financial inclusion, and the past episodes of financial distress observed in cer tain segments of the farming community, the need was also felt to provide a mechanism for improving the financial literacy and level of financial education among the consumers of banking services. Some urgency was lent to this issue in India by the rapid growth in consumer loans and housing loans. In such a situation, credit counselling, by providing sound advice to arrest the deterioration of incomes and to restructure their debt, could offer a meaningful solution for the borrowers and could enable them to gradually overcome their debt burden and improve their money management skills. The banks had a role to play in the area of providing financial education to their customers, as timely counselling of the borrowers could have positive impact on the asset quality of the banks. A few banks have since set up credit counselling centres. Various initiatives by the Reserve Bank led to qualitative improvement in customer service.

Technology

3.216 Technology was identified by banks as a crucial element in their strategy to improve productivity and render efficient customer service. The computerisation of bank operations in a big way began in the early 1990s following the agreement between the Indian Banks' Association (IBA) and employees. Over the years, the use of technology increased significantly. Two areas in which the use of technology was clearly visible was computerisation of branches and installation of ATMs. Most of the banking business of public sector banks gradually came to be captured through computerisation. However, most of these efforts were on a standalone basis. It, therefore, was felt that the pace of internal computerisation of branches of banks and their interconnectivity, providing for core banking systems (CBS), needed to be expedited. All CBS branches are interconnected with each other, which enables a customer to operate his accounts, and avail banking services from any branch of the bank on CBS networking, regardless of where he maintains his account. This improves the quality and efficiency of services. In 2002, therefore, banks were urged to bestow special attention to the computerisation and networking of branches on a time-bound basis. By end-March 2007, about 86 per cent branches were fully computerised, of which a little more than half the branches were under core banking solutions (Table 3.45).

3.217 The use of ATMs also increased significantly in recent years. The number of on-site ATMs almost doubled between end-March 2005 and end-March 2007. The number of off-site ATMs also increased. The ratio of ATMs to branches also improved significantly in recent years (Table 3.46).

3.218 Recognising the importance of the payment systems, a number of initiatives were undertaken for bringing about efficiency in the payment and settlement systems. To reduce risk in the electronic payment systems, the implementation of real time gross settlement(RTGS) and national electronic fund transfer(NEFT) enabled receipt of funds on a real time/near to real time basis on a credit-push basis. The share of electronic transactions, both in terms of volume and value has increased significantly in recent years (Table 3.47). In India, the spread of the RTGS system was very rapid in comparison with other countries.

3.219 Technology helped the banks to innovate in terms of developing new products and services such as phone banking and internet banking. IT also helped in handling large transactional volumes and adapting according to the changing customer expectations, apart from providing almost real time information processing capabilities for both the banks and the customers. Technology ensured a rapid transformation of the banking sector by ushering in competition, productivity and efficiency of operations, and better asset/liability management, among others. Effective funds movements through the RTGS platform also greatly helped the cash management by banks.

3.220 Technology also posed some challenges. The possibility of making online transactions through internet made the banks susceptible to misuse of this facility. These issues were addressed by banks by putting in place appropriate safeguards and mechanisms to establish the identity of customers based on guidelines issued by the 
Reserve Bank. Similarly, the technology posed challenges in terms of the business continuity. Therefore, regular and periodic disaster recovery drills (DR) were performed by banks. In this regard, the common minimum requirements were indicated by the Reserve Bank for banks to follow, which were applicable for all new ITbased systems and delivery channels.

3.221 During the last 15 years of reforms, some momentous changes have taken place in the Indian banking sector (Box III.3).

3.222 To sum up, after nearly 10 years of the second phase of reforms, the complexion of the Indian banking sector changed quite significantly. The main issues faced in this sub-phase were to (i) strengthen the prudential norms in line with the international best practices and at the same time ensure that the risk aversion did not aggravate; (ii) increase the flow of credit to agriculture and SMEs; (iii) bring a large segment of excluded population within the fold of the banking sector; (iv) strengthen the corporate governance practices; (v) strengthen the urban cooperative banks and resolve the issue of dual control; and (vi) improve the customer service. On almost all the fronts, there was a significant improvement. Although efforts to strengthen the banking sector had begun in the early 1990s, norms introduced were not in line with the international best practices. Also, with the application of prudential norms, banks had developed risk aversion. Therefore, while strengthening prudential norms, institutional arrangements were put in place to enable banks to expeditiously recover their past dues. Various measures initiated had a positive impact as banks were able to recover large amounts locked up in NPLs. Banks, therefore, gradually shed their risk aversion and credit began to grow sharply beginning from 2004-05. Banks' NPLs level gradually declined to global level; their gross NPAs declined from 15.4 per cent at end-March 1997 to 2.5 per cent at end-March 2007. This was the most important achievement of this phase. The profitability of scheduled commercial banks as reflected in their average return on asset improved further, albeit marginally, from 0.8 per cent in 1997-98 to 0.9 per cent in 2006-07. This was significant because competition intensified during this phase as reflected in the acceleration of mergers and acquisitions (M\&As) activity and squeezing of net

Box III.3

\section{Major Banking Sector Reforms - 1991-92 onwards \\ Policy Reforms}

- Prudential norms relating to income recognition, asset classification, provisioning and capital adequacy were introduced in a phased manner in April 1992.

- Guidelines on entry of private sector banks were put in place in January 1993.

- The BFS instituted a computerised Off-site Monitoring and Surveillance (OSMOS) system for banks in November 1995 as a part of crisis management framework for 'early warning system' (EWS) and as a trigger for on-site inspections of vulnerable institutions.

- A phased reduction in the SLR was undertaken beginning January 1993. The SLR was progressively brought down from the peak rate of 38.5 per cent in February 1992 to the then statutory minimum of 25.0 per cent by October 1997.

- The CRR was progressively reduced effective April 1993 from the peak level of 15 per cent to 4.5 per cent by June 2003. The CRR was subsequently raised in stages to 9.0 per cent effective August 30, 2008.

- The Board for Financial Supervision (BFS) was set up in July 1994 within the Reserve Bank to attend exclusively to supervisory functions and provide effective supervision in an integrated manner over the banking system, financial institutions, non-banking financial companies and other para-banking financial institutions.

- Rationalisation of lending interest rates was undertaken begining April 1993, initially by simplifying the interest rate stipulations and the number of slabs and later by deregulation of interest rates. Deposit interest rates, other than those on savings deposits and $\mathrm{FCNR}(\mathrm{B})$ were fully deregulated (see Box III. 2 for details).

- The Banking Ombudsman Scheme was introduced in June 1995 under the provisions of the BR Act, 1949.

- The maximum permissible bank finance (MPBF) was phased out from April 1997.

- In order to strengthen the capital base of banks, the capital to risk-weighted assets ratio for banks was raised to 9 per cent from 8 per cent, from year ended March 31, 2000.

- With a view to liberalising foreign investment in the banking sector, the Government announced an increase in the FDI limit in private sector banks under the automatic route to 49 per cent in 2001 and further to 74 per cent in March 2004, including investment by FIIs, subject to guidelines issued by the Reserve Bank.

- The Banking Codes and Standards Board of India (BCSBI) was set up by the Reserve Bank as an autonomous and independent body adopting the stance of a self-regulatory organisation in order to provide for voluntary registration of banks committing to provide customer services as per the agreed standards and codes.

- A comprehensive policy framework for governance in private sector banks was put in place in February 2005 in order to ensure that (i) ultimate ownership and control was well diversified; (ii) important shareholders were 'fit and proper'; (iii) directors and CEO were 'fit and proper' and observed sound corporate governance principles; (iv) private sector banks maintained minimum capital for optimal operations and for systemic stability; and (v) policy and processes were transparent and fair. 
- The roadmap for the presence of foreign banks in India was drawn up in February 2005.

- A mechanism of State level Task Force for Co-operative Urban Banks (TAFCUBs) comprising representatives of the Reserve Bank, State Government and federation/ association of UCBs was instituted in March 2005 to overcome the problem of dual control over UCBs.

- A risk based supervision (RBS) approach that entails monitoring according to the risk profile of each institution was initiated on a pilot basis in April 2004.

- Banks were advised to introduce a facility of 'no frills' account with nil or low minimum balances in November 2005.

- In January 2006, banks were permitted to utilise the services of non-governmental organisations (NGOs/ SHGs), micro-finance institutions and other civil society organisations as intermediaries in providing financial and banking services through the use of business facilitator and business correspondent (BC) models.

\section{Legal Reforms}

- The Recovery of Debts Due to Banks and Financial Institutions Act was enacted in 1993, which provided for the establishment of tribunals for expeditious adjudication and recovery of non-performing loans. Following the enactment of the Act, debt recovery tribunals (DRTs) were established at a number of places.

- In order to allow public sector banks to approach the capital market directly to mobilise funds from the public, an Ordinance was promulgated in October 1993 to amend the State Bank of India Act, 1955 so as to enable the State Bank of India to enhance the scope of the provision for partial private shareholding.

- Amendments to the Banking Companies (Acquisition and Transfer of Undertakings) Act, 1970/80 were also carried out to allow nationalised banks to have access to the capital market, subject to the condition that the Government ownership would remain at least at 51 per cent of equity of nationalised bank.

- The Securitisation and Reconstruction of Financial Assets and Enforcement of Security Interest (SARFAESI) Act, 2002 was enacted in March, 2002.

- Section 42 of the RBI Act was amended in June 2006 to remove the ceiling (20 per cent) and floor ( 3 per cent) on the CRR.

- Section 24 of the BR Act was amended in January 2007 to remove the floor of 25 per cent on the SLR to be statutorily held by banks.

Interest margins. The improved profitability, despite increased competition, was, among others, on account of (a) sharp decline in NPLs; and (b) increased credit volumes. In order to improve their profitability in a competitive environment, banks also increasingly diversified their activities. This, in turn, led to emergence of bank-led groups/financial conglomerates. The capital adequacy ratio of banks also improved from 8.7 per cent at end-March 1997 to 12.9 per cent at end-March 2007. At individual bank level, the CRAR of most banks was over 10 per cent, i.e., higher than the stipulated target which itself was higher than the international norm. Thus, the impact of reforms initiated in the early 1990s became clearly visible in this phase as the Indian banking sector had become competitive, profitable and strong.

3.223 In this phase, two major concerns arose regarding corporate governance practices in banks in India. These were concentration of ownership and the quality of management that controlled the bank. Appropriate norms, therefore, were put in place to ensure diversification of ownership and those owners and directors satisfied the 'fit and proper' criteria.

3.224 Credit to the SME and agriculture sectors decelerated in the 1990s and early years of the current decade. Given the significance of both the sectors, concerted efforts were made by the Government and the Reserve Bank to increase the flow of credit to these sectors. As a result, the decelerating trend of lending to agriculture and SMEs by banks was reversed. Sharp increase in credit to agriculture led to sharp increase in credit intensity of agriculture. The restructuring of RRBs by merging them sponsor bank-wise at the state level made them larger and stronger to serve as a better instrument of rural credit delivery. Credit growth to SMEs also accelerated in recent years, although the share of credit to the SME sector in total bank credit and credit intensity of the SME sector in 2007 was significantly lower than that in 1991.

3.225 Notwithstanding the rapid progress made by the banking sector over the years, a large segment of population on low income continued to remain outside the banking system. Banks, therefore, were urged to open 'no frills' accounts with nil or minimum balances. This had a significant positive impact as banks brought a large number of financially excluded people (about 13 million) within their fold in a short span of two years. Another issue faced in this subphase was erosion of confidence in the UCB sector. The main challenge in respect of UCBs was, thus, to restore the confidence in the UCBs sector and resolve the problem of dual control. The mechanism of Task Force on Urban Co-operative Banks (TAFCUBs) comprising representative of the Reserve Bank, State Government and federation/association of UCBs was adopted to identify potentially viable and non-viable UCBs in the respective State to provide a revival path for the former and non-disruptive route for the latter set of UCBs. So far, MOUs constituting the TAFCUBs have been signed with the 19 State Governments. The confidence in the UCB sector was restored which was reflected in the positive growth of 
deposit rates in recent years, reversing the trend of negative growth in 2004-05. The overall quality of the UCB sector also improved, which was evident from the decline in the number of grade III and IV UCBs (signifying weakness/sickness) in total UCBs.

3.226 The use of technology increased significantly in this phase. A large number of branches of public sector banks (86 per cent of total branches) were computerised, of which nearly half were under core banking solutions. The number of ATMs installed also increased. This enabled banks to provide improved customer service. The use of electronic payment transactions also increased sharply. A specific mechanism was also put in place to benchmark the customer service against the international best codes and standards. On the whole, the banking sector by the end of this phase had undergone massive transformation from the one with low profitability, weak capital base, poor asset quality to profitable, strong capital position and high asset quality.

\section{Summing Up}

3.227 The Indian banking sector has been evolving continuously. The initial phase (up to 1947) was a difficult period for the banking sector. A large number of banks sprang up as there were no entry norms for banks. The Swadeshi Movement during this phase saw the establishment of many Indian banks, most of which continue to operate even now. In this phase, which was marked by the two World Wars and the Great Depression, many banks failed. Most of the small banks were local in character and had low capital base. As a result, they were not resilient enough. Apart from the global factors, one of the major reasons for failures of small banks was fraudulent manipulation by directors and managers and inter-connected lending. Also, several banks that failed had combined trading functions with banking functions. Partly, in order to address the problem of bank failure, the Reserve Bank was set up in 1935. In fact, central banks in several other countries, including the US, were also set up to address the problem of bank failure. However, the Reserve Bank had a limited control over banks and lack of an appropriate regulatory framework posed a problem of effective regulation of small banks. By the end of this phase, the country's financial requirements were still catered to, in a large measure, by the unorganised sector. The focus of the banking sector was on urban areas and the requirements of agriculture and the rural sector were neglected. Although the co-operative credit movement had a very encouraging beginning, it did not spread as expected despite Government patronage.

3.228 The period after independence could be categorised broadly in three phases: (i) 1947 to 1967; (ii) 1967 to 1991-92; and (iii) 1991-92 and beyond. The banking scenario that prevailed in the early independence phase faced three main issues. First, bank failures had raised the concerns regarding the soundness and stability of the banking system. Second, there was large concentration of resources from deposits mobilisation in a few hands of business families or groups. Banks raised funds and on-lent them largely to their controlling entities. Third, agriculture was neglected insofar as bank credit was concerned. In order to address the issue of bank failures, the Banking Companies Act (renamed as Banking Regulation Act in March 1966) was enacted in 1949 empowering the Reserve Bank to regulate and supervise the banking sector. Banks continued to fail even after the Independence and the enactment of the Banking Companies Act, although the number of banks that failed declined. It was, therefore, felt that it would be better to wind up insolvent banks. The Reserve Bank, therefore, was granted powers in the early 1960s for consolidation, compulsory amalgamation and liquidation of small banks. Although some banks had amalgamated before 1960s, the number of banks amalgamating rose sharply between 1960 and 1966. Several other small banks otherwise also ceased to function. The Reserve Bank was fairly successful in improving the safety and soundness of the banking sector as several weak banks (most of which were non-scheduled) were weeded out through amalgamations/liquidations. The deposit insurance was also introduced, which increased the trust of the depositors in the banking system and encouraged deposit mobilisation. In early years of banking in India there were thus several instances which suggest that the small and weak banks struggled to survive. Even in recent years, it is several small banks that have merged with the large banks. Another feature that emerges from the evolution of banking till the end of this phase was that despite the existence of small banks, a large segment of the population remained outside the banking system. In other words, the existence of small banks did not necessarily promote financial inclusion.

3.229 On the eve of independence, the banking system was concentrated primarily in the urban and metropolitan areas. Efforts, therefore, were made to spread banking to rural and unbanked areas, especially through the State Bank of India and through the branch licensing policy. The number of bank branches rose significantly between 1951 and 1967, as a result of which the average population per branch fell from 1,36,000 in 1951 to 65,000 in 1969. However, the pattern of bank branches in rural and urban areas remained broadly the same.

3.230 Although the Indian banking system had made considerable progress in the 1950s and the 1960s, the benefits of this did not percolate down to the general public in terms of access to credit. This was primarily due to the nexus between banks and industrial houses that cornered bulk of bank credit, leaving very little for agriculture and small industries. Efforts, therefore, were made to increase the flow of credit to agriculture. However, the share of agriculture in total bank credit remained broadly at the same level between 1951 and 1967. In this period, various objectives such as enhancing the deposit rates, while keeping the cost of credit for 
productive activities at a reasonably low level led to a complex structure of interest rates and other micro controls.

3.231 The second phase after independence (1967 to 1991-92) was characterised by several social controls over the banking sector. The major issue faced at the beginning of this phase was the strong nexus between banks and industry, as a result of which agriculture was ignored. The focus in this phase was, thus, to break the nexus and improve the flow of credit to agriculture. The main instruments used for this purpose were nationalisation of major banks in the country and priority sector lending. These initiatives had a positive impact in terms of spread of the bank-branch network across the country, which in turn, accelerated the process of resource mobilisation. As a result of rapid branch expansion witnessed from 1969, the average population per bank office, which was 65,000 at the time of nationalisation, declined to 14,000 by end-December 1990. Large branch expansion also resulted in increase in deposits and credit of the banking system, especially in rural areas. The share of credit to agriculture in total bank credit increased from 2.2 per cent in 1967 to 15.8 per cent in June 1989. However, these achievements extracted a price in terms of health of bankinginstitutions. Banks did not pay adequate attention to their profitability, asset quality and soundness. The increase in credit to the priority sector led to the reduction of credit to the other sectors. Attempts were, therefore, made to bring some financial discipline in respect of credit to the corporate sector. However, norms stipulated for the purpose were found to be too rigid. On the other hand, in order to meet the priority sector targets, credit appraisal standards were lowered. The high statutory preemptions eroded the profitability of the banking sector. Lack of enough competition resulted in decline in productivity and efficiency of the system. At the end of this phase, banks were saddled with large nonperforming assets. Banks' capital position turned weak and they lacked the profit motive. During this period, the deposit and lending rate structure became very complex. By the early 1980s, the banking sector had transformed from a largely private owned system to the one dominated by the public sector. In the mid-1980s, some efforts were made to liberalise and improve the profitability, health and soundness of the banking sector. This phase also saw some diversification in banking activities.

3.232 The most significant phase in the evolution of banking was the phase of financial sector reforms that began in 1991-92, which had two sub-phases (1991-92 to 1997-98; and 1998-99 and beyond). The main issues faced in the first sub-phase (1991-92 to 1997-98) was the weak health of the banking sector, low profitability, weak capital base and lack of adequate competition. The reforms in the initial phase, thus, focused on strengthening the commercial banking sector by applying prudential norms, providing operational flexibility and functional autonomy and strengthening the supervisory practices. To infuse competition in the banking sector, several measures were initiated such as allowing the entry of private banks into the system. A major achievement of this phase was significant improvement in the profitability of the banking sector. Some improvement was also observed in the asset quality, capital position and competitive conditions, although there was still a significant scope for further improvement. However, banks in this phase developed risk aversion as a result of which credit expansions slowed down in general and to the agriculture in particular.

\section{References}

[1]. As quoted by the Indian Central Banking Enquiry Committee (1931), Chapter II page 11.

[2]. Hundis are the oldest form of credit instruments that were used as early as the 12 century AD. Deposits were accepted by some indigenous banks under the 'khata putta' system. However, most indigenous banks like Multanis and Marwaris did not accept deposits as they relied on their own funds, see Bagchi(1987).

[3]. Northcote Cooke, 'Rise and Progress of Banking in India' (1863) quoted by Tandon (1988).

[4]. Reserve Bank of India (2006).

[5]. Indian Central Banking Enquiry Committee (1931)

[6]. Reserve Bank of India (History), Volume I, page 6.

[7]. RBI (1999), Madhav Rao Committee Report, Chapter II.

[8]. The name Imperial Bank of India was suggested by Lord John Maynard Keynes.

[9]. Reserve Bank of India (History) Vol.II, Pg 235

[10]. The Indian Central Banking Enquiry Committee (1931).

[11]. The Indian Central Banking Enquiry Committee (1931).

[12]. The Indian Central Banking Enquiry Committee (1931).

[13]. Till November 1951, when the Reserve Bank stopped the practice of buying such securities barring under exceptional circumstances.

[14]. "Central Banking in India, A Retrospect", Speech by Shri C.D Deshmukh for the Shri R.R.Kale Memorial Lecture at Gokhale Institute of Politics \& Economics, 1948.

[15]. Reporting banks included banks in categories A1, A2, B, C and D.

[16]. Handbook of Statistics on the Indian Economy, 2006-07.

[17]. The Act (No.23 of 1965) substituted the word "Regulation" for the word Companies; the Act was renamed as the Banking Regulation Act, 1949 effective March 1, 1966.

[18]. As referred to in the Reserve Bank(History) Volume II, page 465.

[19]. RBI History Vol. II pg 791.

[20]. RBI History, Volume II, Page 1.

[21]. Rural Banking Enquiry Committee (1950).

[22]. RBI History Vol. I.

[23]. RBI History Volume I, pg 238. 
[24]. RBI History Volume II, pg 338.

[25]. RBI History Vol. II pages 425 .

[26]. RBI (History) Volume II.

[27]. Page 38, Banking Commission, 1971

[28]. Tandon Committee (1975)

[29]. Method I: 25 per cent of the working capital gap, i.e., difference between current assets and current liabilities excluding bank finance to be funded from long terms resources. The minimum current ratio under this method was to be 1:1. Method II: 25 per cent of current assets to be funded from long term resources. The remaining 75 per cent of current assets less current liabilities to be funded by bank finance. The minimum current ratio under this method was stipulated at 1.33:1. Method III: 25 per cent of current assets less core current assets being funded from long term resources. The current ratio under this method would be greater than 1.33 .

[30]. A committee was set up for reviewing the system of Cash Credit (Chairman: Shri K.B. Chore),

[31]. Narasimham Committee Report, 1991.

[32]. Ibid.

[33]. R.V. Gupta Committee (1998).

[34]. The repo rate was subsequently raised in phases to 9.0 per cent effective July 29, 2008.

[35]. The CRR was subsequently raised in stages to 8.75 per cent effective July 19, 2008, (to be 9.0 per cent effective August 30, 2008).

[36]. Universal banks are referred to as those entities which apart from banking also combine insurance and/or investment banking either within the same organisation or through separately capitalised subsidiaries. Financial conglomerates, on the other hand, combine two of the three major activities, viz., banking, insurance and securities market within the organisation or through separately capitalised subsidiaries or holding company structure (see Chapter $\mathrm{X}$ for details).

[37]. Financial inclusions refer to the delivery of financial services to the masses and the vast section of the disadvantage and low income groups. 